\title{
DESCRIPTIONS OF A NEW GENUS AND FORTY-SIX NEW SPECIES OF CRUSTACEANS OF THE FAMILY GALA- THEIDA, WITH A LIST OF THE KNOWN MARINE SPECIES.
}

\author{
By James E. Benedict, \\ Assistant Curator of Marine Invertebrates.
}

The collection of Galatheids in the United States National Museum, upon which this paper is based, began with the first dredgings of the U. S. Fish Commission steamer Albatross in 1883, and has grown as that busy ship has had opportunity to dredge.

During the first period of its work many of the species taken were identical with those found by the U. S. Coast Survey steamer Blake, afterwards described by A. Milne-Edwards, and in addition several new species were collected. During the voyage of the Albatross to the Pacific Ocean through the Straits of Magellan interesting additions were made to the collection. Since then the greater part of the time spent by the Albatross at sea has been in Alaskan waters, where Galatheids do not seem to abound. However, occasional cruises elsewhere have greatly enriched the collection, notably three - one in the Gulf of California, one to the Galapagos Islands, and one to the coast of Japan and southward.

The U. S. National Museum has received a number of specimens from the Museum of Natural History, Paris, and also from the Indian Museum, Calcutta.

The literature of the deep-sea Galatheidæ from the nature of the case is not greatly scattered. The first considerable number of species were described by A. Milne-Edwards from dredgings made by the Blake in the West Indian region. Prof. S. I. Smith then described some interesting forms from the U. S. Fish Commission dredgings off the east coast of the United States. This was followed by the report of the Anomura of the voyage of the Challenger, by Prof. J. R. Henderson, which contained descriptions of many species of Galatheids from widely separated localities. In 1893 Dr. Faxon published preliminary descriptions of 24 new species from the Albatross expedition 
to the Galapagos Islands in 1891; also 38 species and subspecies dredged by the Indian survey ship Investigator since 1884 have been described by Wood-Mason or by Alcock and Anderson.

\section{Family GALATHEID A.}

The Galatheidæ, as has often been pointed out by recent writers; belong to the Macrura Anomalia, but with more or less brachyuran relationships.

In form they resemble the true Macrura, and are closely related to the Porcellanidæ, which at first sight, on account of their form and habits, would be placed with the Brachyura.

Most of the Galatheidæ live on the bottom and, with the exception of a few forms like Grimothea and Pleuroncodes, probably do not swim freely to any great distance. Some of the genera are blind, inhabiting deep water and even abyssal depths, others again have a well-developed cornea divided into facets. While many Galatheids must prefer a sea bottom affording numerous hiding places, others, as some of the genus Uroptychus, are well fitted for climbing on sponges, hydroids, or corals.

Occasionally a specimen will be found with a small worm tube on its carapace, though usually they are as completely free from any foreign growth as are any of the more active Crustacea. More frequently the carapace will be distorted by the presence of an Isopod parasite in the branchial chamber.

This family presents problems in classification of considerable interest. The genus Munidopsis, as now constituted and upheld by some good naturalists, is made to include several of the genera established by A. Milne-Edwards. In a long and able article ${ }^{a}$ on the subject, A. Milne-Edwards and E. L. Bouvier contend for the generic distinctness of the groups. With the groups united in one genus, the species differ widely in form, more widely than is desirable, because the name does not convey to the mind a sufficiently distinct picture of the forms designated by it. On the other side of the question it may be said that if the genera were divided a satisfactory key could not be made on generic lines unless perhaps in the case of Galathodes.

The species placed in the genus Munida come fairly well under one generic name, with the possible exception of one or more species sometimes placed under Grimothea, about which much has yet to be learned, especially in regard to the young forms, which do not seem to have the same development as the young of other species. Individual variations within the species are not uncommon. Sometimes the abdomen will be unarmed, where usually it is armed. This is more often true

a Considerations Generales sur La Famille des Galatheides, Ann. des Sci. Natr., (7), XVI, p. 191, 1894. 
in species having an armature of very small spines, as if chance conditions more easily pushed aside the less emphatic character. In old specimens of some species (and perhaps of all) the spines have a tendency to become blunted or even aborted, the chelipeds to become elongated, and the fingers to be separated by a hiatus. The relative lengths of the supraocular spines are as a rule uniform, and, in connection with others, furnish a very good character. The size and arrangement of the spines of the carapace and also of the abdomen, if armed, are important. Correlated with other characters, the width of the lines of the carapace, the length and character of the cilia, and the size of the granules are of value in determining species.

Some of the species in the U. S. National Museum are represented by but few specimens or even single individuals. In other cases the representation is greater. Large numbers of Munida iris A. MilneEdwards, were taken on the tile-fish grounds during the first year's work of the U. S. Fish Commission steamer Fish Hawk. So numerous in fact was this Munida that it gave character to the ground. Yet two years later, when the Albatross went over the same ground, the hauls of the beam trawl showed that this species, formerly so abundant, was wanting. Three degrees farther south, however, in latitude $37^{\circ}$ north, numerous specimens were found.

It will be remembered that the so-called tile-fish (Lopholatitus chamaeleonticeps Goode and Bean) was found abundantly during the year 1880, and that some time afterwards a vessel passed through miles of water covered with dead fish of this species. It was not again taken for a long time. The Fish Commission steamer Albatross dredged and set trawl lines on the ground time and again without taking either tile-fish or Munidas; and even farther south, where the Munidas were found in abundance, the fish were not to be had. It is interesting to note that the bottom Crustacea suffered at the same time and probably from the same cause.

Munida refulgens, $M$. tenella, and $M$. pusilla, species with elongated chelipeds, have, like $M$. iris, been found in large numbers, while $M$. subrugosa and $M$. quadrispina, are species with short prismatic chelipeds, and are represented in the collection by a smaller but yet plentiful number of specimens. Some interesting, though by no means novel, deductions may be drawn from the character and environment of some of the genera.

The mass of ova carried by the female Munida contains a very large number of individuals in comparison with some genera of the family living in much deeper water. To count the individuals in the egg mass of a Galathea or Munida would be a long task, while to count those of a Munidopsis, Galacantha, or Uroptychus would be a very easy matter. Some species of Uroptychus live in moderate depths that furnish innumerable hiding places. Here there is abundant protection 
for the individual. The natural inference is that the young individuals of the species having large eggs and few in number, do not encounter the dangers which must be common to the species having numerous eggs, and, as a matter of fact, it can hardly be supposed that a Galacantha or a Munidopsis, blind and with limited activity, passes an eventful life on the soft bottom of the deep sea.

Another matter worthy of consideration is that where the brood is small and matures near the parent it is not liable afterwards to become greatly scattered, a fact which would be expected to aid in the formation of races and species in the same way that it is known to have done in the cases of nonmigrating birds inhabiting islands or other isolated localities. And here it may be remarked that little is known of the range of any species in the deep sea. Only a beginning has been made. A dredging station here and there shows a few of the forms of life which the dredge chances to bring up from a very limited area. Until the sea bottom has been examined to a very much greater extent it would seem better to hold that distinguishable specimens from distant places represent distinct species rather than subspecies.

In sharp contrast with those Crustaceans which have few eggs and live under conditions where the individual must be better cared for are those having an immense number of eggs, as, for instance, some of the shallow-water Brachyura, in which the bulging egg-mass is but partly covered by the abdomen, and nearly equals the body of the crab in size. Here the eggs are minute and when hatched become free swimming and are carried by the currents to distant places to live or die, as the place proves suitable or not. This effort of nature is paralleled by the forest tree which yields seed, season after season, during a long lifetime and perhaps dies without leaving a single descendant. But if this effort has not greatly increased the individuals of the species in question, it has always been ready to do so if opportunity offered, and in the meantime has helped to sustain the life of myriads of other living things.

In this paper 45 species are described as new. The keys to the species were made to include all the Galatheids in the U. S. National Museum. Following the descriptions a list of the known species, with partial synonymy, has been given.

DESCRIPTIONS OF NEW SPECIES.

Genus GALATHEA Fabricius.

KEY TO THE SPECIES OF GALATHEA EXAMINED.

a. With only two spines or tubercles on the front of the gastric area.

b. Hands without spines except on the margins............... squamifera, p. 303

$b$. Hands with spines on the palm.

c. Three pairs of spines on the rostrum beyond the basal pair.

d. Row of four or five spines on the palm. 
e. Palm narrow.

$f$. Spines of rostrum weak .......................... andrewsi, p. 300

$f$. Spines of rostrum strong........................ intermedia, p. 302

d. Row of nine or ten spines on the palm of the hand ........ . orientalis, p. 302

c. Two pairs of spines on the rostrum beyond the basal pair.californiensis, p. 247

a. With more than two spines or spinules on the front of the gastric area or none.

$b$. With a row of spinules on the front of the gastric area.

c. Rostrum entire beyond the basal spines ................... integra, p. 248

c. Rostrum armed.

d. Lines on the carapace strong, elevated, few ............... rostrata, p. 303

d. Lines but little elevated, more numerous.............. . intermedia, p. 302

$b$. Without a row of spinules on the front of the gastric area.

c. Spines on the rostrum weak or none.

d. No spines on the rostrum beyond the basal pair........... agassizi, p. 300

d. With spines on the rostrum beyond the basal pair...... paucilineata, p. 249

c. Spines on the rostrum large................ dispersa and nexa, pp. 301, 302

GALATHEA CALIFORNIENSIS, new species.

The rostrum is more than twice as long as the eyes. It is armed with two pairs of stout spines. The sides of the rostrum are parallel

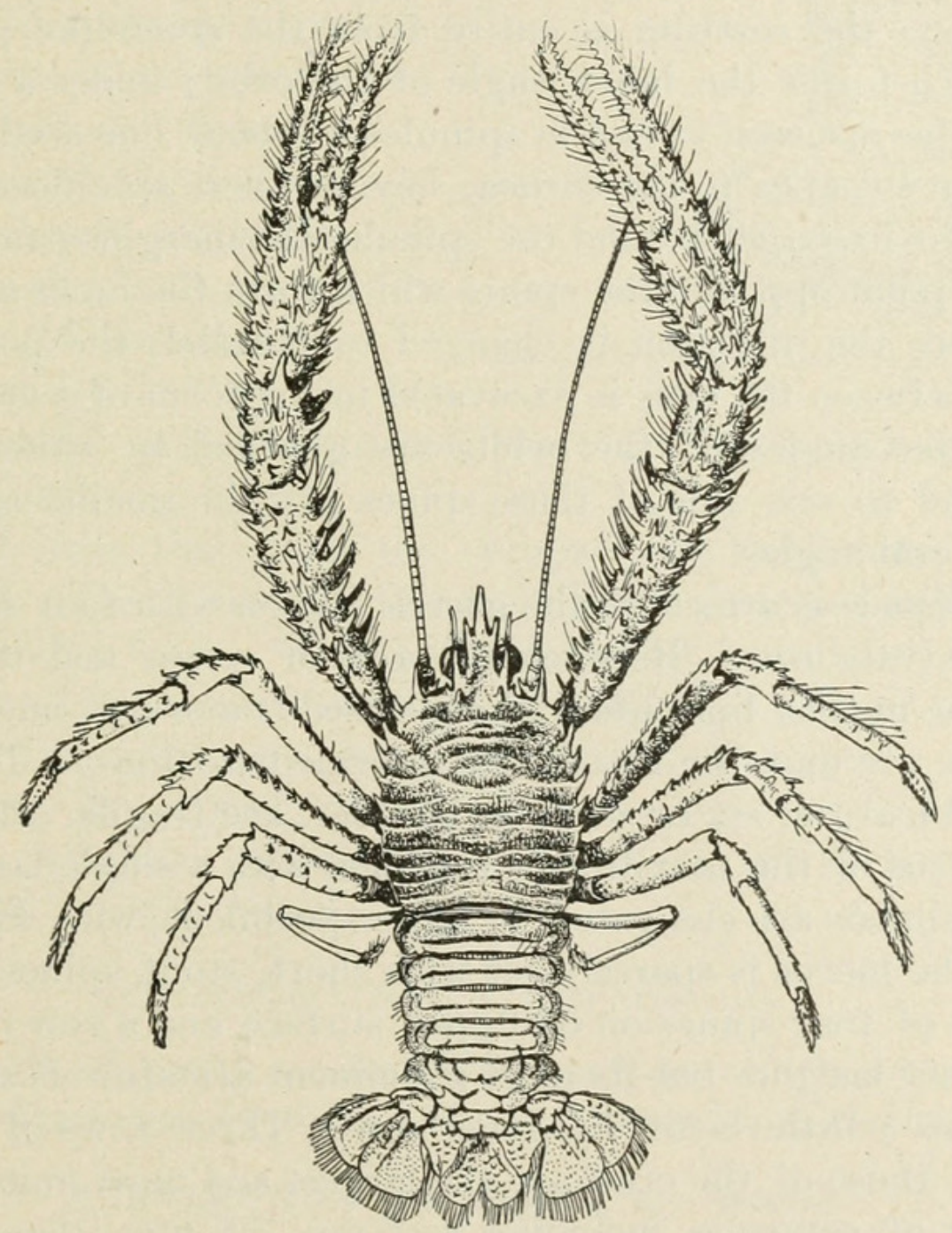

Fig. 1.-Galathea Californiensis, $\times \frac{7}{4}$.

between the spines. At the angle formed by the base of the rostrum and the front there is a pair of small spines. The carapace lacks but Little of being as broad as long; the transverse ridges are elevated and 
slightly set with hair. There are six spines on the margin behind the antennal spine. On the gastric region there is a pair of spines directly behind the posterior pair on the rostrum. The chelipeds are long and stout, very spiny and moderately hairy; the merus has five rows of spines; the carpus has three rows on its inner surface and four rows on its upper and outer surfaces; the outer surface of the palm has three rows of spines which are continuous with rows on the merus and carpus. The merus and carpus of the ambulatory legs are spiny; there is one row on the crest of the merus and two on the carpus; the propodus and dactyl are scabrus. The merus of the maxillipeds is armed with one long stout spine and one short one.

Length of a large male from the front to the end of the telson, 61 $\mathrm{mm}$.; length of cheliped, $100 \mathrm{~mm}$; length of merus, $38 \mathrm{~mm}$.

Locality.-Albatross station ${ }^{a} 2946$, lat. $33^{\circ} 58^{\prime}$ N.; long. $119^{\circ} 30^{\prime}$ $45^{\prime \prime} \mathrm{W}$.; depth, 150 fathoms.

Type.-Cat. No. 20551, U. S. N. M.

GALATHEA INTEGRA, new species.

To the eye the rostrum is entire from the spine-like point to the spine which forms the inner angle of the orbit; under a lens the lateral margins are seen to end in spinules at about one-sixth of the distance from the apex to the cornea; beyond these spinules the rostrum is spine like in shape; behind the spinules the margins run divergently back to a point opposite the spines which form the inner angles of the eyes, where the direction is changed to parallel; the portion of the rostrum between the eyes is excavated in the form of a very open $V$.

The outer angles of the orbits are guarded by spines. A little behind and to one side of these spines are the smaller spines of the antero-lateral angles.

The carapace is armed on the gastric region with four spines placed in a transverse row. Between this row of spines and the posterior margin the median line euts six long raised transverse lines. In addition there are more or less short, intermediate lines. The spines of the lateral margin, six or seven in number, are fragile, often wanting.

The merus of the maxillipeds is armed with a single large spine.

The chelipeds are elongated, in large specimens, with widely gaping fingers; the merus is sparsely set with short, stout spines; the carpus has a row of four spines on its upper surface and a row of five or six on the inner margin, but its most prominent armature is a single very large spine a little below the inner row. Three rows of spines arm the palm; those of the crest are the largest and most numerous.

Length of carapace, including rostrum, $7.5 \mathrm{~mm}$; length of cheli-

a A complete list of the dredging stations of the U. S. Fish Commission steamer Albatross, compiled by Mr. C. H. Townsend, will be found in U. S. Fish Commission Report for 1900, pp. 393-419. 
peds, $30 \mathrm{~mm}$. Taken from numerous stations off Honshu Island, Japan; the types are from Albatross station 3708, in 60 to 70 fathoms. Type.-Cat. No. 26168, U.S.N.M.

Galathea integrarostris Dana, resembles this species. It has a rostrum with margins unbroken by spines, but much shorter and broader in proportion to its other measurements. If Dana's figure is correct, the inner angle of the orbital sulcus is shaped by an incision of the rostrum which forms a broad tooth, which can not possibly be confounded with the sharp slender spine of $G$. integra.

GALATHEA PAUCILINEATA, new species.

The rostrum is rather narrow, with a few small spines on the sides; at the angle of the front and rostrum there are two short paired spines, which stand out well from the margin; those of the rostrum proper lie closely along the margin. On the front, above the insertion of the antennæ, there is a small paired spine;

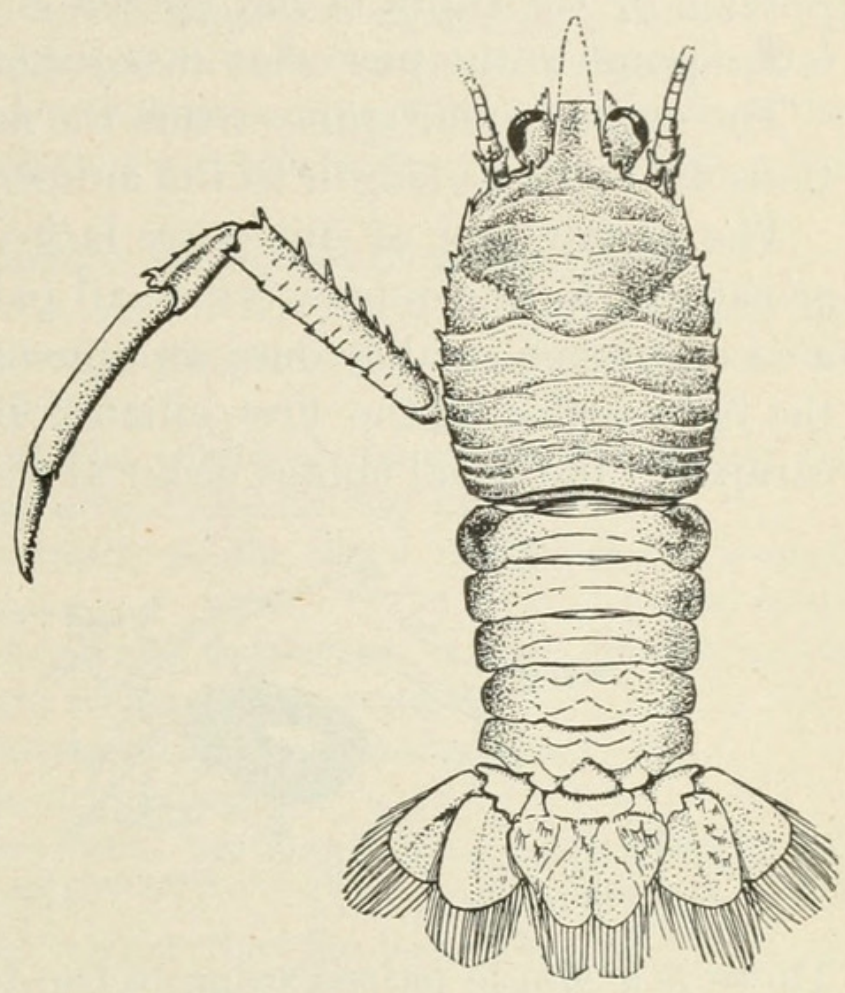

Fig. 2.-Galathea paucilineata, $\times 3_{4}^{\frac{1}{4}}$. the antero lateral angle is rounded; there are five or six spinules on the lateral margin.

The raised lines that cross the carapace are widely separated and little ciliated. The merus of the maxillipeds is armed with a single long and slender spine. The ambulatory feet are slightly spinulose on the crests of the meral and carpal joints.

Length of the carapace, $6 \mathrm{~mm}$.; breadth, $5.5 \mathrm{~mm}$.

Type.-Cat. No. 20552, U.S.N.M.

Locality.-Albatross station 2818 , latitude $00^{\circ} 29^{\prime} 00^{\prime \prime}$ S., longitude $89^{\circ} 54^{\prime} 30^{\prime \prime} \mathrm{W}$., in 392 fathoms.

\section{CERVIMUNIDA, new genus.}

Like Munida, but with a compressed rostrum which is arched so as to permit free movement of the eyes, and bears large teeth.

\section{CERVIMUNIDA PRINCEPS, new species.}

The rostrum in this species is armed with three sharp triangular teeth, two on the upper margin in advance of the eyes and one below and in advance of the upper ones; in addition to this armature one or 
more spinules are usually found between the apex and the two teeth above.

The direction of the rostrum is horizontal but opposite the eyes it forms an arch, resuming its horizontal direction beyond. In cross section the rostrum is triangular with the short side below, the lower margins are carinate, the carina running around to the supra-ocular spines; the length of the rostrum from the tip to the base of the free portion of the supra-ocular spines is equal to the distance from the latter point to the posterior margin of the gastric region.

The supra-ocular spines reach the middle of the eyes; their free portions are equal in length to the antero-lateral spines.

The gastric pair of spines are large and sharp with no intermediate armature; in line outside is a small paired spine and in some specimens a second much smaller one; an unusual spine in the gastric area is at the intersection of the first ciliated line with the median line of the carapace; the usual spines occur at the extremities of the ciliated line.

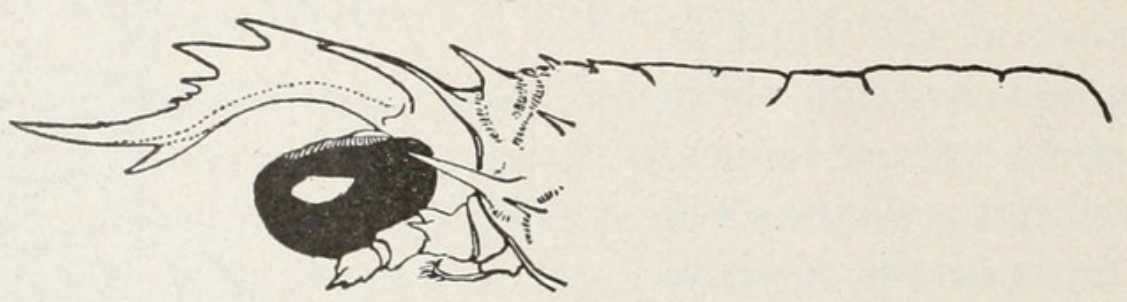

Fig. 3.-CERVIMUNID $\div$ PRINCEPS, $\times 2$.

There is a single paired spine in the fork of the suture and one in the usual place just behind the suture. The lower margin of the merus of the maxillipeds has a spine at each extremity.

The chelipeds are elongated; spines are scattered over the merus and carpus; the fingers are longer than the ridge of the palm; the movable finger is armed with a row of spines on the inner surface just below the ridge; numerous small spines are scattered over all surfaces of the palm, except the lower; the chelipeds are hairy in the large specimens; the ambulatory legs are squamose and hairy.

The abdomen is armed. The 12 specimens examined show for the most part eight spines on the second and fourth segments; the third segment shows six, seven, or eight spines, but usually six; in the other segments the number of spines also varies but not so frequently.

The length of the largest specimen examined is $147 \mathrm{~mm}$., carapace, from the base of the rostrum, $27 \mathrm{~mm}$; chelipeds, $102 \mathrm{~mm}$.

Type.-Cat. No. 25464, U.S.N.M., from Albatross station 3698, in 153 fathoms off Honshu Island, Japan. 


\section{Genus MUNIDA Leach.}

KEY TO THE SPECIES OF THE GENUS MUNIDA EXAMINED.

1. Abdomen unarmed.

a. Rostrum with several lateral spines near the apex ......... . refulgens, p. 312 a. Rostrum without spines at apex.

b. Palm much shorter than the fingers .................. mexicana, p. 264

$b$. Palm ranging from a trifle shorter to much longer than the fingers.

c. Palm and fingers subcylindrical.

d. No spines posterior to the middle transverse depression . simplex, p. 272

d. With spines posterior to the middle of the transverse depression.

e. Supraocular spines not reaching the middle of the eyes _deblis, p. 256

e. Supraocular spines reaching the middle of the eye..... .irrasa, p. 310

c. Palm and fingers flattened.

d. With several spines posterior to the middle transverse depres-

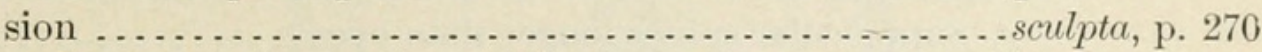

d. No spines posterior to the middle depression....... quadrispina, p. 269

2. Second segment of the abdomen armed.

a. Chelipeds more than four times the length of the carapace, including the rostrum; palms subcylindrical, armed with but few spinules.

$b$. Suprancular spines, reaching nearly to the distal margin of the cornea.

iris, p. 310

b. Supraocular spines, short, not reaching the cornea .......... pusilla, p. 268

a. Chelipeds less than four times the length of the carapace.

$b$. Gastric spines, with two or three small intermediate spines.

c. Cornea but little larger than the peduncle.

d. Merus of maxillipeds armed with one spine .......... perlata, p. 266

d. Merus armed with two spines ................ microphthalma, p. 311

$c$. Cornea wide, spreading; much larger than the peduncle.

$d$. No spines on the margins of the fingers.

e. Fingers three times length of palm .................. curvamana, p. 307

$e$. Fingers not three times the length of palm.

$f$. Rostrum cutlass-shaped, elevated to an angle of 45 degrees above line of carapace ........................... . . . . . . . . 253

f. Rostrum sigmoid, horizontal................ andamanica, p. 306

$d$. With spines on the margins of the fingers.

e. Supraocular spines, reaching beyond the eyes......propinqua, p. 312

$e$. Supraocular spines not reaching beyond the eyes.

$f$. Fingers straight.

g. Spines in the gastric row, six.

h. One spine in the triangular area .......... sancti-pauli, p. 312

$h$. No spines in the triangular area ............. decora, p. 257

g. Spines in the gastric row, twelve ............honshuensis, p. 261

f. Fingers curved .................................... . . . 254

$b$. No intermediate spines.

c. Fingers much longer than the palm ................. forceps, p. 307

c. Fingers shorter than the palm.

d. Hand bent downward at the base of the fingers, all surfaces spinu-

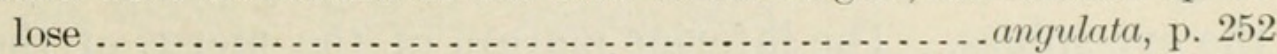

d. Hand not bent, broad, spinulose on outer surface and margins. nuda, p. 265

3. Second and third segments of the abdomen armed.

a. A pair of spines between the large gastric pair.

b. Without spines behind the cervical suture. (See 2 above) . . decora, p. 257

b. With spines behind the cervical suture .................. obesa, p. 311

Proc. N. M. vol. xxvi $-02-18$ 
a. Without spines between the large gastric pair.

b. With a pair of spines near the middle of the gastric region ... . valida, p. 314

b. Without middle gastric spines ........................ media, p. 262

4. Second, third, and fourth segments of the abdomen armed.

a. Posterior margin of the carapace armed. $a$

$b$. Spines of the posterior margin more than two.

c. With spines on the cardiac region.

d. Cardiac spines one only ......................... evermanni, p. 307

d. Cardiac spines more than one.

e. Cardiac spines one pair . . . . . . . . . . . . . . . . . perarmata, p. 311

e. Cardiac spines in two rows ......................... hispida, p. 259

c. Without spines on the cardiac region ................ bamffica, p. 306

$b$. Spines on the posterior margin one or two.

c. Fourth segment of the abdomen with a pair of spines on the anterior margin and a single spine on the median line near the posterior margin.

d. Spines on the middle of the gastric region one or more.

e. Supraocular spines longer than eyes . .................. affinis, p. 305

e. Supraocular spines shorter than eyes ................. flinti, p. 258

d. Without spines in the middle of the gastric region.

e. With a row of spines on each side of the cardiac region . normani, p. 311

e. Without rows of spines on the branchial region near the cardiac

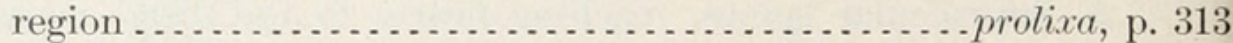

c. Fourth segment of the abdomen without median spine.

d. Supraocular spines longer than the rostral spine........ longipes, p. 310

d. Supraocular spines not longer than the rostral spine.... stimpsoni, p. 313

a. Posterior margin of the carapace unarmed.

b. Chelipeds long and slender; merus cylindrical............. tenella, p. 274

$b$. Chelipeds short and stout; merus prismatic.

c. Two or more spines on the outer margins of both fingers of the chelipeds . . . . . . . . . . . . 307

c. No spines on the outer margins of the fingers.

d. Merus of the maxillipeds unarmed.

e. Eyes produced beyond the line of the sides.... gregaria, young, p. 308

e. Eyes not produced beyond the line of the sides ...... gregaria, p. 308

d. Merus of the maxillipeds armed .................... subrugosa, p. 314

MUNIDA ANGULATA, new species.

The carapace is broadest a little behind the middle. The gastric region has eight spines, six of which are in a line behind the front. These spines are subequal in size. A single spine is placed on the side near the margin of the hepatic area; single spines on the anterior branchial regions are the only other spines on the carapace, excepting those of the lateral margins. The supraocular spines are about onehalf the length of the eyes. The rostrum is moderately long and nearly horizontal. The peduncles of the eyes are stout and a little longer than usual; the cornea is less dilated. The front retreats from the eye spines. The inferior margin of the merus of the maxillipeds is armed with two spines. The chelipeds are spiny and spinulose; the fingers are cylindrical and in all specimens examined are in contact

a Occasional specimens found with posterior margin of carapace unarmed. 
throughout the length of their prehensile edges. A striking character of this species is the shape of the hand, which is bent downward from the base of the fingers. A row of from two to six spinuies arms the second segment of the abdomen; in some specimens the armature is wanting.

Length of the abdomen, $9 \mathrm{~mm}$; length of chelipeds, $20 \mathrm{~mm}$.; length of palm, $5.5 \mathrm{~mm}$.; length of fingers, $4 \mathrm{~mm}$.

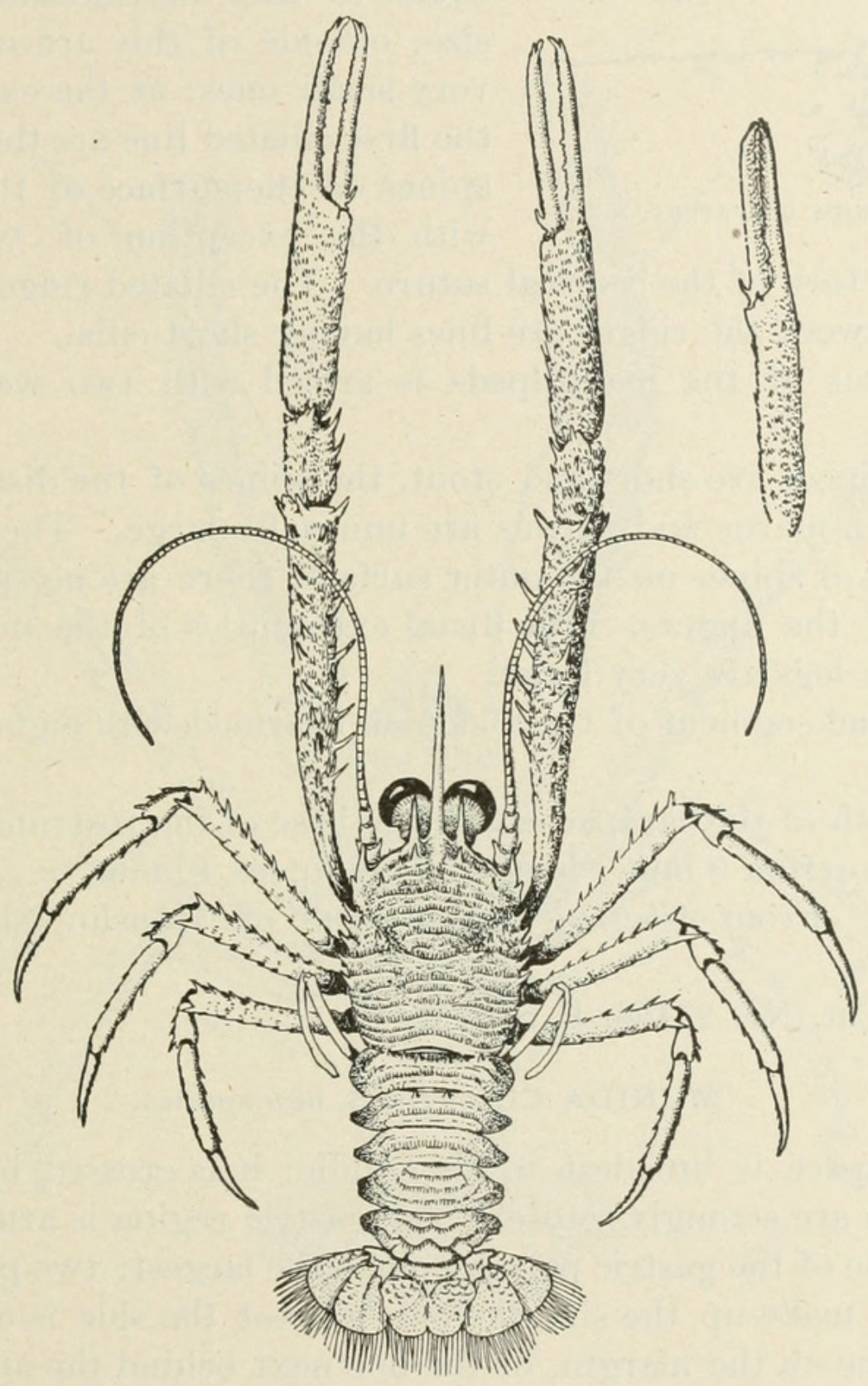

Fig. 4.-MUNidA ANGUlata, $\times 4$.

Locality.-Albatross stations 2370, 2372, 2406, 2411, 2413, in 25, $27,26,27$, and 24 fathoms.

Type.-Cat. No. 20532, U.S.N.M., station 2406.

\section{MUNIDA CURVATURA, new species.}

The rostrum is long, sharp, and a little compressed, beginning at its base it curves rapidly upward, so that at its tip its direction is 45 degrees from the line of the carapace. The supraocular spines 
diverge but iittle, they extend forward nearly to the extremity of the eyes.

The eyes are large with a brown iris, which has small, but distinct facets.

The carapace is broadest at about the anterior third, the gastric pair of spines are large, a pair of much smaller spines are intermediate,

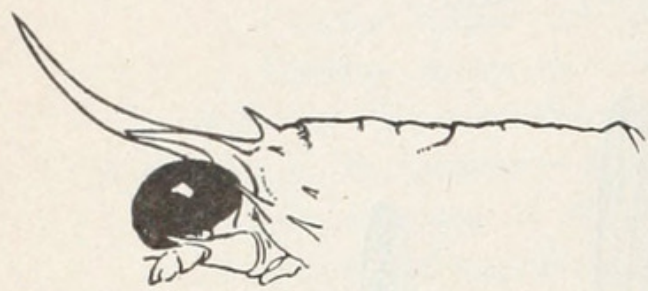

Fig. 5.-Munida CURVATURA, $\times 2$. outside of the pair is a paired spine, equal to the intermediate spines in size; outside of this are one or more very small ones; at the extremities of the first ciliated line are the only other spines on the surface of the carapace, with the exception of two spinules behind the fork of the cervical suture. The ciliated ridges are rather coarse; between the ridges are lines having short cilia.

The merus of the maxillipeds is armed with two well-separated spines.

The chelipeds are short and stout, the spines of the distal extremities of both merus and carpus are unusually large. The palms have three rows of spines on the outer surface, there are no spines on the margins of the fingers. The distal extremities of the merus of the ambulatory legs are very large.

The second segment of the abdomen is armed with eight good-sized spines.

The length of the carapace from the base of the rostrum is $17 \mathrm{~mm}$.: length of rostrum $9 \mathrm{~mm}$.; length of chelipeds $40 \mathrm{~mm}$.

Locality.-From Albatross station 3698, off Honshu Island, Japan, 153 fathoms.

Type.-Cat. No. 25466, U.S.N.M.

MUNIDA CURVIPES, new species.

The carapace is broadest in the middle; it is crossed by numerous striæ which are strongly setose. The gastric region is armed with six spines, those of the gastric pair are much the largest; two paired spines at the side make up the six; the one nearest the side is opposite the second spine on the margin, or the one next behind the antero-latera spine. Between the gastric spines are three granules, one of which has a sharp point to be seen only with a lens. Three spiny granule are situated close to and behind the gastric pair. The greater part $o$ the rostrum is unfortunately lost; the supraocular spines reach the end of the cornea. The peduncle of the antennæ is armed as in Munide spinosa Henderson, with the exception of the terminal article wher the spine is so small that it can not be made out except under a lens The eyes are much smaller than in many species of the genus. Thi merus of the maxillipeds is armed with two long spines; the margil 
between them is straight and not at all as shown in the figure of $M$. spinosa. The chelipeds are long and rather slender, armed with slender spines placed for the most part in rows; there are about eighteen spines on the merus, large and small; the carpus has at least an equal number; there are four rows of spines on the palm; the fingers of the left hand are unarmed; those of the right are both armed.

The second segment of the abdomen is armed with six spines, which nearly equal the gastric pair in size; the other segments of the abdomen are smooth.

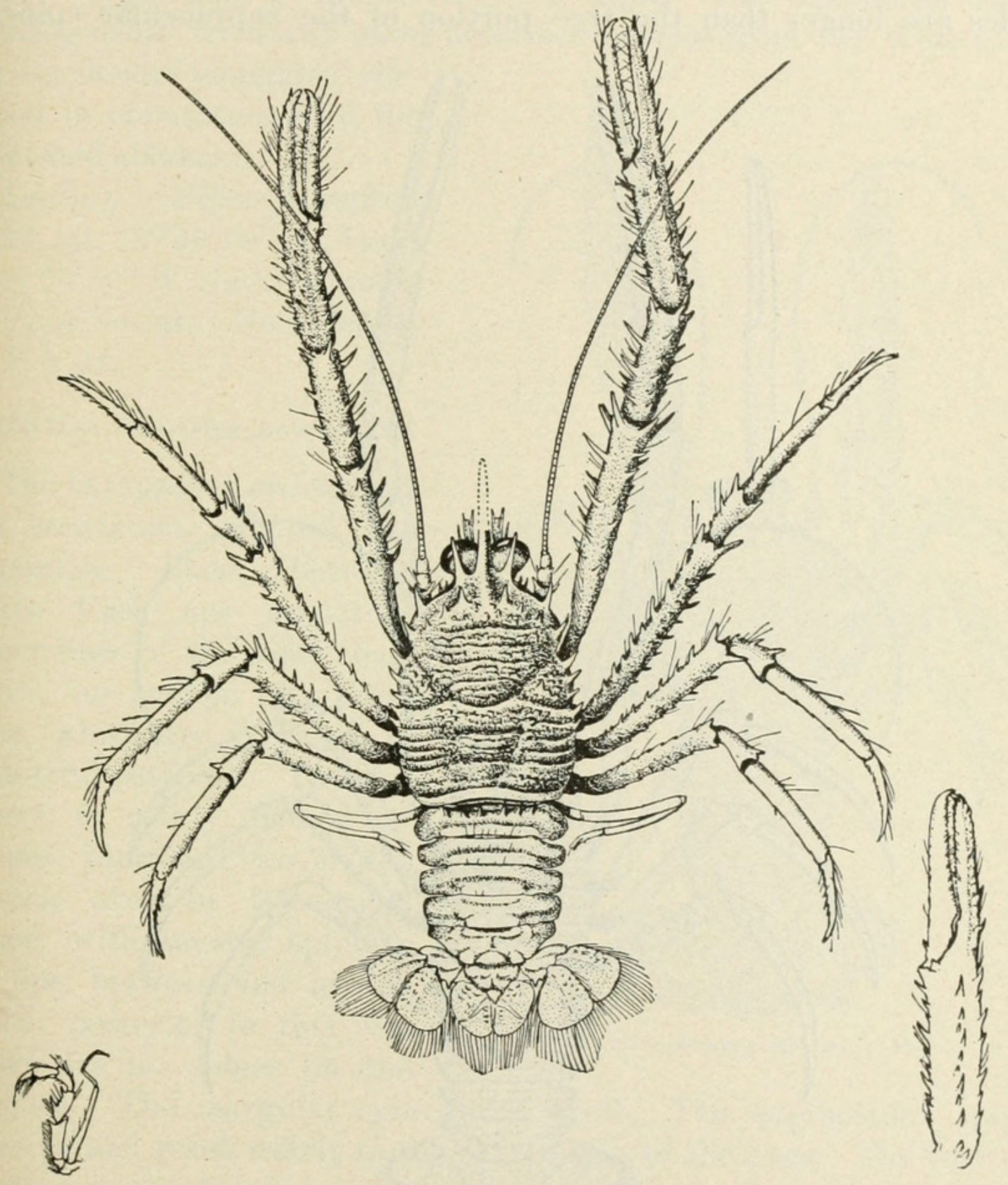

Fig. 6.-MUNiDA CURVIPES, $\times 1$.

This species is closely related to Munida spinosa Henderson. It is separated by the lines of the carapace, which are not so strong, by the different shape of the pleura of the abdominal segments, and if the Challenger figure is correct, the merus of the maxillipeds is very different. ${ }^{a}$

${ }^{a}$ Challenger Report, Anomura, J. R. Henderson, XXVII, 1888, p. 128, pl. III, fig. 3 , a, b. 
Measurements.-Length of specimen from the base of the free part of the rostrum to the end of the telson $30 \mathrm{~mm}$.; length of the cheliped $40 \mathrm{~mm}$; palm $10 \mathrm{~mm}$; fingers, $8 \mathrm{~mm}$.

Locality.-Albatross station 2788, off Port Otway, Patagonia, in 1,050 fathoms.

Type.-Cat. No. 20533, U.S.N.M.

MUNIDA DEBILIS, new species.

The carapace is broad in front; the spines of the antero-lateral angles are longer than the free portion of the supraocular spines.

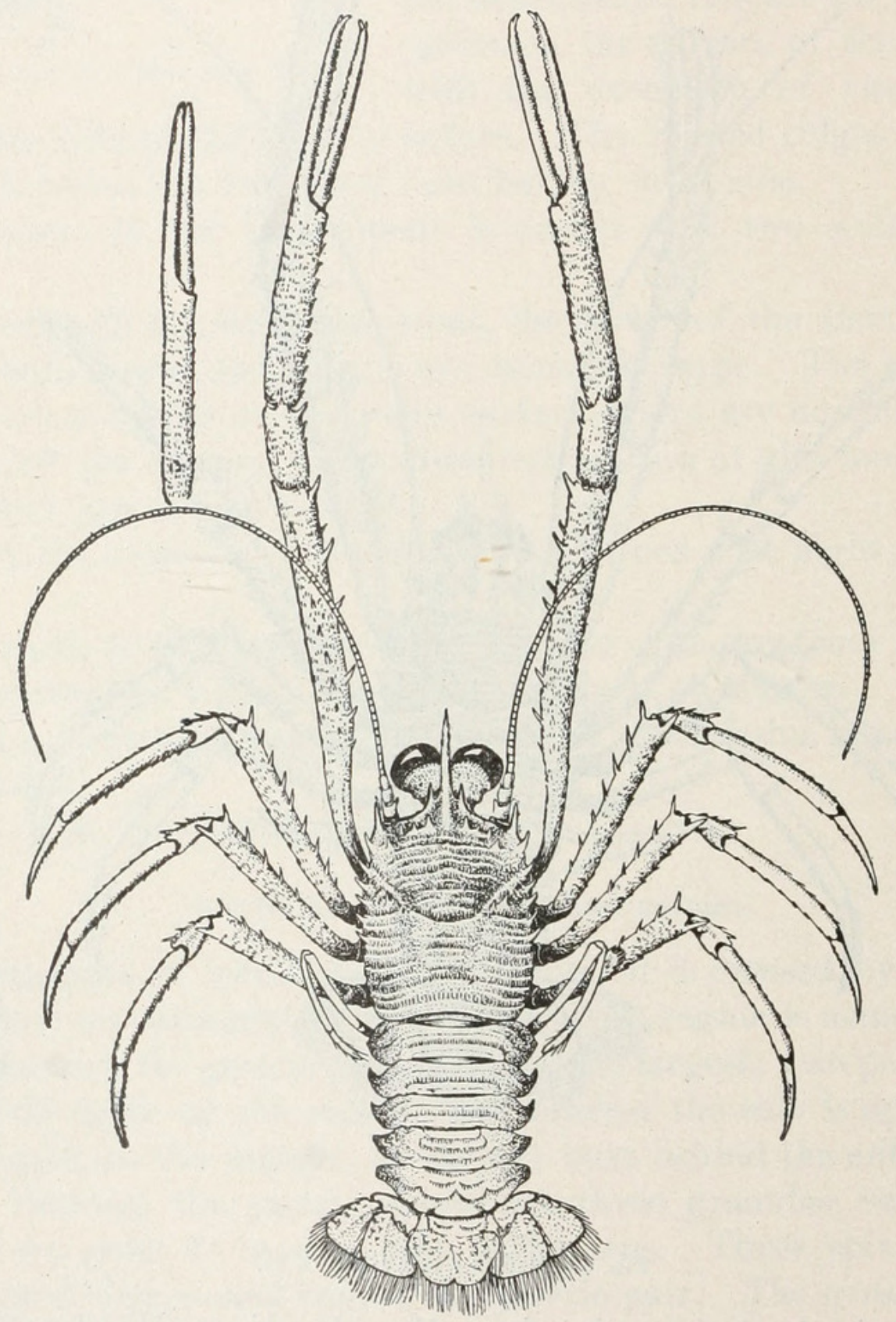

Fig. 7.-MUNidA DeBILIS, $\times 4$.

There is a row of eight spines on the front of the gastric area and a spine at the extremities of the first continuous ciliated line. Between this line and the gastric row is a ciliated line interrupted at the median line by a semicircle of the same character. 
The rostrum is long and slender; the lateral margins are denticulated near the apex; the supraocular spines are united to the rostrum for one half their length. The peduncles of the eyes are short and the cornea very much dilated. The inferior margin of the merus of the maxillipeds is armed with three spines, two on the proximal half and one on the distal angle. The chelipeds are long, slender, cylindrical, and scabrous; the inner margin of the merus is armed with about six large spines; there are three on the upper surface; the carpus has a single large spine at the distal inner angle. This species is easily distinguished from any other described species from the West Coast by its slender elongated cheliped in connection with the unarmed abdomen.

Locality.-Albatross station 2829 , lat. $22^{\circ} 52^{\prime} 00^{\prime \prime} \mathrm{N}$., long. $109^{\circ} 55^{\prime} 00^{\prime \prime} \mathrm{W}$., in 31 fathoms.

Type.-Cat. No. 20534, U.S.N.M.

MUNIDA DECORA, new species.

The carapace is crossed by six continuous ciliated and granulose lines; between these lines are numerous other lines of the same character, but broken into small ares, which are arranged in beautiful patterns. The carapace is nearly devoid of spines; there are two on the gastric area in the usual place, with several spinules in line between and at the sides; posterior to this row there are no spines on the
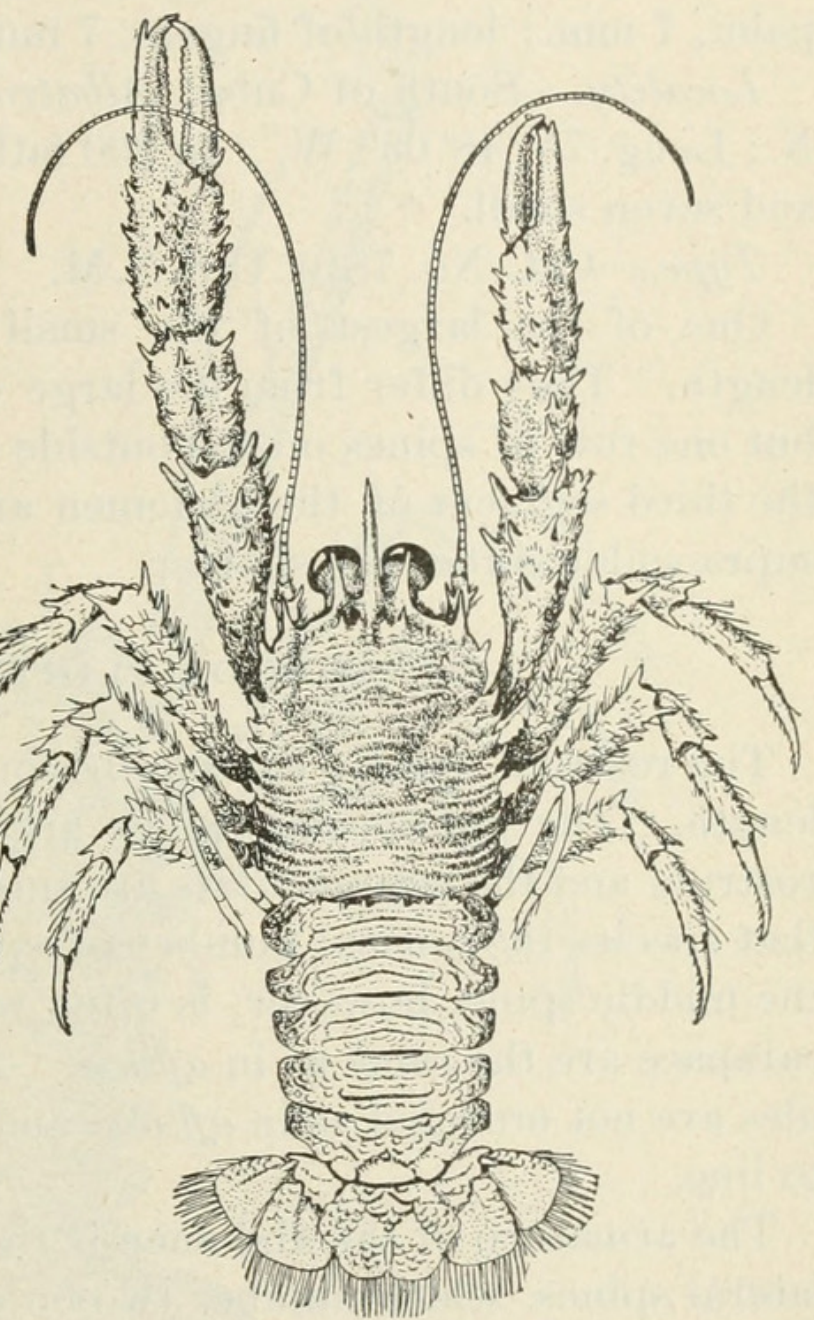

FIG. 8.-MUNIDA DECORA, $\times 1 \frac{1}{2}$.

surface. The marginal spines are small. The supraocular spines diverge and reach nearly to the extremities of the eyes. The rostrum is strong-about twice as strong as the supraoculars - and is serrate near the end, above and below, and on the sides. The peduncles of the eyes are very short and much constricted; the cornea is dilated at the sides. The inferior margin of the merus of the maxillipeds is armed with two large and widely separated spines, between which are one or more spinules.

The chelipeds are broad, flattened, and hairy. The spines of the 
distal margin of the merus are large; those of the carpus are smaller. There are four rows of spines on the palm - one on each margin and two on the surface behind the gape of the fingers; there are also two spines on the crest of the palm, in a parallel line with the marginal row; a single spine is placed near the middle of the inside of the palm; the inside surface is roughened by numerous spiny granules.

The ambulatory feet are compressed and moderately spinose. The abdomen has a line of spines on the second segment.

The specimen described is a female measuring $33 \mathrm{~mm}$. from the front to the end of the telson; length of larger cheliped, $39 \mathrm{~mm}$.; length of palm, $7 \mathrm{~mm}$.; length of fingers, $7 \mathrm{~mm}$.

Locality. - South of Cuba; Albatross station 2133 . Lat. $19^{\circ} 55^{\prime} 55^{\prime \prime}$ N.; Long. $75^{\circ} 48^{\prime} 03^{\prime \prime} \mathrm{W}$. In 290 fathoms; eight specimens, one large and seven small.

Type--Cat. No. 7810, U.S.N.M.

One of the largest of the small specimens measures $17 \mathrm{~mm}$. in length. They differ from the large one taken for the type in having but one row of spines on the outside of the palm and several in having the third segment of the abdomen armed with only two spines. The supraocular spines are shorter.

\section{MUNIDA FLINTI, new species.}

The rostrum usually extends beyond the eyes about one-half of its length. The supraocular spines are shorter than the eyes, both the rostrum and the supraoculars are smoother than in $M$. affinis. As in that species the normal number of spines on the gastric area is seven, the middle spine, however, is often wanting, the other spines of the carapace are the same as in affinis. The tranverse lines and the granules are not crowded as in affinis, and the cilia do not reach from line to line.

The armature of the abdomen is the same as in affinis except in the lateral spines, which number two on each side of the central pair on the second segment and but one on the third segment, while the fourth segment has only the central pair and a single posterior spine on the median line. The chelipeds are scabrous and spiny; the merus has about fourteen spines on or near the crest, and here and there a single spine on other parts of the surface. The palm of the hand is densely scabrous, the spinules are few and scattered. The dactyl has a row of widely separated spinules on its margin. The prehensile edges of the fingers are set with hair and armed with well separated teeth; between the teeth the edge is crowded with denticles.

This species is much like affinis and stimpsoni in general appearance, but very different from either in detail. Named for Dr. J. M. 
Flint, U. S. Navy, surgeon on the U. S. Fish Commission steamer Albatross.

All the specimens were taken by the Albatross during a cruise in the northern part of the Gulf of Mexico.

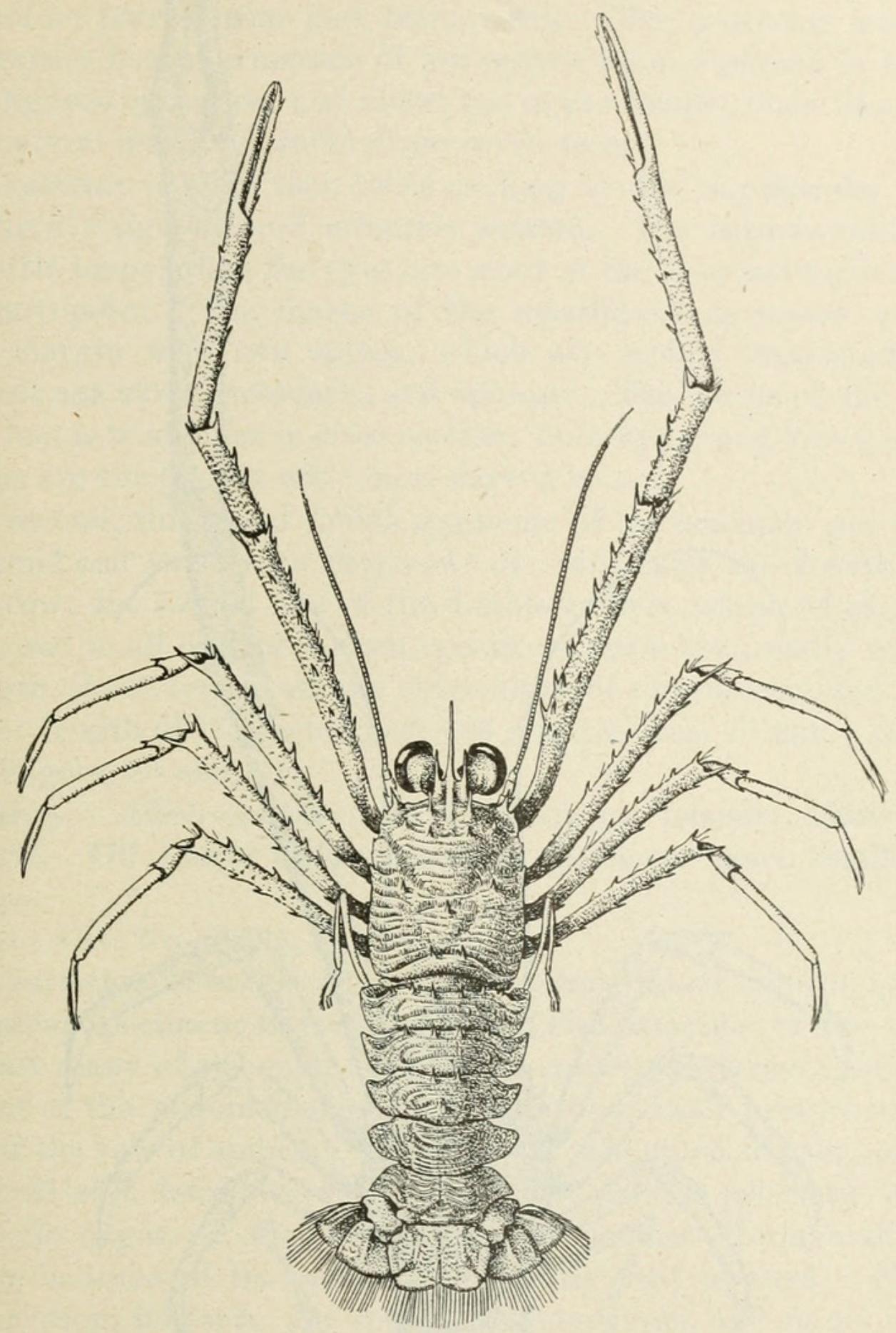

Fig. 9.-MUNidA FLINTI, $\times 2$.

Locality.-Albatross station 2402 in 111 fathoms, two specimens; station 2403 in 88 fathoms; station 2404 in 60 fathoms, eleven specimens.

Type-Cat. No. 9778, U.S.N.M.

MUNIDA HISPIDA, new species.

The carapace is broadest at about the posterior third; the breadth at the posterior margin is greater than the front. The front is flattened, almost transverse between the supraocular spines and the 
spine behind the antennæ. The transverse lines are strong, granulose, and sometimes spinulose.

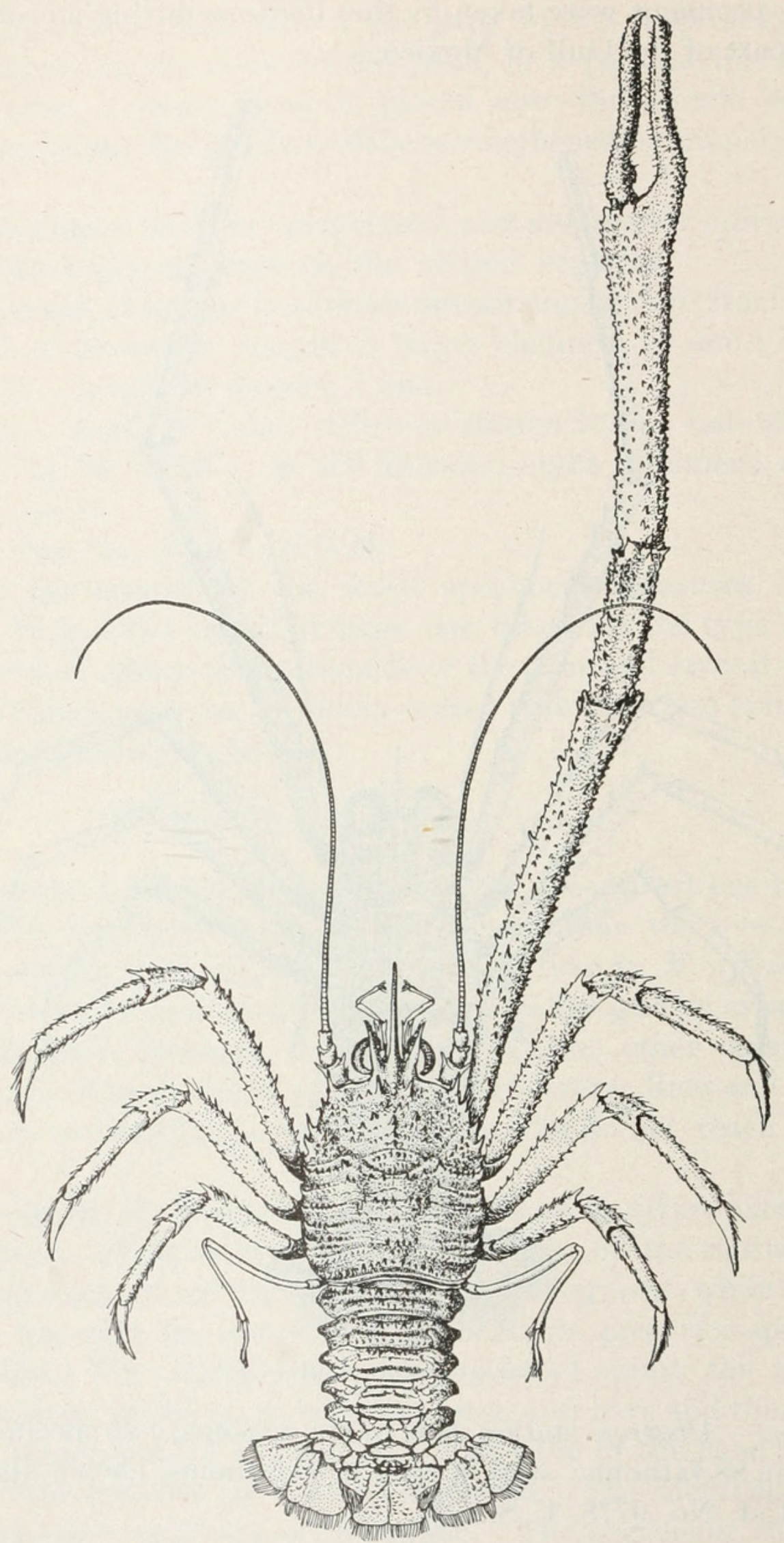

FIG. 10.-MUNIDA HISPIDA, $\times \frac{3}{5}$.

The gastric spines are small; a much smaller pair is placed in advance and a little closer together. On the median line of the gastric region there are five or six spines, and on a ridge behind these there is a row 
of spinules; at the side there are two spines obliquely placed; a number of spinules are scattered over the anterior portion and sides of this area. There are about sixteen spinules on the triangular area; a spine on the branchial area just behind the apex of the triangle, and another paired spine just behind this. The posterior border of the carapace has an armature of low spines about eighteen in number in the figured specimen, and about ten in the smaller ones; the spines of the lateral margin number from seven to ten.

The rostrum is more than twice as long as the supraocular spines; it is slightly sigmoid and minutely serrate. The supraocular spines are a little longer than the eyes, are stout at the base and taper rapidly to a sharp point. The merus of the maxillipeds is armed on its inferior margin with two spines, which are widely separated. The chelipeds are stout, prismatic, and spinose. The merus of the ambulatory feet is triangular in cross section; both upper and lower anterior margins are thickly set with short curved spines.

The second, third, and fourth segments of the abdomen are armed, the second and third with two rows of spines and the fourth with a single row; the second row of the double rows is composed of smaller spines, and in all but the largest specimens these are usually wanting.

Length of the type from the extremities of the rostrum and telson, $83 \mathrm{~mm}$.; length of right cheliped, $186 \mathrm{~mm}$.; merus, $70 \mathrm{~mm}$.; palm, 53 $\mathrm{mm}$.; fingers, $30 \mathrm{~mm}$.

Locality.-Albatross station 2817, Galapagos Islands; Albatross station 2987. Off Lower California seven specimens much smaller than the type.

Type.-Cat. No. 20535, U.S.N.M.

The variation between the large specimen taken for the type and the smaller specimens is considerable. The carapace of the smaller ones lack many of the spinules, and the spines are larger; the fourth segment of the abdomen may show only two small protuberances in place of the row of spines. The chelipeds are much shorter, and they are armed with definite rows of spines; the palm is prismatic, and the prehensile edges of the fingers are in contact throughout. The rostrum in some of the smallest is slightly bent upward. With all this variation, however, the specimens intergrade, and in my opinion give no ground for separation.

MUNIDA HONSHUENSIS, new species.

The rostrum is slightly sigmoid, and is more than twice the length of the supraocular spines, which do not quite reach the cornea.

The spines of the gastric area are sixteen in number-twelve in the gastric row, a pair separated by the first ciliated line, and a paired spine at the base of the antero-lateral spine; there is a single paired spine in the fork of the cervical suture and one back of the fork. 
The spines of the merus of the maxillipeds are large and situated at the extremes of the segment.

The chelipeds are short, stout, and prismatic; the spines of the distal portion of the merus are very large, becoming smaller proximally.

There are four rows of spines on the carpus. The largest occupy the crest, the smallest the row on the outer surface near the lower margin. Medium-sized spines occupy the rows that arm the inner and outer surfaces. The outer margins of the fingers are each armed with four rather large spines.

The second segment of the abdomen is armed with nine spines, which are short and blunt.

The length of the carapace from the end of the rostrum is $16 \mathrm{~mm}$; length of chelipeds, $26 \mathrm{~mm}$.

One specimen, female, from Albatross, station 3708, in 60 to 70 fathoms, off Honshu Island, Japan.

\section{Type. Cat. No. 25472, U.S.N.M.}

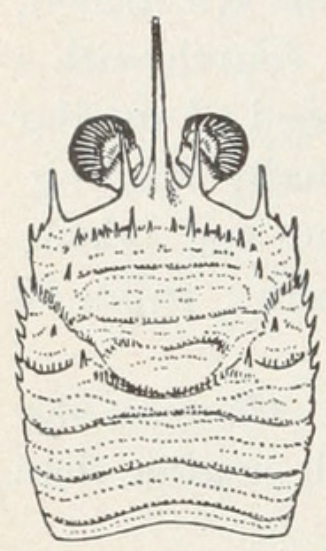

FIG. 11. - M UNIDA HONSHUENSIS,

This species is an addition to the group of which Munida militaris Henderson is the typical example. It differs in not having spines on the median line of the carapace and in its shorter and less divergent supraoculars.

The hands of this species are compressed, the outline of the palms is straight, and not as shown in the figure of $M$. militaris in the Challenger report; the outer surface of the palms is made up of two planes which intersect at the median row of spines.

Two males were taken at station 3739 in 55 to 65 fathoms, which differ from the specimen taken as the type in that the chelipeds are elongated, and are without any prominent spines, there are numerous small spines on the nerus and carpus, a few on the palm, and one or two on the margins of the fingers. There is a hiatus between the fingers, the prehensile edges of which are set with small teeth even in size and with roun'ed ends; the hiatus which extends the length of the fingers is filled with bristles which arise from the lower surface of both fingers.

\section{MUNIDA MEDIA, new species.}

The carapace is widest in the middle; the sides are arcuate, the anterior portion is armed with six or seven spinules.

The transverse striæ are not crowded; are both granulated and ciliated; the cilia are iridescent. The postocular or gastric spines are small; a much smaller paired spine stands at the side in line with them; another paired spine is placed farther down near the hepatic region. The cervical groove is deep; where it meets the side there is a notch; the cilia in both branches are longer than elsewhere. The triangular 
areolation in the fork of the groove is armed with five or six spinules. There are also several spinules on the anterior border of the branchial region. The posterior border of the carapace is unarmed.

The rostrum is slender and elongated, equaling in length the width of the carapace; the supraocular spines are short, not reaching the distal extremity of the cornea. The inferior border of the merus of maxillipeds is armed with three slender spines graded in size, the proximal being the longest.

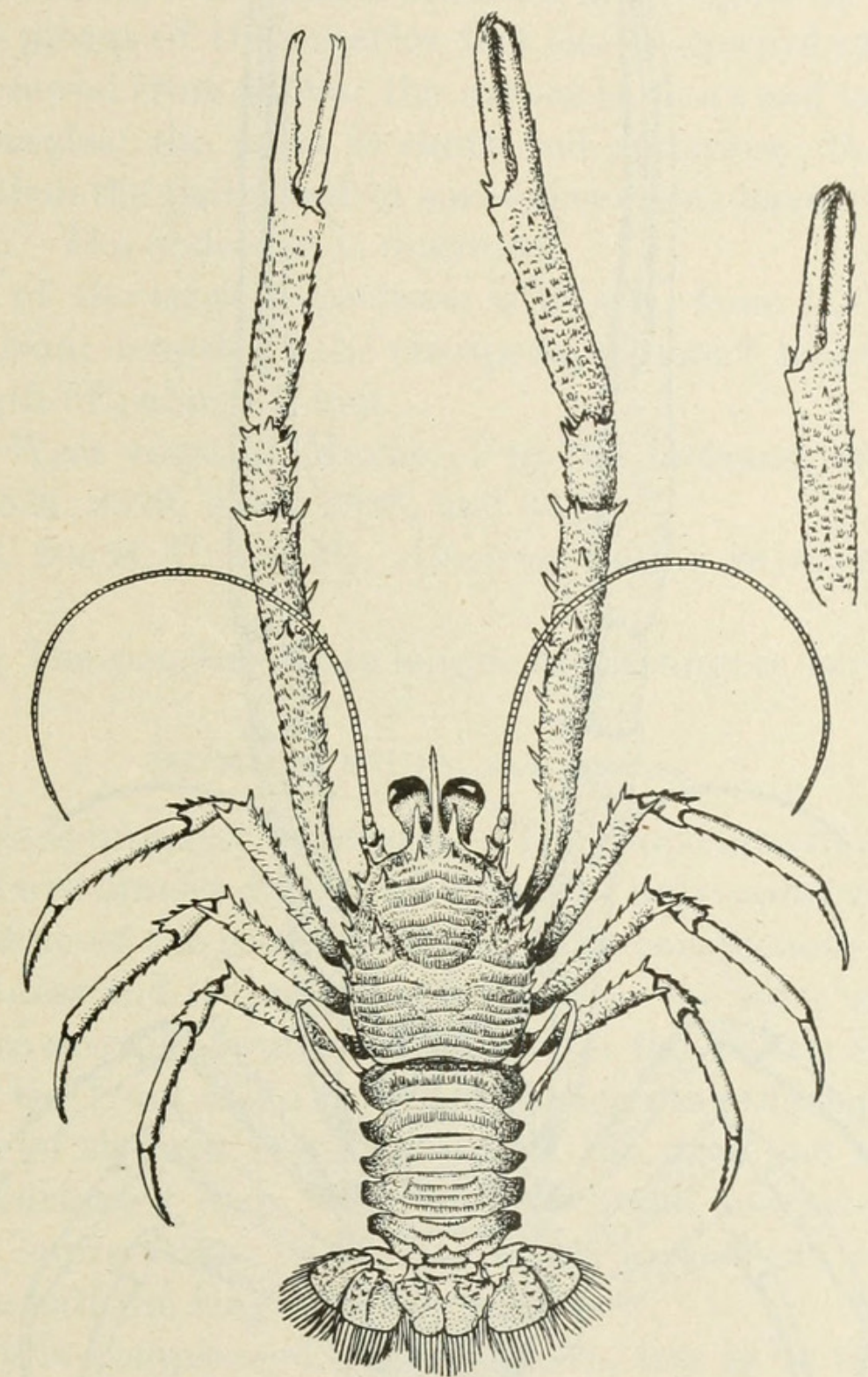

Fig. 12.-MUNIDA MEdIA, $\times 4$.

The eyes are large with spreading cornea.

The chelipeds are long, slender, and subcylindrical; the merus and carpus are armed with slender spines, the palm with spinules.

The merus of the ambulatory legs has a row of spines on the upper margin; in line with these there are five or six on the carpus; the lower margin of the propodus has a row of seven spinules.

The second segment of the abdomen has a row of eight small spines and the third segment a single pair. The other segments are smooth. 
The length of the body from the front to the end of the telson is $10 \mathrm{~mm}$.; length of the chelipeds, $24 \mathrm{~mm}$.; length of the palm, $5 \mathrm{~mm}$.; length of the fingers, $4.3 \mathrm{~mm}$.

Locality.-Off Habana, Albatross station 2343, 279 fathoms. Type.-Cat. No. 9524, U.S.N.M.

MUNIDA MEXICANA, new species

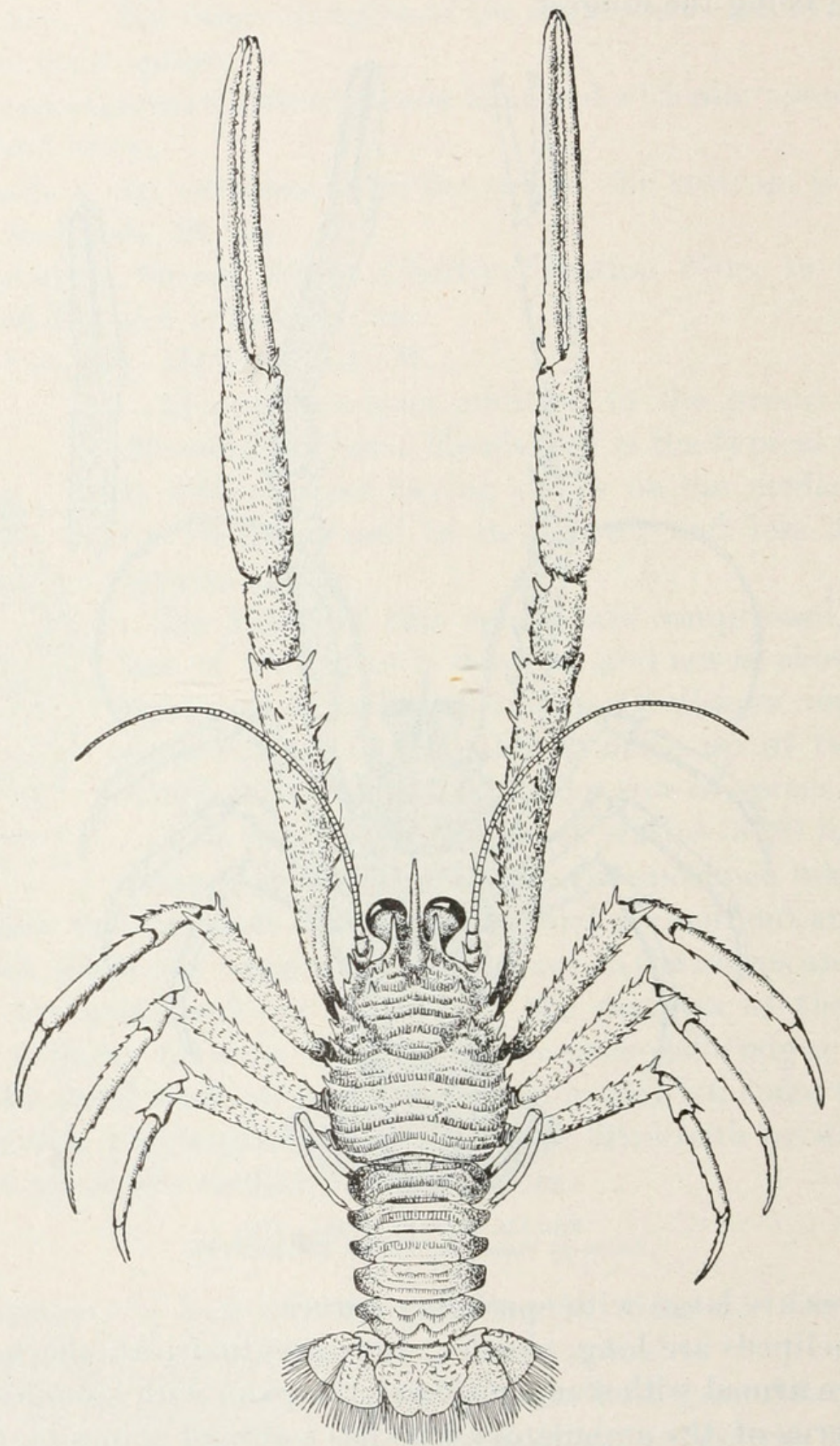

Fig. 13.-MUNida MEXICANA, $\times 3 \frac{1}{3}$.

The carapace is widest at about the beginning of the posterior third; from the widest point it tapers forward to a rather narrow front. The ciliated lines are unusually distant; the cilia are short. 
There are eight spines on the gastric area, six in a transverse line and two separated by the length of the first ciliated line. There is a paired spine in the fork of the cervical suture; no spines occur posterior to these.

The rostrum is nearly twice the length of the eyes, its upper margin is slightly roughened; the supraocular spines are about one-half the length of the eyes and twice the size of the antero-lateral spines. The merus of the maxillipeds is armed on the inferior border with three slender spines and by three small denticles and a spine on the opposite border. The merus of the anterior feet shows upward of twenty-five spines when viewed from above; the carpus is short and is armed with spines and spinules; the palm is short and spinulose; the fingers are much longer than the palm, and in some specimens have a large hiatus near the base. The abdomen is unarmed.

The length of the largest specimen is $12 \mathrm{~mm}$. from the front to the end of the telson; length of the chelipeds, $29 \mathrm{~mm}$.; length of dactyl,

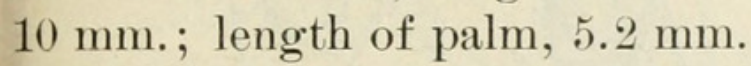

Locality.-West coast of Mexico, 9 to $78 \frac{1}{2}$ fathoms; stations 2794, $2809,2816,2826,2829,2833,2988$, and 3012.

Type-Cat. 20536, U.S.N.M., Albatross station 2816, off Galapagos Islands.

Variations: The proportionate length of the fingers varies.

\section{MUNIDA NUDA, new species.}

The carapace is broadest anteriorly. The transverse lines are widely separated and are almost devoid of cilia; the only unbroken line runs across the middle of the gastric region; it is conspicuous on account of its straightness and its ending at a spine on the sides of the gastric region. There are eight subequal spines on the gastric region - four in a row near the front and a pair on each side near the hepatic region; the larger one of the pair is higher up on the area and at the end of the straight carinated line. The front is broad and produced in the middle. The supraocular spines are short and stout, not reaching more than one-half the length of the eyes.

The rostrum is compressed, serrate above, less so on the sides, and smooth below. The merus of the lower border of the maxillipeds is armed with one large spine. The chelipeds are strikingly different from those of any species examined. They are short; the merus has about ten spines; the largest are on the distal margin; the carpus has two or three large ones on the inner margin and a large number of smaller ones on the upper surface; the outlines of the hand are elliptical; spines run along the borders nearly to the ends of the fingers; there are upward of fifty spines on the outer surface; the inner surface is free from spines. The second segment of the abdomen has 
four spines. Length of body, $12 \mathrm{~mm}$.; length of cheliped, $17 \mathrm{~mm}$; of palm, $4 \mathrm{~mm}$; of fingers, $4 \mathrm{~mm}$.

Locality.- Albatross station 2338 , latitude $23^{\circ} 10^{\prime} 40^{\prime \prime} \mathrm{N}$., longitude $82^{\circ} 20^{\prime} 15^{\prime \prime} \mathrm{W}$.; 189 fathoms. One male. Cat. No. 9516, U.S.N.M.

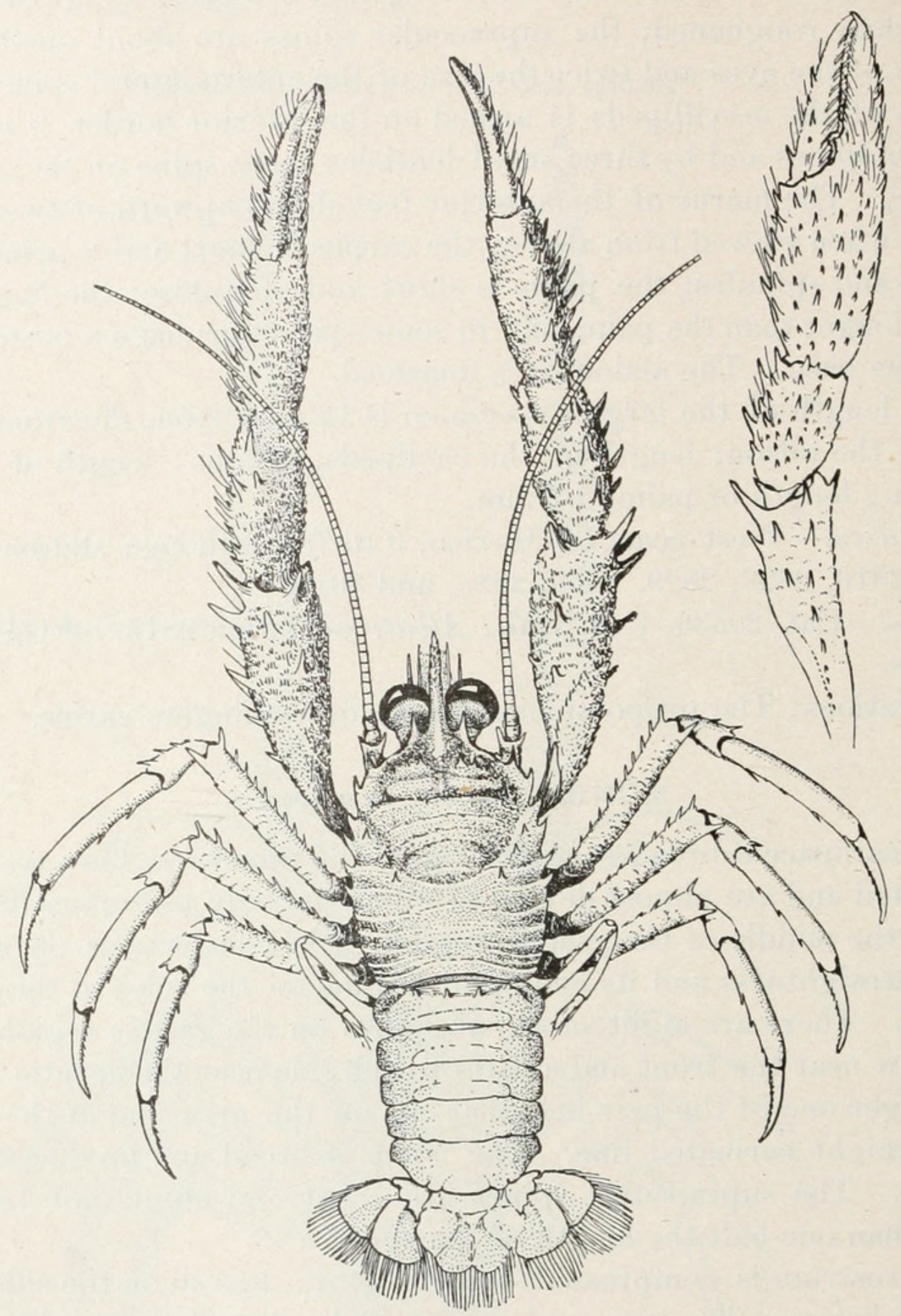

FIG. 14.-MUNIDA NUDA, $\times 4 \frac{1}{3}$.

MUNIDA PERLATA, new species.

The carapace is broadest in the middle, where it nearly equals thi distance from the posterior border to the line of the gastric spines In the single specimen obtained there are but two spines on the cara pace; these are on the gastric area. In line with these, between anc outside, are tubercles which in some specimens would probably occu as spines. The ciliated lines are elevated. There are six small spine on the margin behind the antero-lateral angle. The eyes are small 
the cornea but little dilated and jet black. The merus of the maxillipeds is armed with a single very large spine. Only one of the chelipeds is present; this is short and much flattened. The spines of the merus are small, except those of the distal border, where there are four very large ones. There are two large spines on the inner margin of the carpus and smaller ones elsewhere. The hand is very hairy; there is a row of spines on each margin of the palm. The second segment of the abdomen has a row of spines.

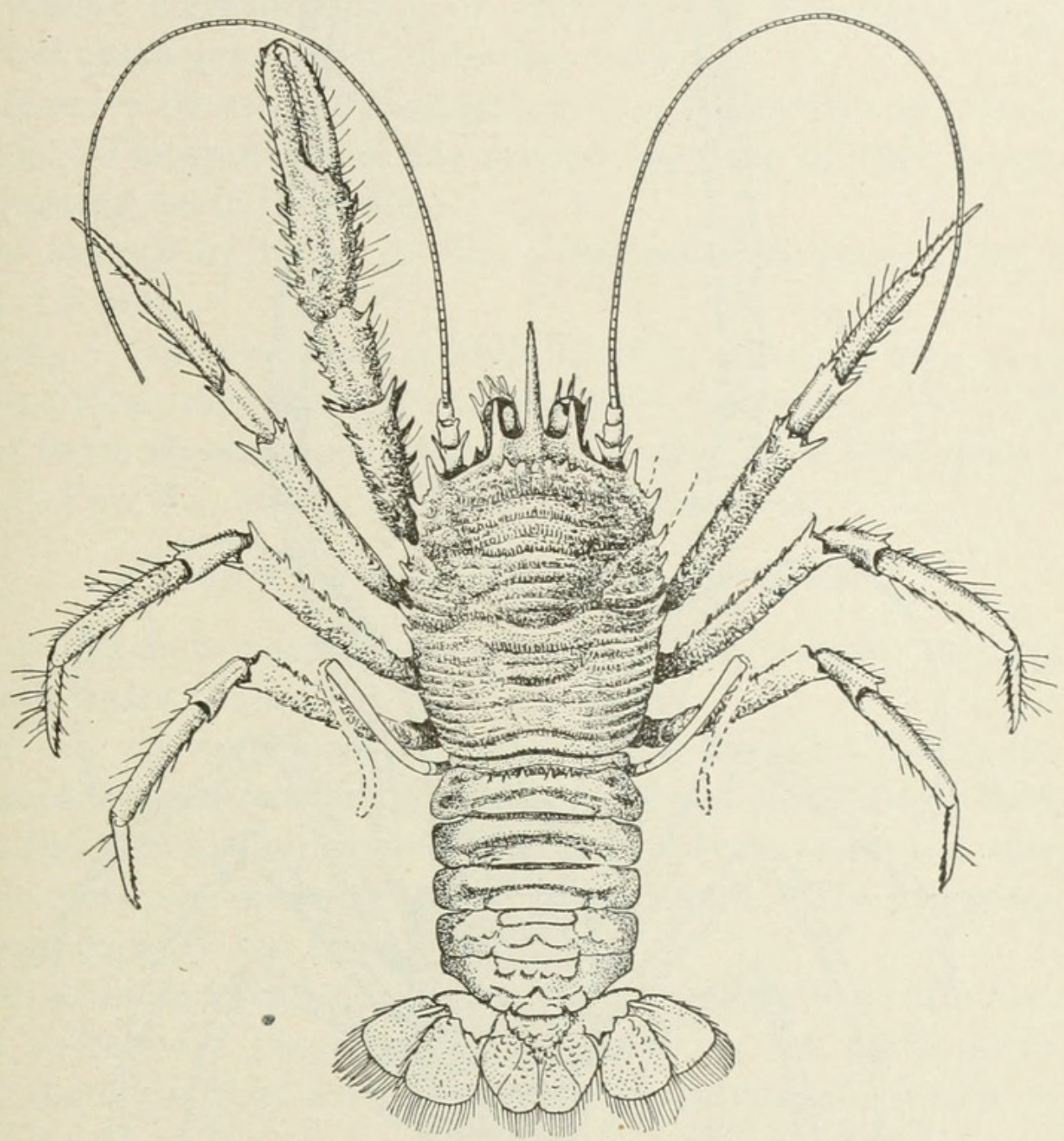

Fig. 15.-MUNidA PERLATA, $\times 2 \frac{1}{5}$.

This species in some of its characters superficially resembles small specimens of $M$. propinqua Faxon and of $M$. microphthalma A. M. Edwards. From the first it is distinguished by its small eyes, from both by the armature of the maxillipeds. The supraocular spines are also much shorter in perlata than in microphthalma.

Length from the front to the end of the telson, $24 \mathrm{~mm}$.; length of the cheliped, $21 \mathrm{~mm}$.; length of palm, $4 \mathrm{~mm}$.; length of fingers, $4 \mathrm{~mm}$.

Loculity.-Station 2808, off the Galapagos Islands; 634 fathoms. One female with eggs.

Type.-Cat. No. 20538, U.S.N.M.

Proc. N. M. vol. xxvi-02-19 
MUNIDA PUSILLA, new species.

The carapace is broadest posteriorly; the sides are arcuate. The transverse lines of cilia are iridescent. The spines and spinules of the gastric area vary in number; the largest are those of the pair behind the supraocular spines; in line with these are one or more pairs of spinules; there is also a pair close to the hepatic area. There are two

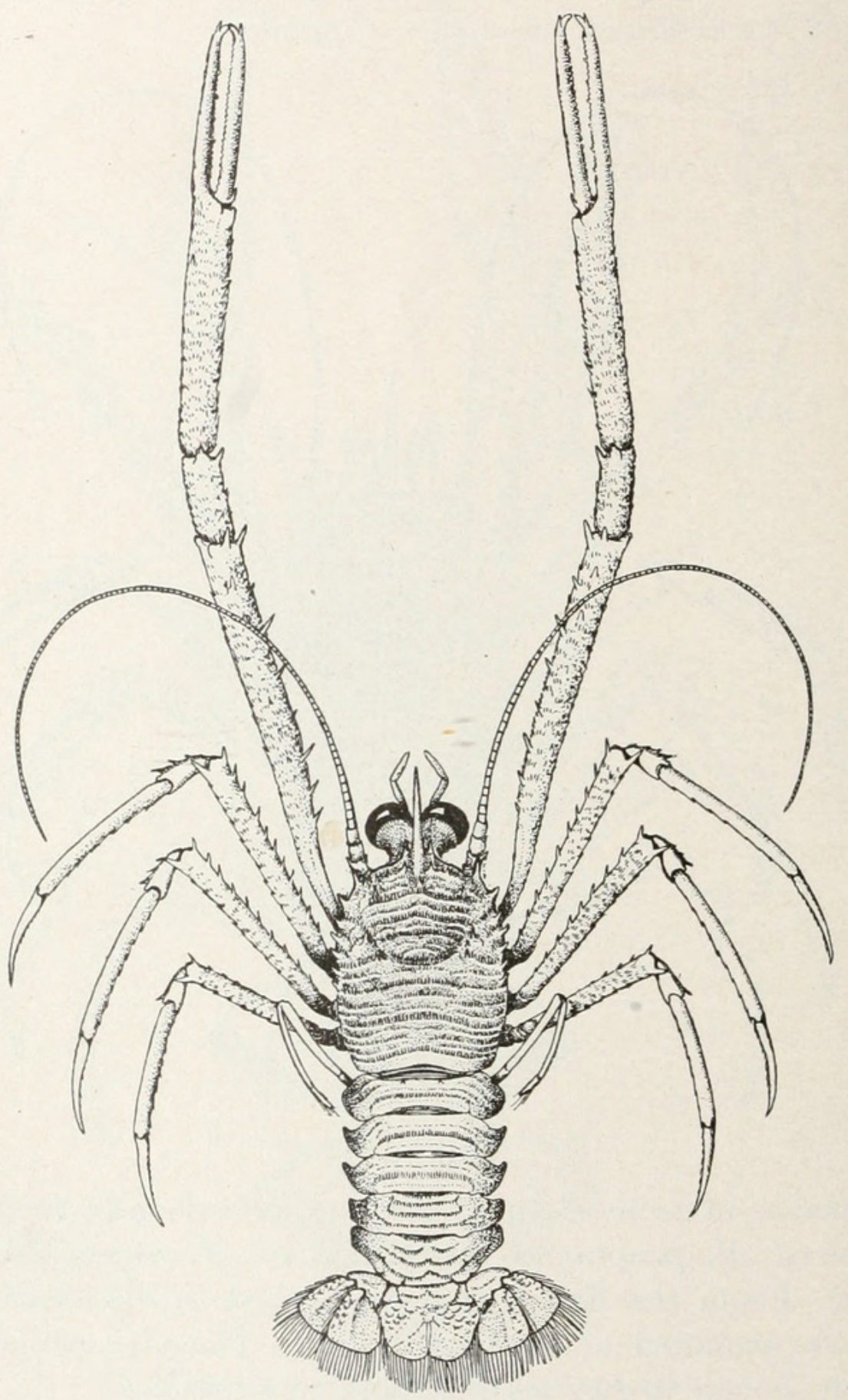

Fig. 16.-MUNidA PUSILla, $\times 4$.

or three spinules in the fork of the cervical suture and one on the branchial region behind the fork of the suture. The sides of the front retreat a little to the antero-lateral angle. The supraocular spines are less than one-haif the length of the eyes. The rostrum is long and slender and is raised but little above the horizontal. The superior mar- 
gin of the maxillipeds is armed with but a single spine. The anterior feet in the male are very long and slender; in many specimens there is a prominent hiatus near the base of the fingers of one hand; in one specimen the hiatus exists in both hands. The spines, or rather spinules, of the merus are very small; the palm is scabrous, much as in $M$. iris. There are but few very small spines on the ambulatory legs; the only ones at all prominent are those at the distal ends of the merus and carpus. The second segment of the abdomen of many specimens has a widely separated pair of spinules; in other specimens with correlated characters the spinules are wanting.

The females are readily distinguished by the shorter and more spiny chelipeds. The spinules of the second segment of the abdomen are often wanting, as in the males.

Male: Length of body, $10 \mathrm{~mm}$; chelipeds, $28 \mathrm{~mm}$; palm, $8 \mathrm{~mm}$.; fingers, $4.5 \mathrm{~mm}$.

Locality. - Albatross station 2405, Gulf of Mexico; also, at stations 2120, Caribbean Sea; 2365, 2372, 2406, 2407, and 2640, Gulf of Mexico.

A lot of three specimens is labeled "Warsaw, New Providence."

Type.-Cat. No. 20539, U.S.N.M. Station 2405.

MUNIDA QUADRISPINA, new species.

The carapace is narrowest near the front margin; the posterior angles are much rounded.

There are six spines on the gastric area, four in a line in the usual place behind the supraocular spines, and one on the sides near the hepatic region; the terminal spines of the line are very weak and small, but one spine occupies the anterior branchial region. The marginal spines vary from eight to ten in number.

The rostrum is long and compressed, moderately serrate above and slightly so below. The supraocular spines do not reach quite to the ends of the eyes; they are united to the rostrum for nearly one-half of their length. The eyes are small. The merus of the maxillipeds is armed on the inferior border with four spines; the first and last are long, the others short. The distal ends of the terminal segments of the maxillipeds are rather more dilated than is usual in the genus.

The anterior feet are well set with spines and spinules. The merus has fourteen spines; the carpus about twenty spines and spinules; and the palm upwards of thirty.

The ambulatory feet are compressed; the meral and carpal joints are spiny--spines short, blunt, inconspicuous.

Length of a large specimen, $35 \mathrm{~mm}$.; length of palm, $15 \mathrm{~mm}$; length of fingers, $13 \mathrm{~mm}$.

Locality.-Albatross station 2960; 267 fathoms, 2878.

Type.-Cat. No. 20537, U.S.N.M.

Also taken at stations 2861, 2866, 2871, 2878, 2886, 2936, 3053, 3104, $3170,3183,3445,3449,3454,3457,3461,3666$, and 3673 . One speci- 
men in the collection is labeled Sitka, Alaska, Dr. W. H. Jones, U. S. N., 1882, No. 13947.

The merus of the maxillipeds is commonly armed with four spines on the lower border; variations are numerous; while the two medium spines are usually smaller than the others. This is not always the case, as they may range from small tubercles to large spines.

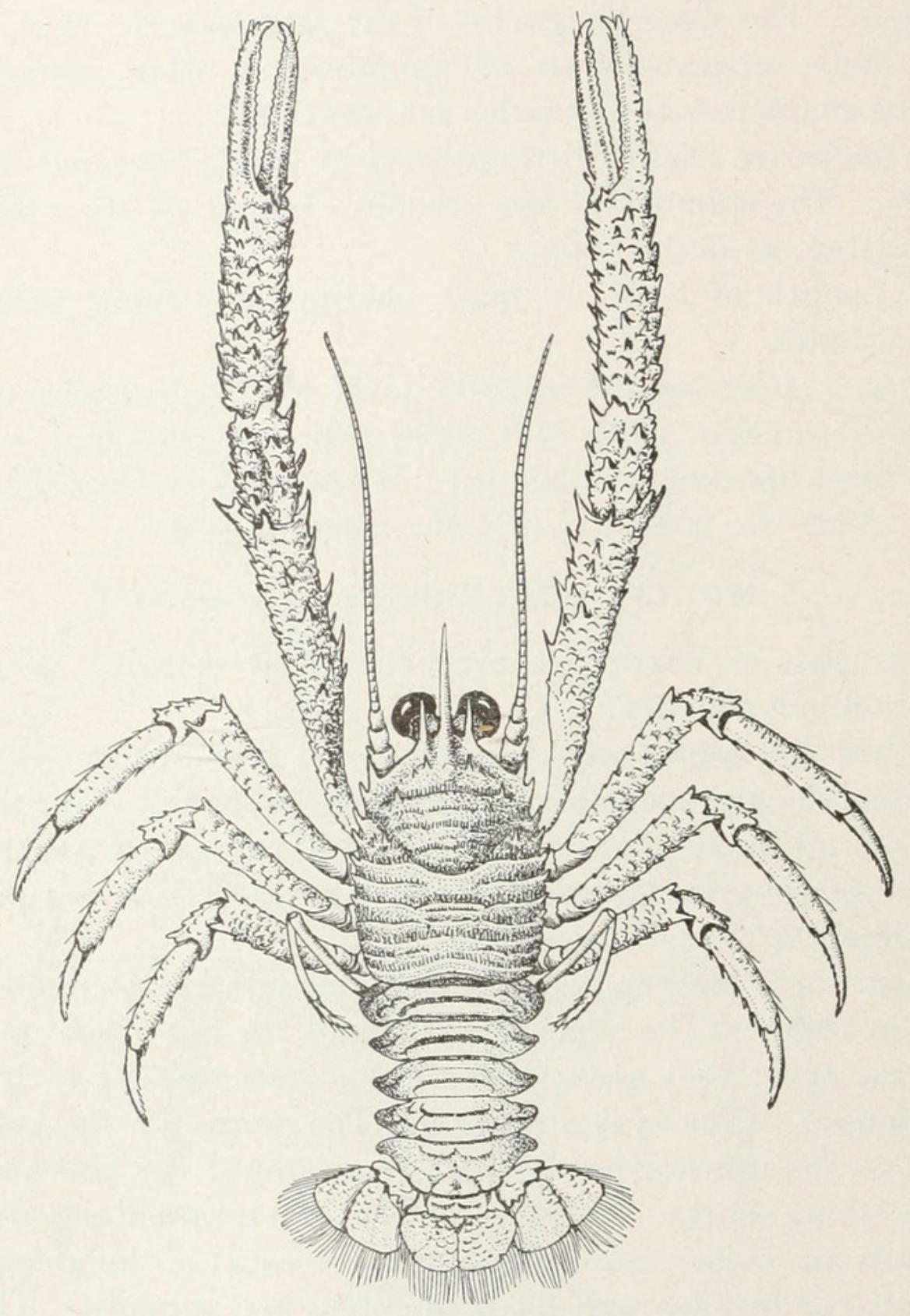

Fig. 17.-MUNIDA QUADRISPINA, $\times 1 \frac{1}{2}$.

MUNIDA SCULPTA, new species.

The carapace is broadest behind the middle, and is moaerately swollen. The ciliated lines are rather more than usually elevated, and its anterior edges are thickly set with minute denticles. The cilia are worn from the anterior and central portions of the surface, but on the region near the fifth pair of legs are intact, and are brightly iridescent; the cilia cover about two-thirds of the space between the lines. The carapace is armed with more spines than is usual in species with 
unarmed abdomens. A row of eight spines on the gastric area is arranged in size as follows: The gastric pair is the largest; the next are the second and fourth pairs; those of the third pair are little more than spinules; a little behind the third and fourth paired spines of the front row is a spinule, and on the sides are two other paired spines. On each of three females there is a denticle near the extremities of a ciliated line forming the anterior margin of the posterior lobe of the

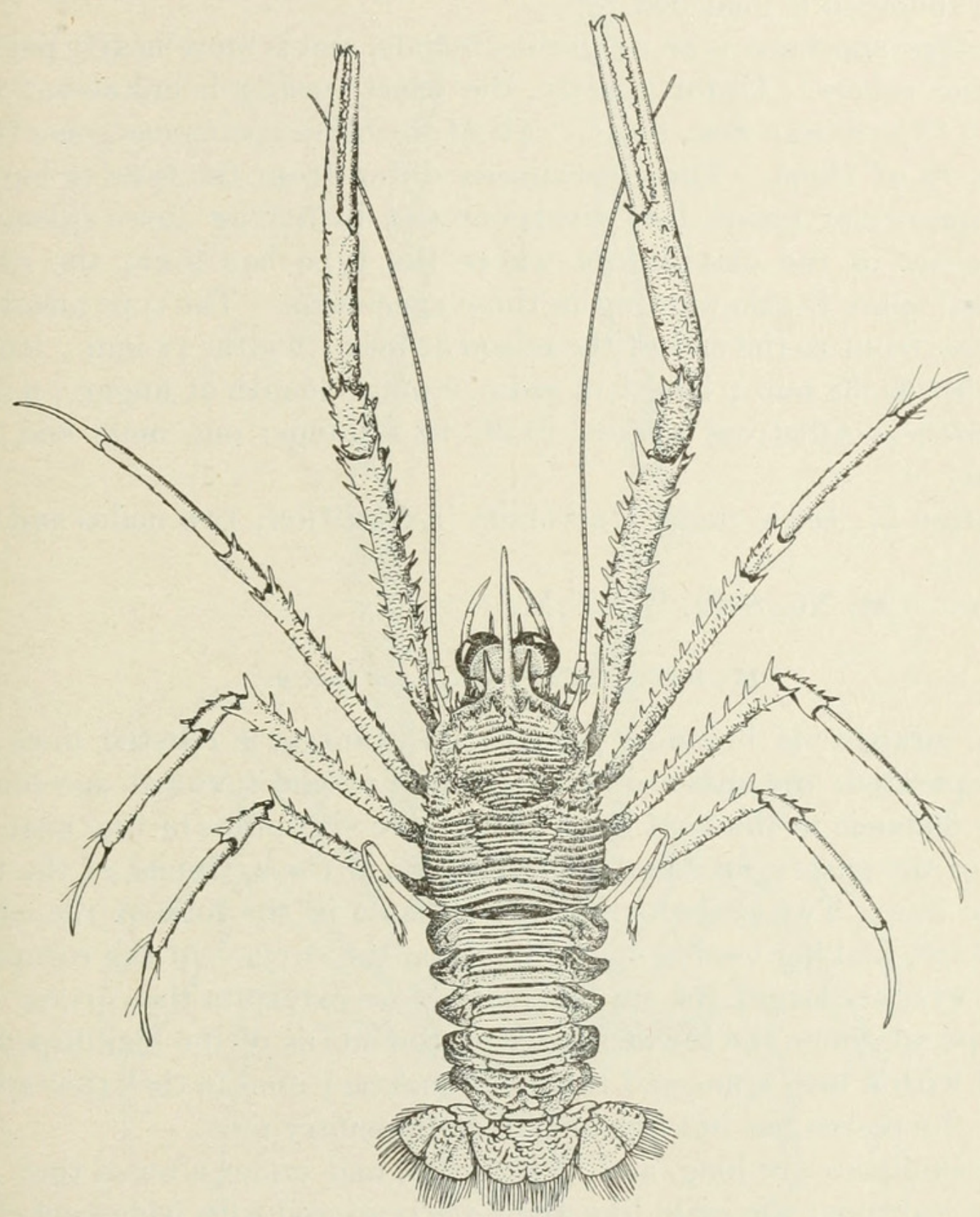

Fig. 18,-MUNIDA SCULPTA, $\times 2$

gastric area. These spinules are wanting in the three males. In the fork of the cervical suture are three or four spines; on the border behind the suture there is a row of from three to five paired spinules. The rostrum extends beyond the eyes by more than one-half of its length, it is slender, slightly compressed, and is obscurely serrated above.

The supraocular spines extend to about the middle of the eye. The antero-lateral spines equal the supraoculars in length. 
The inferior border of the merus of the maxillipeds is armed with three or more spines on the proximal and one on the distal end.

The chelipeds are shorter than those of $M$. irrasa. The merus has three rows of ten or more spines in good alignment; the surfaces on each side of the middle row are flat and diverge at an angle of 90 degrees. There are seven or eight spines on the carpus and two rows on the inside of the palm; all of the articles are scabrous throughout.

The abdomen is unarmed.

The type specimen is an ovigerous female, and is more nearly perfect than the others. Unfortunately, the exact locality is unknown; it is labeled "Caribbean Sea, 1884." All of the other specimens come from the north of Cuba. These specimens differ from the type in having the supraocular spines less divergent and in having three spines on the merus of the maxillipeds where the type has four; the distal terminal spine is also wanting in these specimens. The type measures from the front to the end of the telson $32 \mathrm{~mm}$.; width, $12 \mathrm{~mm}$.; length of chelipeds, $38 \mathrm{~mm}$; length of palm, $9 \mathrm{~mm}$.; length of fingers, $9 \mathrm{~mm}$.

Locality.-Albatross station 2159; 98 fathoms; one male and one female.

(Station 27, Iowa State University Expedition; two males and one female.)

Type.-Cat. No. 8942 , U.S.N.M.

MUNIDA SIMPLEX, new species.

The carapace is broadest behind; the transverse ciliated lines are well separated; the cilia are iridescent and extend forward one-fourth of the distance to the next line. There are six spines in line near the front of the gastric area and a single spine at the extremes of the first ciliated line. Two paired spines are situated in the fork of the cervical suture, making twelve spines in all on the surface of the carapace.

The eyes are large; the supraocular spines extend to the cornea. In the type specimen the lower border of the merus of the maxillipeds is armed with a long spine and three rudimentary ones in the other specimens; the merus has but one or two rudimentary ones.

The chelipeds are long and cylindrical, and under a lense they are lightly scabrous; the scale-like areas are bordered with iridescent cilia.

The merus has about twenty-five spines, large and small, in a dorsal view. The spines of the carpus are small; there is a row of small spines near the crest of the palm. The hands are long and a little curved inward, and bent slightly downward from the base of the fingers, which are a little longer than the palm. In the specimen selected for the type the chelipeds are unequal; the left one is the smaller, and has the most marked bend at the base of the fingers, making a large shallow sinus in the lower outline; the outline of the dacty! is concave; the curves in the right hand are not so strong as in the left, and 
better represent the hands of the three specimens from the other stations.

The length of the body from the front to the end of the telson is $14 \mathrm{~mm}$. The chelipeds are 34 and $37 \mathrm{~mm}$. in length, respectively, and the palm of the right is $9 \mathrm{~mm}$.; the fingers, $9.2 \mathrm{~mm}$.

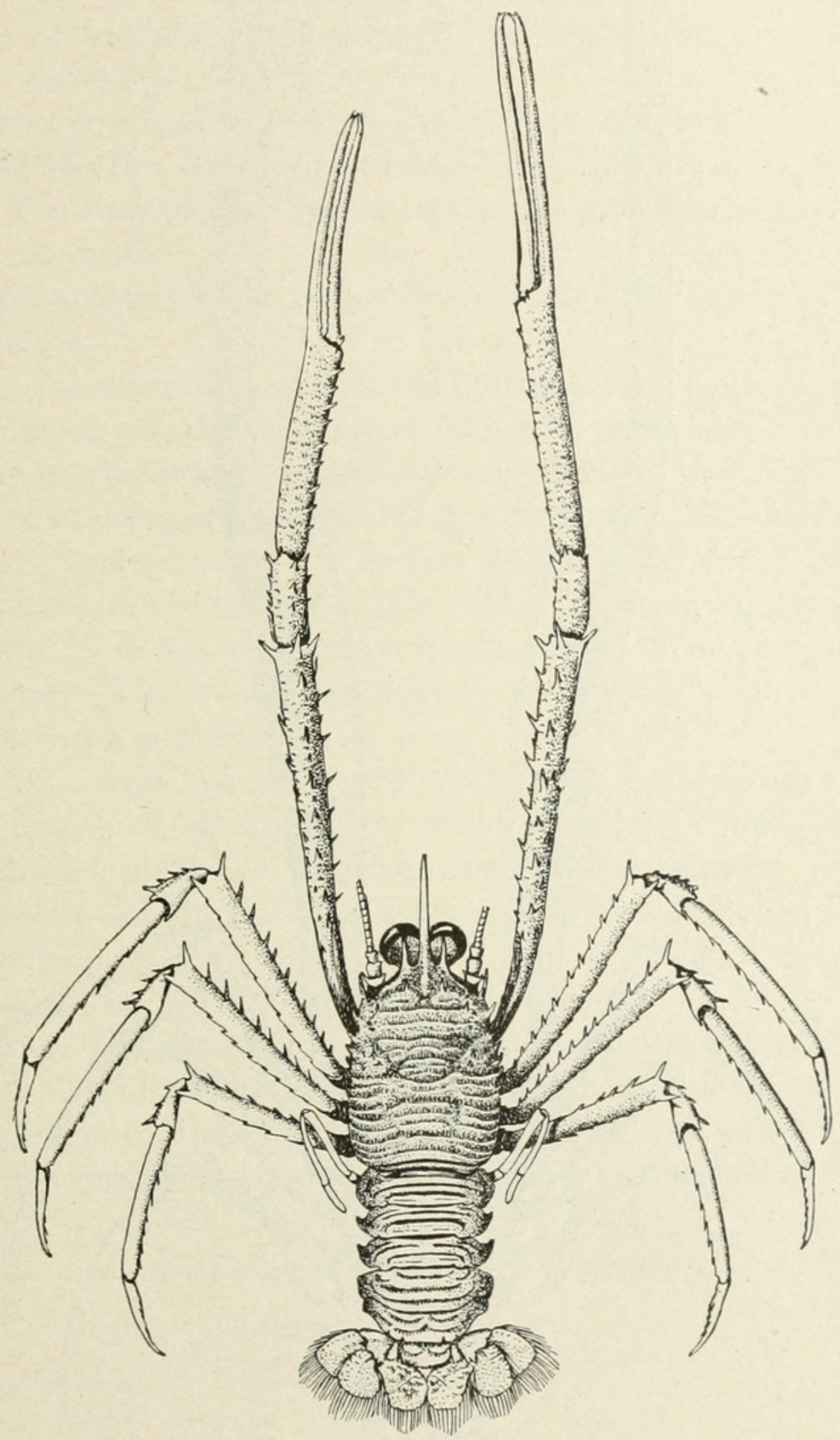

Fig. 19.-MUNidA SIMPLEX, $\times 3$.

Type.-Cat. No. 7789, U.S.N.M., from Albatross station 2169; depth 78 fathoms.

A second specimen was taken at station 2320 in 130 fathoms; two other srecimens were taken at station 2322 in 115 fathoms: the three stations were off Habana, Cuba. 
MUNIDA TENELLA, new species.

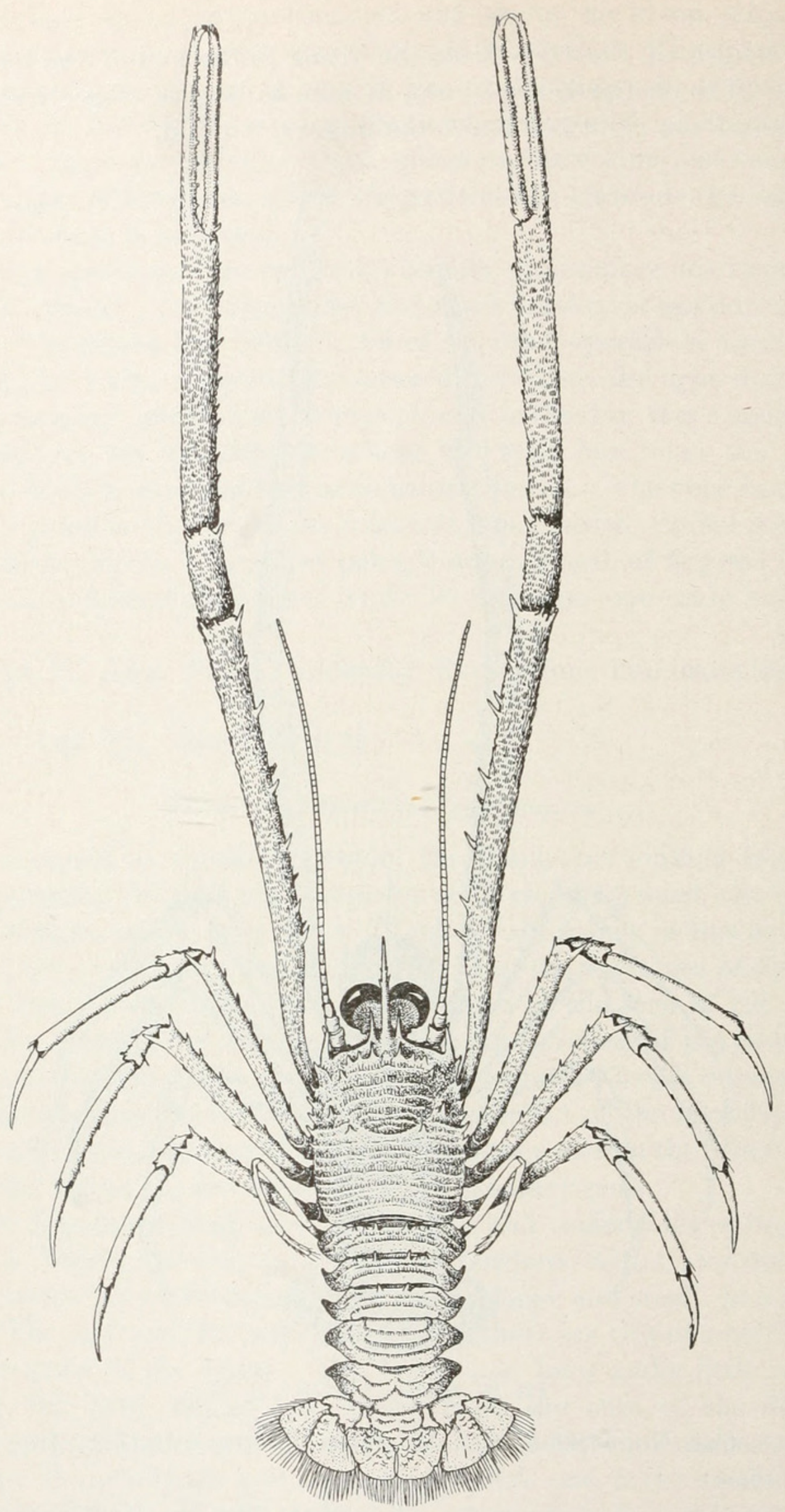

Fig. 20.-MUNidA TENELLA, $\times 3$.

The carapace is broadest in the anterior-middle, tapering slightly forward to the slender spines behind the antenna. The ciliated lines 
are well separated, the cilia are short and slightly iridescent; the lines are for the most part unbroken. The gastric pair of spines is small, and the other spines of the gastric row are very small; in some specimens they should be designated as spinules. There are eight spines in the gastric row and two at the extremities of the first ciliated line, making ten spines on the gastric area. A large spine occupies the area in the fork of the cervical suture and a second paired spine the border just behind the fork.

The rostrum is about twice as long as the eyes; two or more spinules break the continuity of the sides; the upper border is subserrate. The supraocular spines are small and reach only about the middle of the eyes.

The eyes are large, the cornea is much inflated, and the peduncles are very short.

The inferior margin of the merus of the maxillipeds is armed with a large spine on the proximal part and by a short spine on the distal part. The merus of the chelipeds is armed with three rows of spines, the inner row with seven, the middle with six, and the outer with nine.

There are five spines on the carpus, three on the distal border, and two small ones on the inner margin. The upper margin of the palm has a row of from ten to fourteen small spines. The ambulatory feet are spinulose. The second segment of the abdomen has a line of six spines, the third and fourth two each.

Length of a large specimen, from the front to the end of the telson, $18 \mathrm{~mm}$; length of chelipeds, $39 \mathrm{~mm}$; of palm, $9 \mathrm{~mm}$.; of fingers, $8 \mathrm{~mm}$. Taken by the U. S. Fish Commission steamer Albatross at several stations off St. Josephs Island, Gulf of California, in from 39 to 71 fathoms.

Type.-Cat. No. 20540, U.S.N.M.

Variations: The gastric row of spines may have six spines in small specimens. The rostrum may show several spinules or none. The second segment of the abdomen may have but one pair of spines in some of the smaller specimens; usually six can be made out under a lens.

\section{Genus MUNIDOPSIS Whiteaves.}

KEY TO THE SPECIES OF MUNIDOPSIS EXAMINED.

a. Eye spines present.

$b$. Eye spines short, conical.

c. Chelipeds short, bearing but few spines.

d. Carapace broadest behind; gastric area with six spines..... aculeata, p. 315

d. Carapace broadest in front; gastric area with two spines.subsquamosa, p. 327

$c$. Chelipeds elongated, bearing numerous spines.

d. Abdomen unarmed.

e. Auxiliary eye spine at the base of the large eye spine......scabra, p. 325

e. Auxiliary eye spine wanting......................... tanneri, p. 327

d. Abdomen armed ........................................... p. 321

$b$. Eye spines long. 
c. Without spines or teeth on the front behind the antennal peduncle.

d. With four spines on the posterior margin of the carapace ....bairdi, p. 317

d. Without spines on the posterior margin; margin roughened by a large number of sharp granules.

e. Rostrum straight ................................... . . . . . 316

e. Rostrum curved ............................... . beringana, p. 279

c. With spines or teeth on the front behind the antennæ.

d. Spines wanting on the gastric area ................. spinoculata, p. 327

d. Spines on the gastric area two or more.

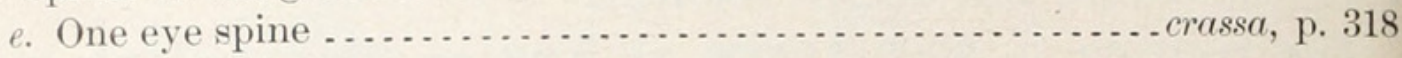

e. Two eye spines.

f. Crest of palms spiny.

g. Merus of chelipeds with ten to twelve spines (exclusive of the terminal spines) . . . . . . . . . . . . . . . . . . . . similis, p. 326

g. Merus of chelipeds with six to eight spines ........... verrilli, p. 291

f. Crest of palms not spiny ........................ nitida, p. 323

a. Eye spines not present.

b. Rostrum broad, with subparallel sides; extends considerably beyond the eyes where it terminates in a trident.

c. Rostrum long and strongly bent upward, as in Galicantha.

d. Carapace without spines except on margin .............. expansa, p. 282

d. Carapace with spines on the surface ..................... gilli, p. 283

c. Rostral point short, horizontal (Galathodes).

d. Gastric area armed with two spines or spinules.

e. Palm spiny above and below ....................... trifida, p. 329

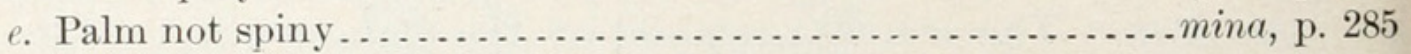

d. Gastric area without spines or spinules.

e. Maxillipeds with the inferior margin of merus armed with three spines.

$f$. Sides of rostrum convex ....................... . tridentata, p. 328

$f$. Sides of rostrum straight . . . . . . . . . . . . . . . . bahamensis, p. 278

e. Maxillipeds with the inferior margin of the merus armed with two spines.

$f$. Both spines slender from the base.

g. Carpus of chelipeds with a single long slender spine.tenuirostris, p. 289

g. Carpus with three long slender spines............. latifrons, p. 321

f. Both spines not slender.

g. Fingers of the chelipeds acuminate from base to tip_acuminata, p. 277

g. Fingers not acuminate.......................... modesta, p. 286

$b$. Rostrum not tridentate.

c. Abdomen unarmed.

d. Eyes movable.

e. Gastric area with two very short conical spines ....... . platirostris, p. 324

e. Gastric area without spines.

$f$. With a sharp spine at the anterolateral angle.

g. Rostrum broadest at base.

h. Spine of anterolateral angle very short.......... cylindropus, p. 281

$h$. Spine of anterolateral angle long ................. sigsbei, p. 326

g. Rostrum broadest in the middle ................... armata, p. 316

$f$. Without spine on the anterolateral angle.

g. Eyes long, cylindrical ...............cylindrophthalmus, pp. 319, 281

g. Eyes short ......................................... polita, p. 324

d. Eyes immovable.

e. Surface of carapace smooth, punctate ..................espinis, p. 282

e. Surface of carapace rough, coarsely granulated.......... . squamosa, p. 327

c. Abdomen armed with spines or tubercles. 
d. Rostrum armed with lateral spines.

e. Rostrum armed with a single pair of lateral spines.

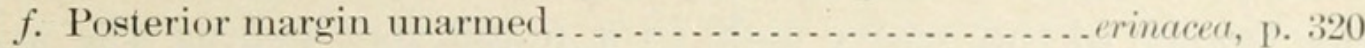

f. Posterior margin armed with spines.

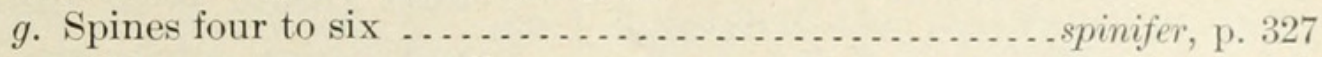

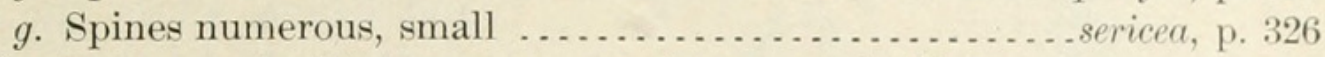

e. Rostrum armed with two or more spines on each side.

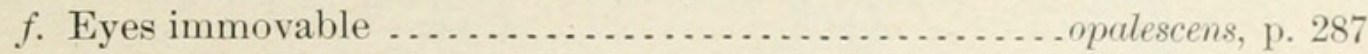

f. Eyes movable ... . . . . . . . . . . . . . . . . . . hamata, p. 320

d. Rostrum not armed with lateral spines.

e. Armature of the abdomen not confined to the median line.

$f$. Armature of abdomen consisting of small conical spines, uniform in size, placed in a double row on the second, third, and fourth

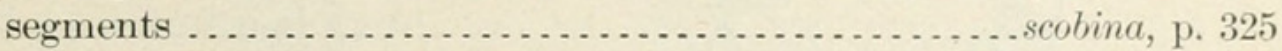

Armature consisting of prominent spines on the median line and a single spine on each side.

g. Spines on the posterior margin of carapace, 2 . . . serratifrons, p. 326

g. Spines on the posterior margin of carapace, more than 2 .hastifer, p. 284

e. Armature of abdomen confined to the median line.

$f$. Gastric area armed with 1 or more spines or tubercles.

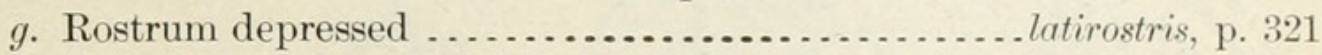

g. Rostrum curved upward.

h. Median line on the gastric area free from spines . . . villosa, p. 330

$h$. Median line on the gastric area armed with spines or tubercles.

$i$. Orbicular sinus well developed.

$k$. Rostrum strongly curved upward and much longer than the

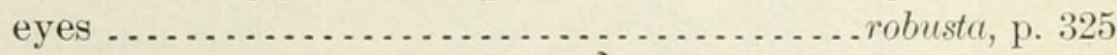

$k$. Rostrum nearly horizontal and but little longer than the eyes. townsendi, p. 290

$i$. Orbicular sinus lacking.

$k$. Carapace of nearly uniform width, widest in middle, not cut

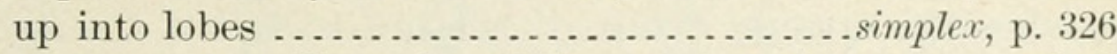

$k$. Carapace not uniform in width, cut into lobes by cervical sutures.

l. Broadest near anterior end ............... longirostris, p. 322

l. Broadest near posterior end ................... curvirostra, p. 319

f. Gastric area lacking spines or tubercles. $a$

g. With sharp anterolateral spines.......................

g. Anterolateral spines wanting.

h. Rostrum short, broad, concave, apex rounded.

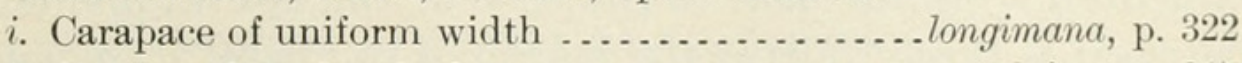

i. Carapace broadest in front .............................. 317

h. Rostrum acuminate.

i. Lateral margins of carapace straight ........... quadrata, p. 325

i. Lateral margins arcuate ............................... p. 316

MUNIDOPSIS ACUMINATA, new species.

The rostrum extends beyond the eyes about one-third of its length; the base is broad; the rostral point is twice as long as the lateral points. The antennal spines are a little smaller than the rostral spines. The spines of the lateral margin are four in number, including the

a $M$. aspera may be an exception, as the rough granules are general on the carapace. 
anterolateral spine. The posterior spine is situated just behind the branch of the cervical suture, as indicated by a slight notch; the anterior branch of the suture ends in a notch just behind the anterolat-

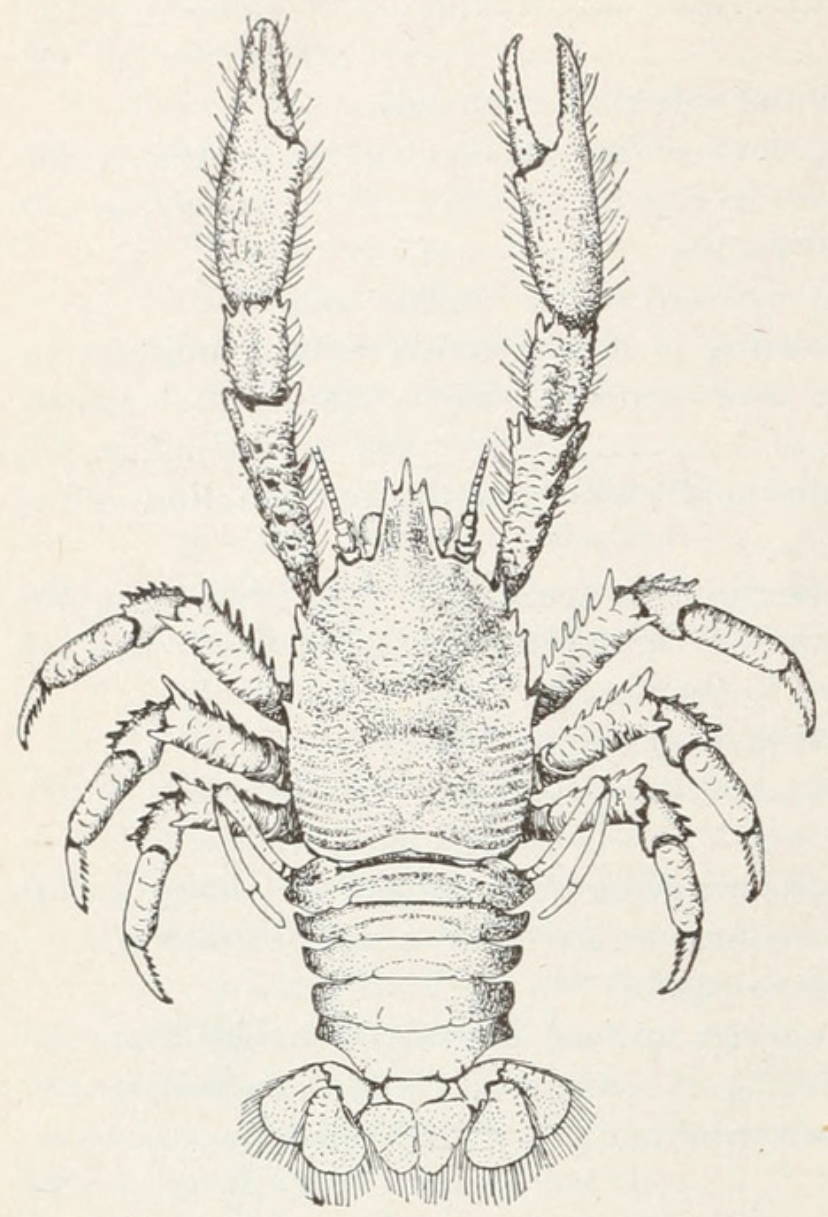

Fig. 21.-Munidopsis ACUMinata, eral spine; both branches are indistinct, while the groove is well marked behind the gastric area.

The carapace is roughened by short, granulose rugæ; there are no spines on any part of the gastric area. The spines of the ambulatory legs are confined to the crests of merus and carpus. The chelipeds have spines on the crest and on the inner margin of the merus and on the distal margin of the carpus.

The lower margin of the hand is nearly straight, with a slight swelling at the palm and a slight sinus at the base of the fingers; the fingers are acuminate, the outline of the closed fingers from the base to the tip is triangular. This feature distinguishes the species from all related forms of the subgenus Galathodes.

The two specimens, one male and one female, were taken by the Albatross at station 2663, in 421 fathoms, off South Carolina.

Type.-Cat. No. 11490, U.S.N.M.

\section{MUNIDOPSIS BAHAMENSIS, new species.}

The rostrum is seven-eighths as long as it is broad at the base, measured from the base to the base of the lateral points; between the points it is three-fourths the length of the base. The lateral teeth are large and stand out well from the margin. The inferior margin of the merus of the maxillipeds is armed with three spines; the proximal spine is broad at the base; the second is as long and is uniform in size; the third is short, sometimes inconspicuous or wanting. The merus of the chelipeds has two rows of spines and two large spines between them; the carpus has a large spine at the inner angle and a smaller one at the condyle; the palm is broad and unarmed; in large specimens there is a hiatus between the fingers. The upper margins of the meral joints of the ambulatory feet bear a row of spines; the 
carpal joints have a single spine placed at the distal angle of the upper margin.

Length of a large male from the front to the end of the telson, 44 $\mathrm{mm}$.; length of chelipeds, $51 \mathrm{~mm}$.; length of the carapace, $18 \mathrm{~mm}$.; width, $16 \mathrm{~mm}$.

Locality.-Albatross station 2669, 352 fathoms, off the coast of Florida.

Type--Cat. No. 20555, U.S.N.M.

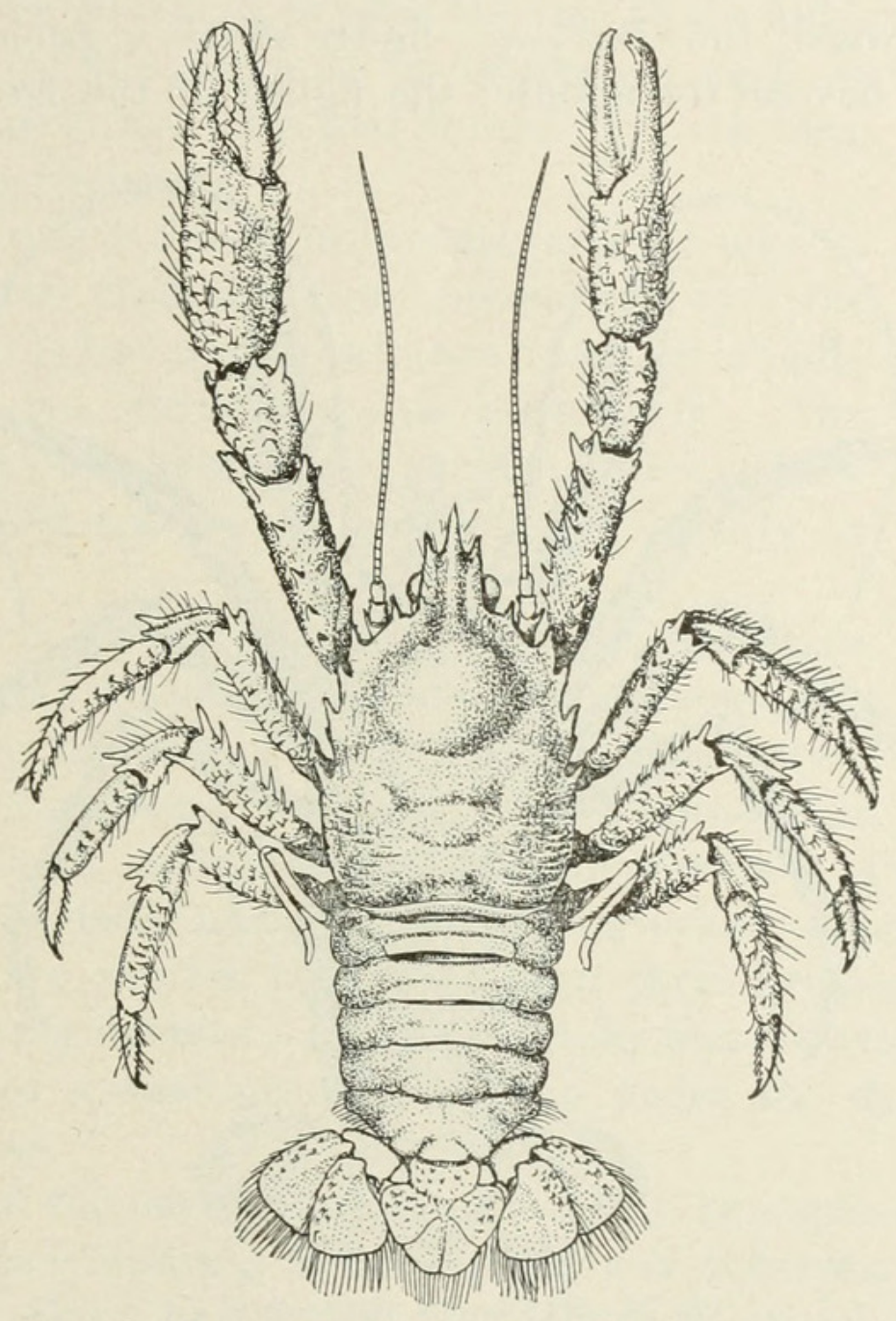

Fig. 22.-MUNidopsis BAHAMENSIS, $\times 1 \frac{1}{4}$.

\section{MUNIDOPSIS BERINGANA, $₫$ new species.}

Three specimens of a Munidopsis were dredged in Bering Sea, which at first sight would be called $M$. antonii; but a careful examination shows that the texture of the carapace differs, that the rostrum is curved and not as in M. antonii, which, though directed upward, is perfectly straight.

The carapace of the Bering Sea species is, in its texture, more like

a Allowance must be made for the figure of this species, as the specimens were soft; the exuviæ still partly attached to one. The small one is, however, hard, and this confirms the specific characters given to the large specimens. The short rugose lines of the posterior sides are more marked in the specimens than in the figure. 
that of the $M$. antonii figured by Henderson in the Challenger Anomura. The sharp granules are arranged in short lines or squamæ on the posterior portion of the carapace. The specimen figured has about twenty short, sharp spines on the gastric area. The smallest specimen, a male, has fifteen; a large female, with a part of the exuviæ yet attached, has the same spination as a specimen of $M$. antonii from the Paris Museum of Natural History (taken by the Talisman), but otherwise it is like its companions. The Talisman specimen and the Bering Sea species agree in being broadest behind and tapering gradually forward; the Challenger figure shows a species slightly narrower a little beyond the middle; the figure of the latter also shows

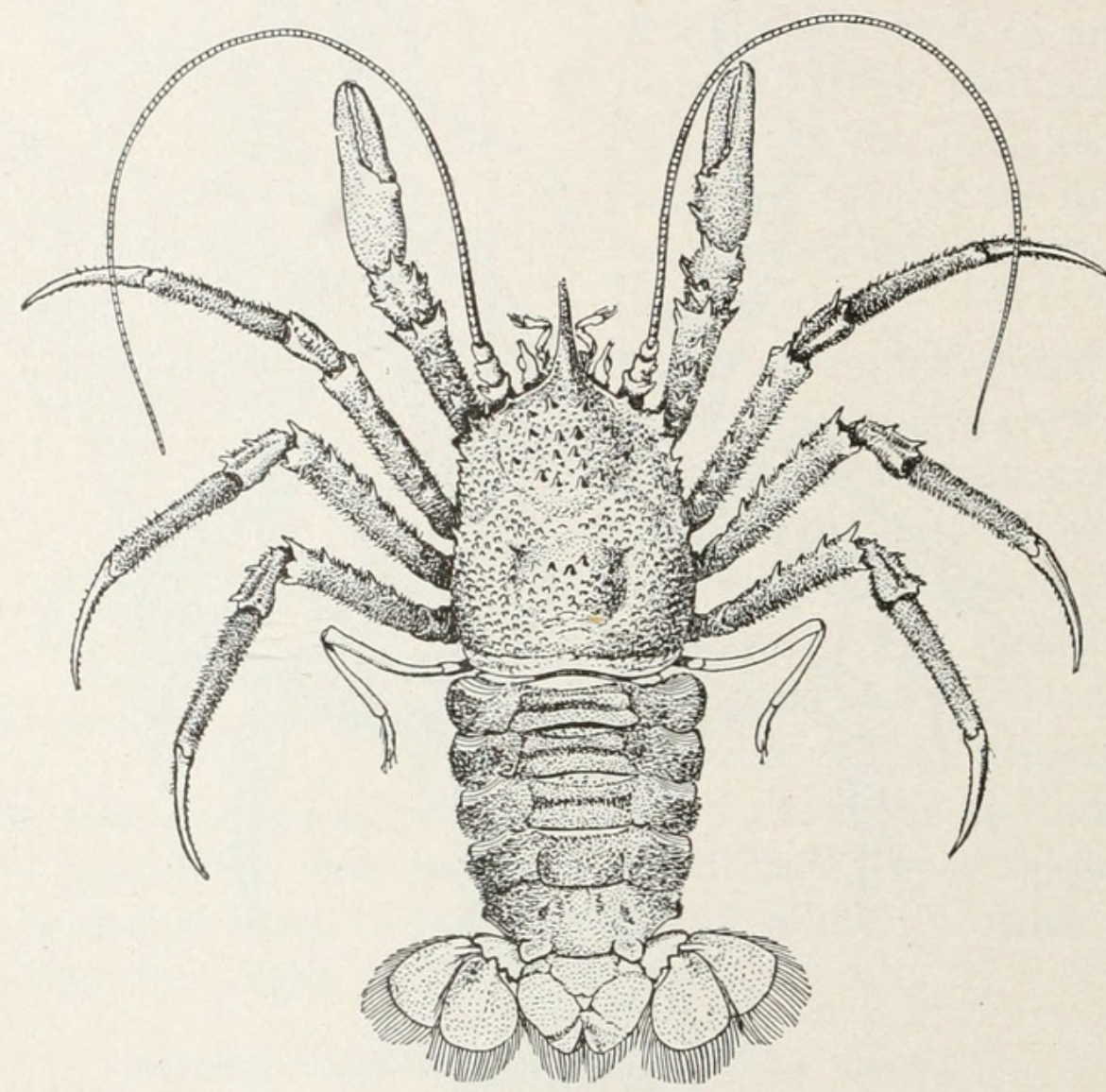

Fig. 23.-MUNIDOPSIS BERINGANA, $\times \frac{2}{3}$

a slight difference in the spines of the gastric area - a single spine in the center where the other species have two. In comparing $M$. berin gana with $M$. aculeata Faxon, the spination of the gastric area is very similar. The cornea of aculeata is much larger than beringana and the eye-spines smaller; the rugæ of the posterior portion of the carapace are coarse and separated in aculeata, and exceedingly numerous and crowded in beringana

Length of the large female, figured from the middle of the posterior margin to the margin behind the eye, $32 \mathrm{~mm}$.; greatest width, $28 \mathrm{~mm}$.

Locality.-From Albatross station 3603, 1.771 fathoms.

Type.-Cat. No. 20557, U.S.N.M. 
MUNIDOPSIS CYLINDROPUS, new species.

The rostrum is sharp; the distal one-half is triangular in cross section; it extends horizontally forward beyond the eyes by about onehalf of its length. From the apex to the eyes the upper margin is a sharp ridge; from this point the ridge is forked, the branches running back to the front of the gastric areolation, inclosing a slight triangular depression. The antero-lateral angles are right angles with sharp apices; that portion of the front which lies between the bases of the antennæ is much advanced beyond the line of the angles.

The articles of the antennal peduncles are each about as long as broad; the flagelli are long and thread-like, reaching far beyond the chelipeds.

The carapace is $5.5 \mathrm{~mm}$. in breadth and $6.5 \mathrm{~mm}$. in length, measured from the front behind the eye; the lateral margin is but slightly arcuate from the middle to the front, but much more so posteriorly. The areolations are protuberant; the surface is everywhere broken by raised transverse lines varying greatly in length.

The chelipeds measure $20 \mathrm{~mm}$. in length and are almost uniformly $1 \mathrm{~mm}$. in diameter throughout, the palm enlarging to $1.2 \mathrm{~mm}$. at the base of the dactyl.

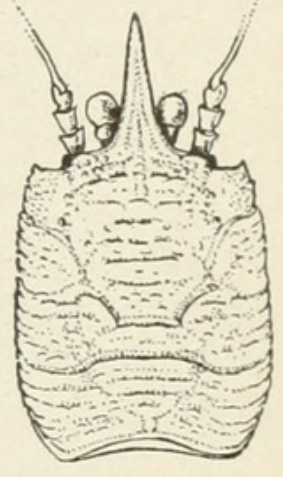

FIG. 24.-MUNIDOPSIS CYLINDROPUS, The merus and carpus are granulated, while the palm is smooth and slightly iridescent; two spines arm the inner surface of the merus and two or three the distal margins of both merus and carpus.

The fingers are shorter than the palm; their prehensile edges are thin and minutely dentate. The ambulatory feet are granulated; with the exception of a small graduated comb under the dactyls they are free from spines.

The merus of the maxillipeds is armed with two spines.

The abdomen is wanting in both spines and tubercles; the margins of the second, third, and fourth segments are raised, forming deep transverse channels.

This species in its general appearance very much resembles Munidopsis cylindrophthalmus, but close inspection shows marked differences in many characters. The latter species has a much broader rostrum and smaller eyes; the carapace is much smoother, and its antero-lateral angles are rounded.

This single specimen, a female without eggs, was taken by the Albatross at station 3697, in 265-120 fathoms, off Honshu Island, Japan. Type.-Cat. No. 26163, U.S.N.M. 
MUNIDOPSIS ESPINIS, new species.

The rostrum is about three times as long as broad in the middle; the apex is blunt. The carapace is about as broad as long, subquadrate; the antero-lateral angle is formed by a broad, triangular, blunt tooth, which projects beyond the base of the rostrum. The margin between the rostrum and the tooth is divided by a triangular projection into two parts; the inner part is semicircular. In this the eye is immovably fixed both to the front and rostrum. On the margin behind the antero-lateral tooth is a double-pointed tooth; behind this and in front of a deep transverse depression is a small tooth.

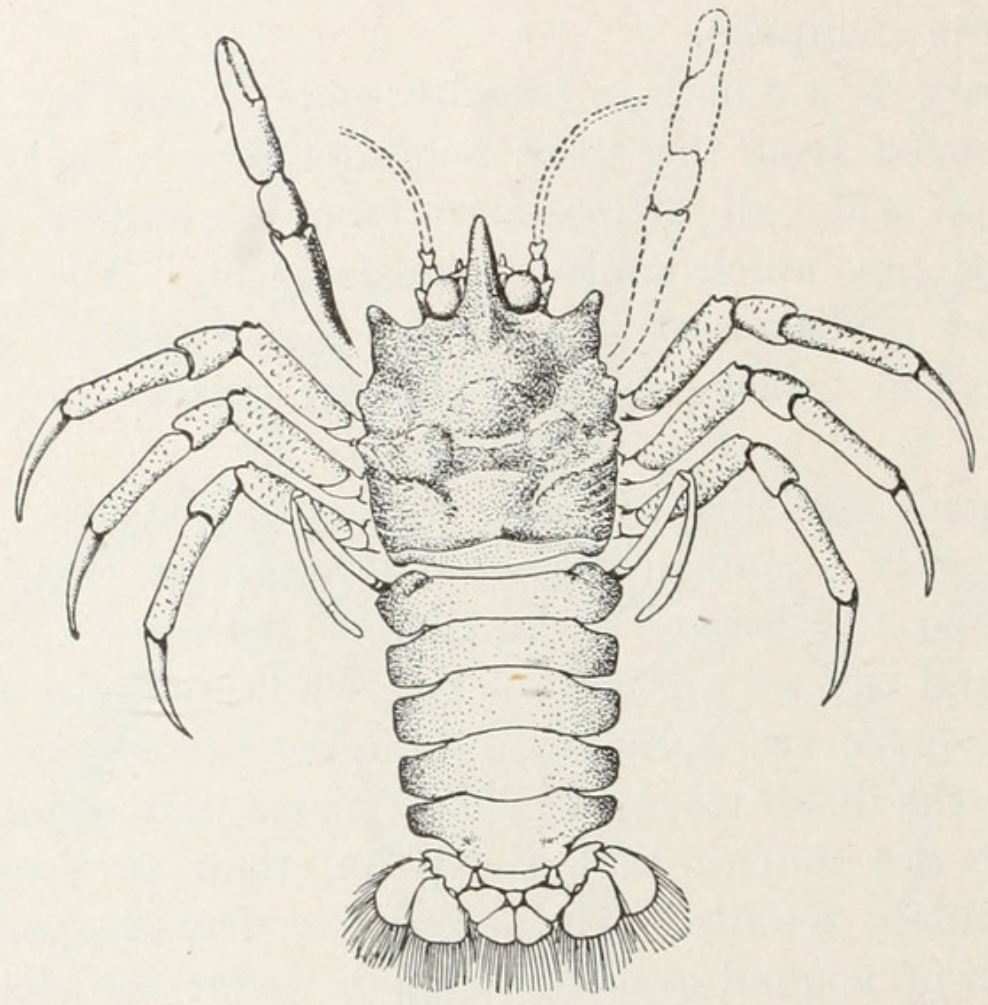

Fig. 25.-MUNIDOPSIS ESPINIS, $\times 2 \frac{1}{3}$.

This species is altogether without spines, with the exception of two on the merus of the maxillipeds.

The carapace is $7.5 \mathrm{~mm}$. in each dimension.

Locality.-Albatross, station 2351, 426 fathoms, off Yucatan.

Type-Cat. No. 20559, U.S.N.M.

\section{MUNIDOPSIS EXPANSA, new species.}

The front extends forward horizontally and ends in two points and a sharply upturned rostrum. The carapace is very broad, and, excepting on the margin, is altogether devoid of spines; the surface is rather crowded with short, semicircular, raised lines; the antero-lateral angles are formed by triangular teeth, the points of which are directed forward; behind the angles are two teeth on a small lobe and a third one at about the middle of the margin. The merus of the maxillipeds is unarmed. The distai margins of the meral joints of both the chelipeds 
and ambulatory legs are armed with tubercular spines; the chelipeds are much shorter than the body.

Length of the body from the tip of the rostrum to the end of the telson, $52 \mathrm{~mm}$.; length of the chelipeds, $30 \mathrm{~mm}$.; length of carapace from the sinus behind the eye, $20 \mathrm{~mm}$.; breadth in the middle, $22 \mathrm{~mm}$.

Locality. - Station 2663, 421 fathoms, off Florida.

Type.-Cat. No. 20561, U.S.N.M.

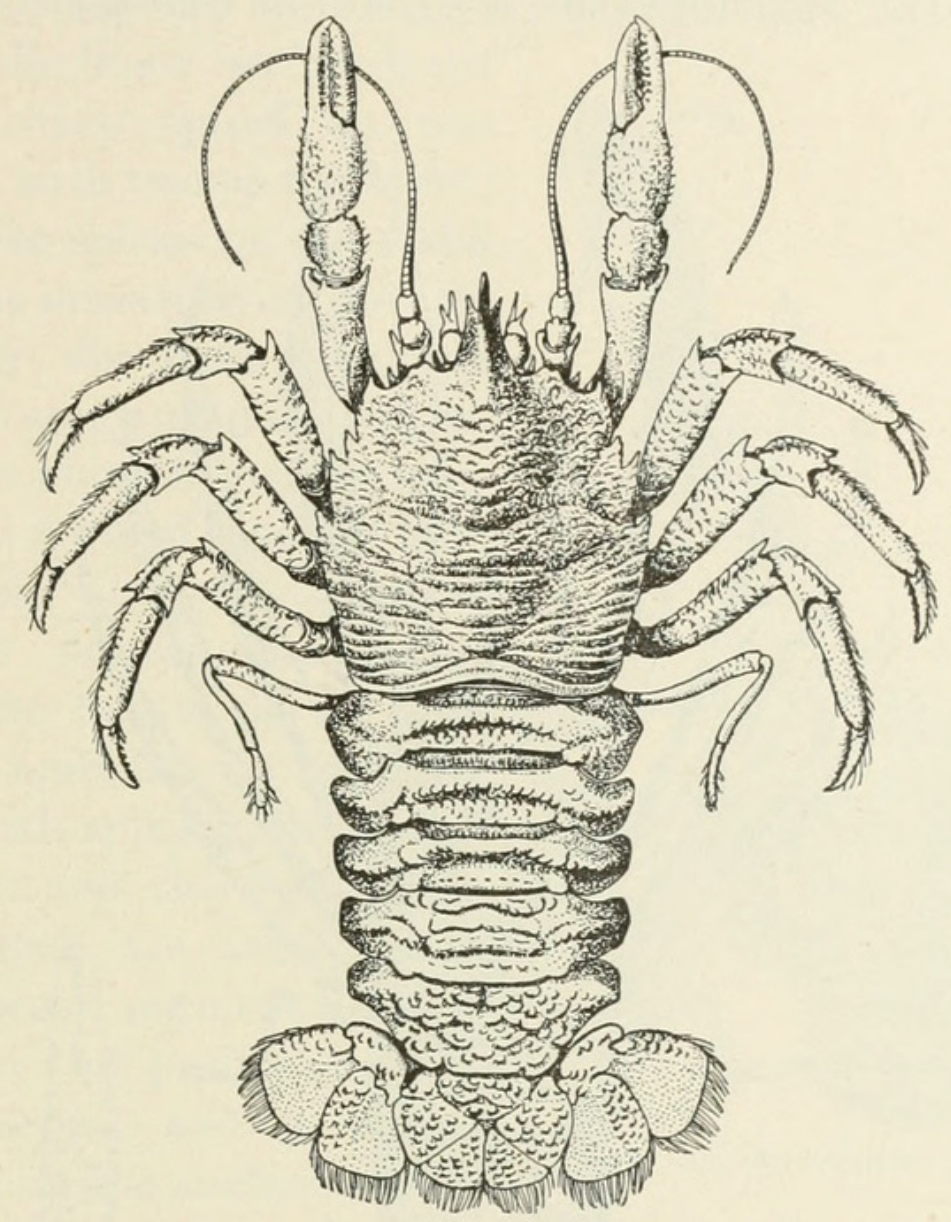

FIG. 26.-MUNIDOPSIS EXPANSA, $1 \frac{1}{9}$.

MUNIDOPSIS GILLI, new species.

The rostrum projects forward and ends in two horizontal points and a sharply upturned rostral point, as in Galicantha. The portion of the front behind the rostrum is unarmed. The lateral margins are very uneven. A lobe bearing a small spine marks the antero-lateral angles; behind the angle is a lobe with two points, followed by a sinus, then another short spine or point. There are eight or more small tubercular granules on the posterior border and numerous similar granules scattered over the carapace and legs The different areolations are protuberant; the gastric area is surmounted by three spines, placed at the points of an equilateral triangle; there are two short spines on the cardiac area. The merus of the maxillipeds is armed with three spines; the first is very stout at the base, the second is slender, the third is short.

Proc. N. M. vol. xxvi-02-20 
The chelipeds are shorter than the body. The second, third, and fourth segments of the abdomen are each armed with a single spine.

Length of body from the rostrum to the end of the telson, $58 \mathrm{~mm}$.; length of carapace from behind the eyes, $24 \mathrm{~mm}$.; breadth, $19.5 \mathrm{~mm}$.

Locality.-Albatross, station 2629, 1,169 fathoms, off Bahama Islands.

Type.-Cat. No. 20562, U.S.N.M.

Named for Dr. Theodore Gill, associate in zoology, U. S. National Museum.

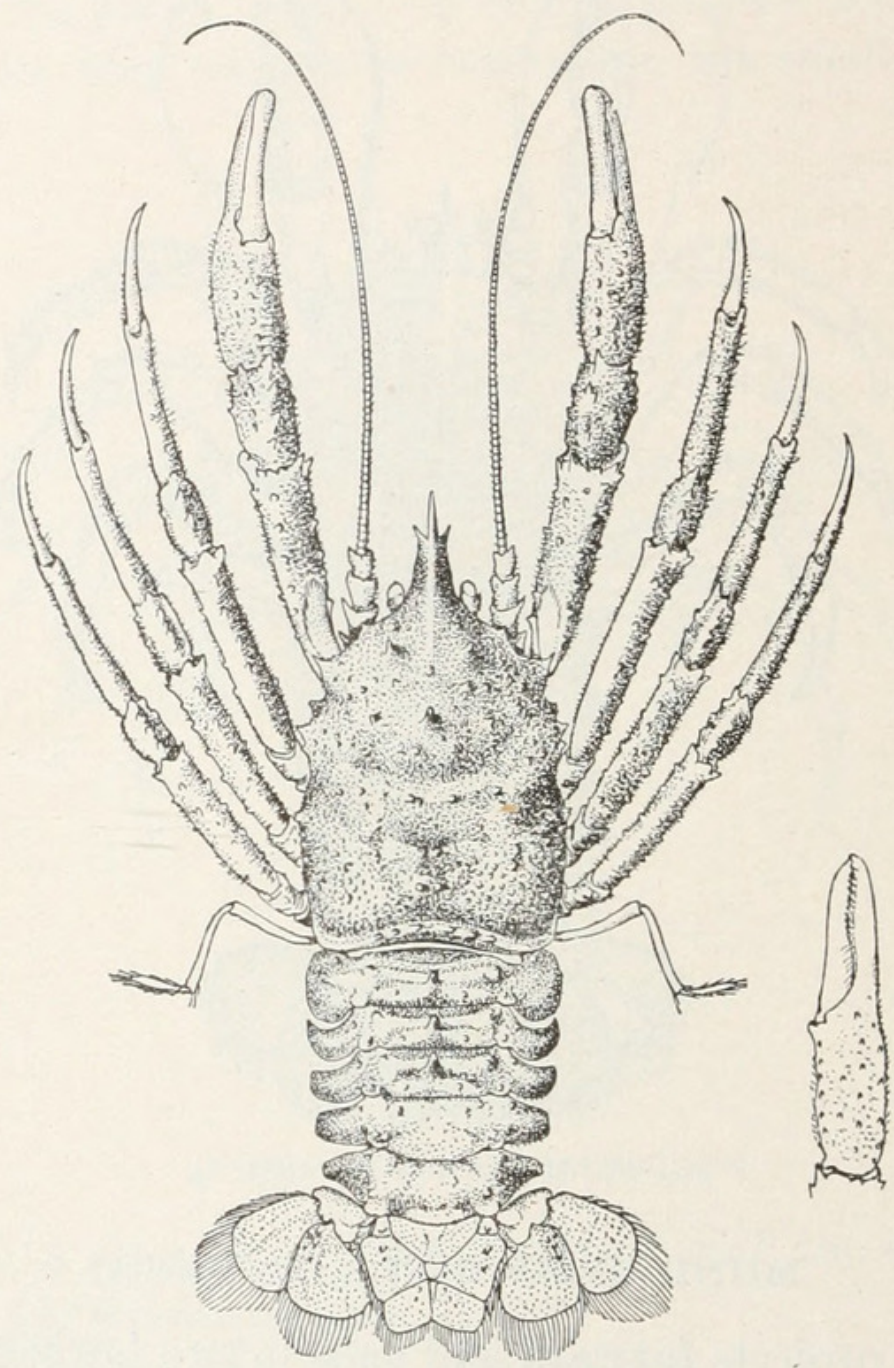

Fig. 27.-MUNIDOPSIS GILLI, $\times 1$.

MUNIDOPSIS HASTIFER, new species.

The rostrum is rather broad, its sides are arcuate, the apex is acute, and the margin is cut into small serrate teeth; a prominent carina runs from the apex to the highest part of the gastric protuberance. The sides and front meet in an obtuse angle which is armed at the apex with a small spine.

The front runs forward from the angle to a point almost under the eye, then back around the eye to the rostrum, leaving the eye in a semicircular orbit in which the eye moves slightly.

The carapace is about one-sixth longer than broad, the areolations are protuberant and curiously armed with compressed spines, many 
having sharp procurved points, especially those near the sides of the carapace; the gastric area has two large spines of this nature and numerous smaller ones. There are two on the median line on the cardiac area. The posterior margin of the carapace is raised, the middle th ird is free from spines, but on either side of this space is a pair, rather large and procurved.

The chelipeds are about three times the length of the carapace, not including the rostrum; the merus is set with rows of elongated granules, the middle inner surface is set with three sharp spines on one cheliped and with two on the other; there are three spines on the distal margin. The armature of the carpus is similar; the palm is thickly set with small spiny granules below, large ones run along the upper margin in a well-formed line. There is a line of hair along the ridge of the movable finger; the hiatus formed by the fingers is set with hair. The ambulatory feet are thickly set with spiny granules.

The second and third segments of the abdomen are armed with spines, the second segment has two spines in a central position on the posterior margin, and a paired group of two on the surface nearer

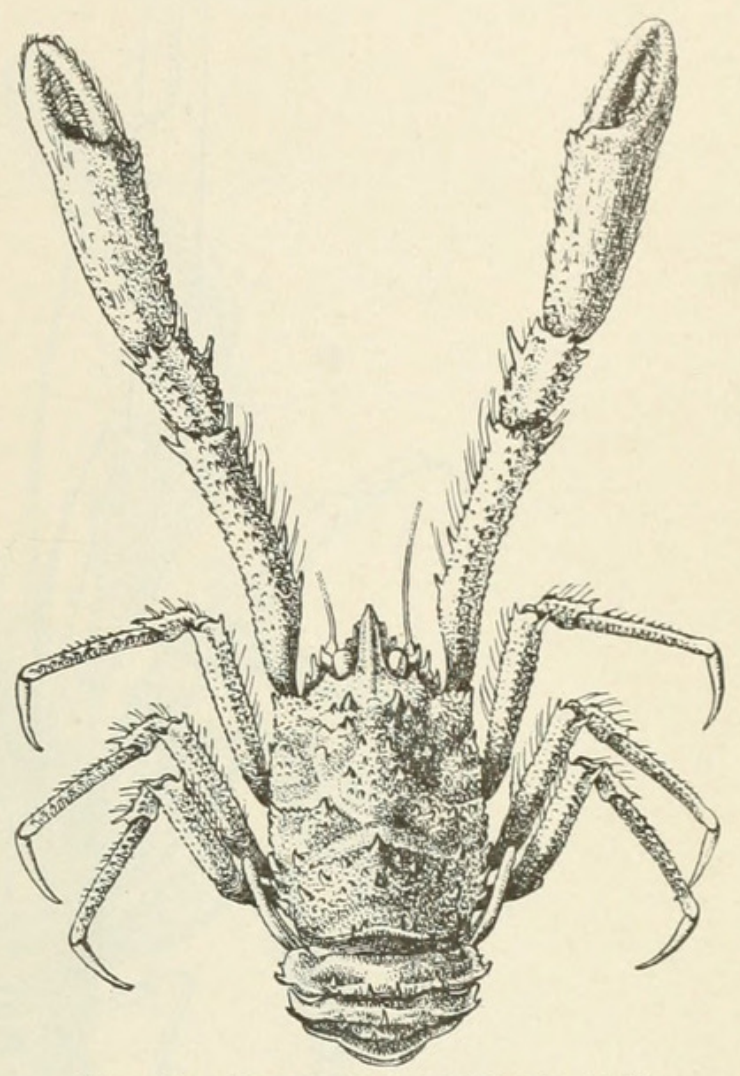

FIG. 28.-MUNIDOPSIS HASTIFER, $\times 2 \frac{2}{3}$. the side; the third segment has a spine on the median line on the anterior margin and a pair separated by the line on the posterior margin, also smaller spines near the sides.

The carapace of the largest specimen, a female without eggs, is 9.5 $\mathrm{mm}$. in length measured from the orbit, and $8 \mathrm{~mm}$. in width; the chelipeds are $28 \mathrm{~mm}$. in length, the palm at the base of the dactyl is $3.2 \mathrm{~mm}$. in width, the fingers are $4.5 \mathrm{~mm}$. long, and the palm $6.8 \mathrm{~mm}$.

Three specimens were taken at Albatross station 3697 in $265-120$ fathoms, off Honshu Island, Japan.

Type.-Cat. No. 26164, U.S.N.M.

MUNIDOPSIS MINA, new species.

The rostrum is about as long as broad, measured from its base to the base of the lateral points. The distance between the lateral points is about five-eights of the length of the base. The carapace is elongated; the sides are slightly arcuate and armed with four short spines. There are two short spines on the gastric area, as in M. tridens 
A. M. Edwards. The merus of the maxillipeds is armed with four spines. The first is very broad, but sharp pointed; the second is slender; the third and fourth are short. The merus of the right cheliped has a row of small spines on the upper margin and three or four large spines on the inner surface. The carpus is armed on the distal margin with five spines. The palm is slender, a little compressed, smooth on the sides, granular above and below.

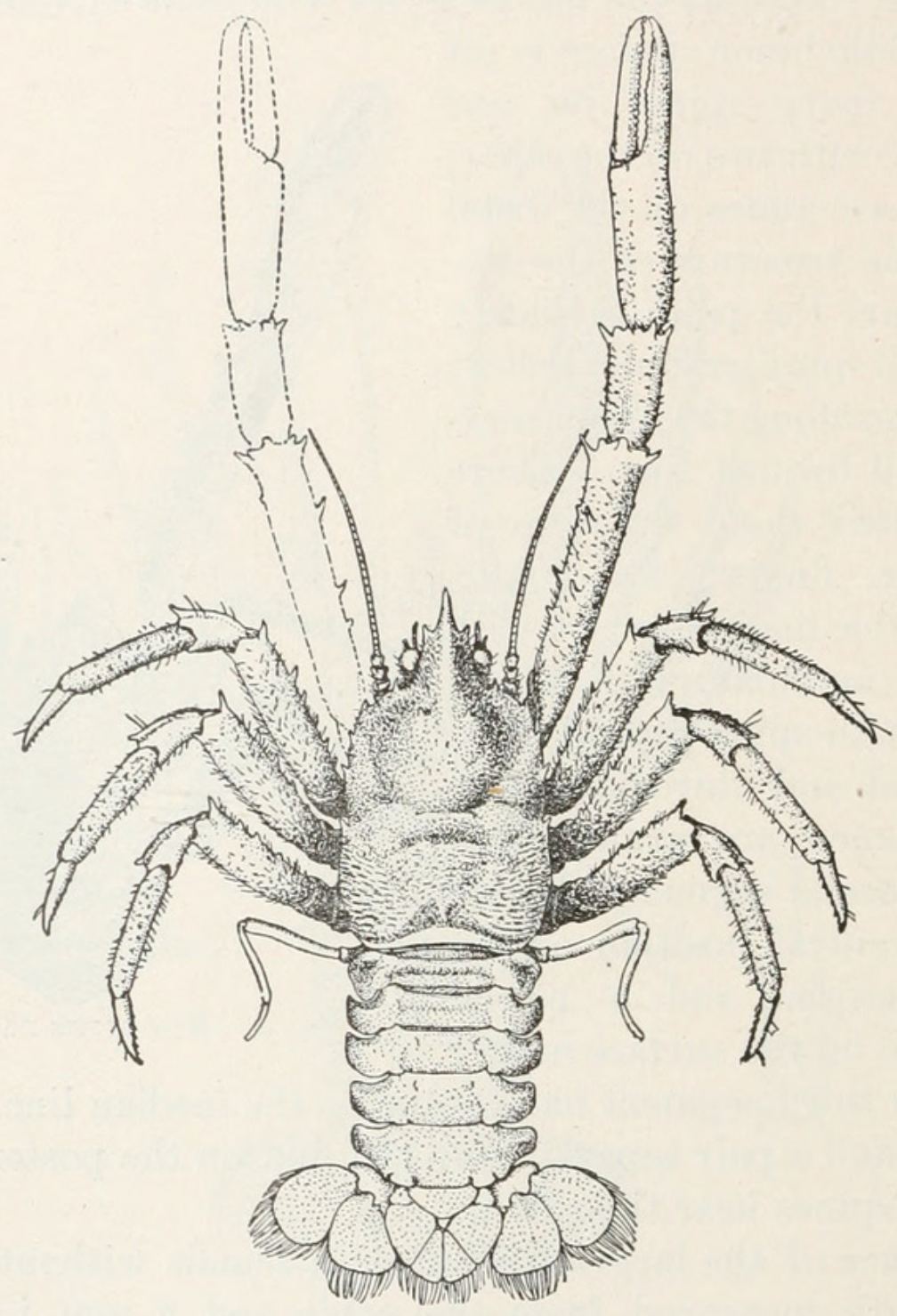

Fig. 29.-MUNIDOPSIS MINA, $\times 1 \frac{1}{3}$.

Length of body from the tip of the rostrum to the end of the telson, $40 \mathrm{~mm}$. ; length of carapace from the front to the posterior margin, $16 \mathrm{~mm}$; width of carapace, $12.5 \mathrm{~mm}$.

Locality.-Albatross station 2818, 392 fathoms, off Galapagos Islands. Type.-Cat. No. 20557, U.S.N.M.

\section{MUNIDOPSIS MODESTA, new species.}

The rostrum is broad; the rostral point is very much longer than the lateral points at its base.

The antero-lateral and other marginal spines are small for this section of the genus. The carapace is inconspicuousiy set with short hair; 
the hair on the chelipeds and ambulatory legs is long, but not at all dense. There are no spines on the carapace.

The inferior margin of the merus of the maxillipeds is armed with two short, sharp-pointed teeth. The spines on the merus of the chelipeds vary in number, in most specimens there are four or five on the inner surface. There is but a single true spine on the carpus, situated at the inner angle. The hands are smooth; the palms are rather broad. The ambulatory feet are almost unarmed; the terminal spines of the meral and carpal joints are the most conspicuous.

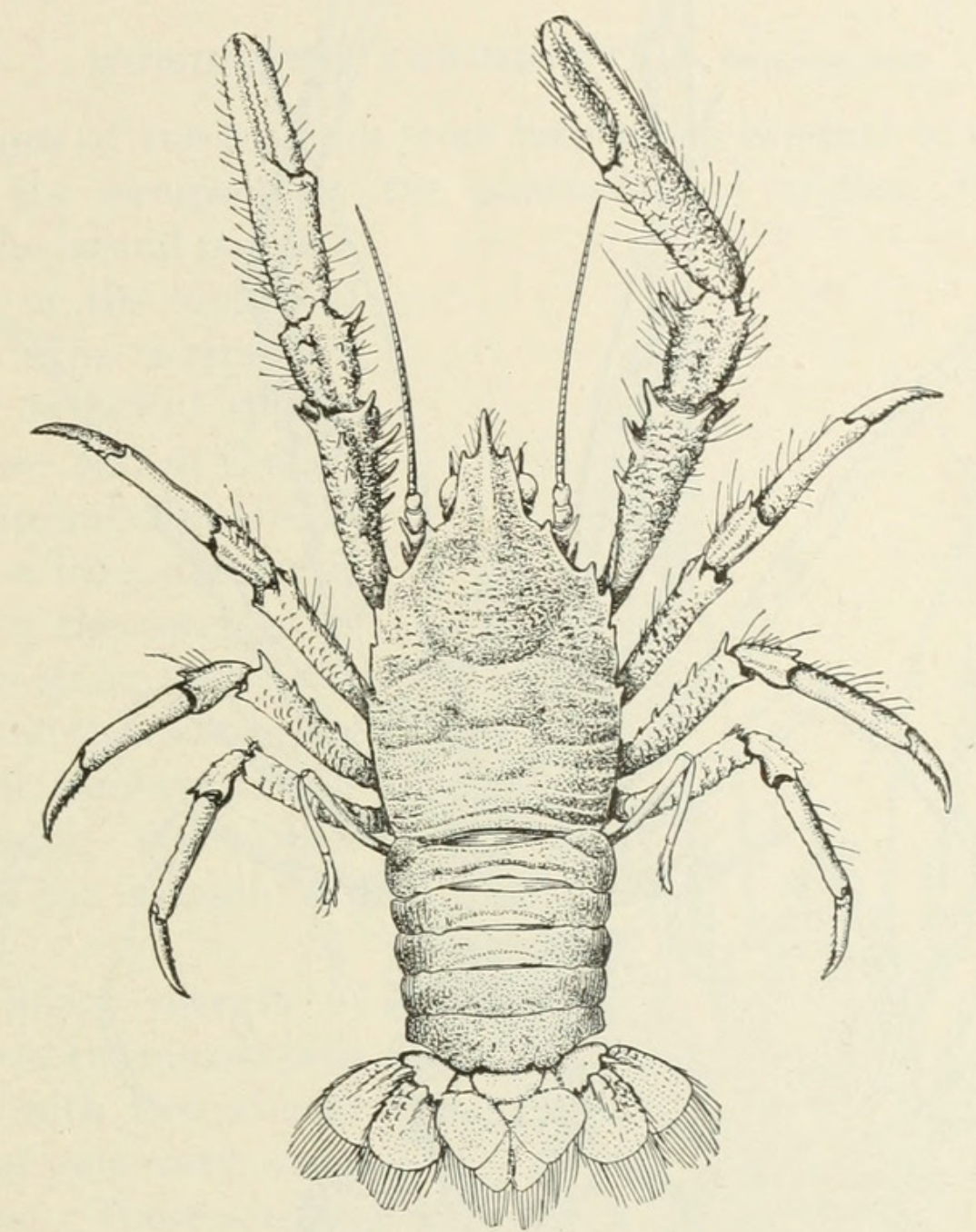

Fig. 30.-MUNidopsis MODE, a, $\times 3$.

Length of the carapace from the front behind the eyes, $8.5 \mathrm{~mm}$.; breadth of carapace, $7 \mathrm{~mm}$.; length from the tip of the rostrum to the end of the telson, $22 \mathrm{~mm}$; length of chelipeds, $22 \mathrm{~mm}$.

Locality.-Albatross station 2818, 392 fathoms, off Galapagos Islands. Type.-Cat. No. 20553, U.S.N.M.

A number of specimens, one small female with eggs.

\section{MUNIDOPSIS OPALESCENS, new species.}

The rostrum is sharp pointed, triangular in section, armed on the sides with three or four spines irregularly placed. The carapace is subquadrangular in shape; the antero-lateral angles are armed with a 
single spine, which stands out diagonally and curves forward. The areolations are very protuberant; three spines arise from the gastric area, a transverse pair near the front and one on the median line farther back. There is a large spine on the cardiac area, followed by one or more smaller ones; three spines on the post-branchial area are in line near the margin; behind the antero-lateral angles there are three spines on the margin. The posterior border is armed with six or

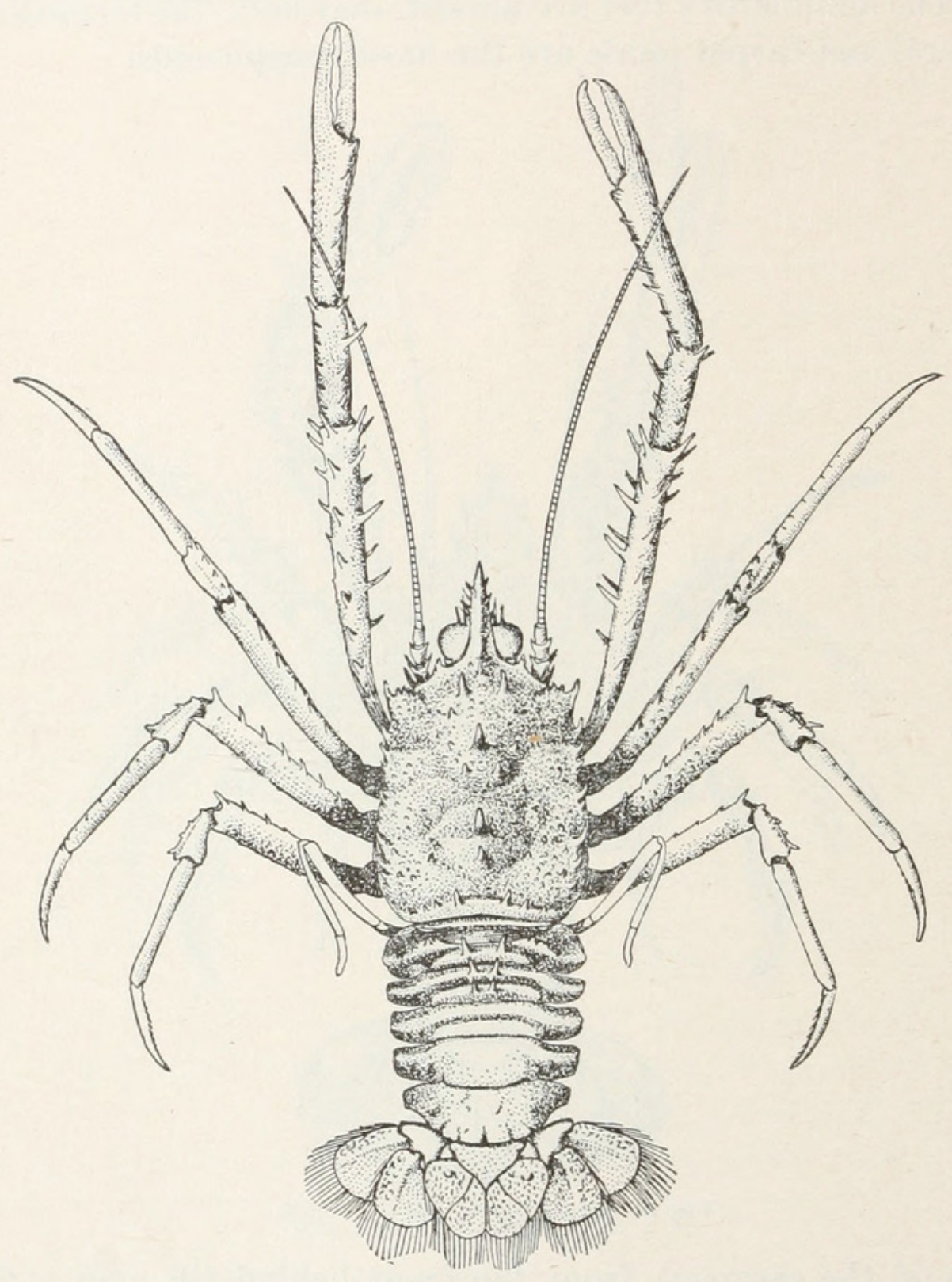

FIG. 31.-MUNIDOPSIS OPALESCENS, $2 \frac{2}{3}$.

more spines. In addition to the spines enumerated there are a variable number of spinules and spiny granules scattered over the surface.

The second segment of the abdomen is armed with two large spines; anterior to these at the sides are one or more paired spinules. The third segment is armed with four spines, a pair on each of the two ridges; the anterior pair are the larger. The inferior margin of the merus of the maxillipeds is armed with four spines, the third is usually the shortest; the superior margin has three or four small denticles. 
The chelipeds are slender; the spines on the merus are distantly placed in three principal rows; there is a very large spine at the inner angle of the carpus; many smaller ones are arranged in three rows. The palm has a single row of spines on the superior margin; the fingers are short. Color very light, with briliant opalescent reflections.

Length of a female from the margin behind the eyes to the end of the telson, $20 \mathrm{~mm}$.; length of chelipeds, $27 \mathrm{~mm}$.

Locality.-Albatross station 2781 in 348 fathoms and 2785 in 449 fathoms, off Patagonia.

$$
\text { Type.-Cat. No. 20558, U.S.N.M. }
$$

MUNIDOPSIS TENUIROSTRIS, new species.

The length of the rostrum from base to tip is equal to one-half the width of the carapace at the antero-lateral angles; the distance between the lateral points is two-fifths of the length of the base. The carapace is hairy and devoid of spines; the anterior half of the lateral margin is straight in the male and a little arcuate in the female; the margin between the spine above the antennæ and the base of the rostrum is transverse; the antero-lateral and other spines of the margin are subequal.

The inferior margin of the merus of the maxillipeds is armed with two slender spines and one very short conical one. There are two rows of spines on the merus of the chelipeds, with two large spines between them; the hands are flattened and a little elongated.

Length of the carapace from the margin behind the eye to the middle of the posterior margin is $11 \mathrm{~mm}$.; breadth of carapace, $9 \mathrm{~mm}$.; length of cheliped, $32 \mathrm{~mm}$.

Locality.-Albatross station 2415, 440 fathoms, off the coast of Georgia.

Type.-Cat. No. 20560, U.S.N.M. 


\section{MUNIDOPSIS TOWNSENDI, new species.}

The carapace is a little longer than wide, measuring from the base of the rostrum. In shape it is almost as quadrate as $M$. quadratus Faxon. The areolations are protuberant, and the entire surface is thickly set with tubercular granules subequal in size. These granules extend to the end of the rostrum. The rostrum is short and narrow, extending but little beyond the eyes. A tooth on the margin behind the antennæ forms the outer angle of the orbital sinus.

The posterior margin is armed with granules of the same size and character as the surface of the carapace.

The second and third segments of the abdomen are armed each with a large tubercle; the tubercles and the surfaces of the segments are

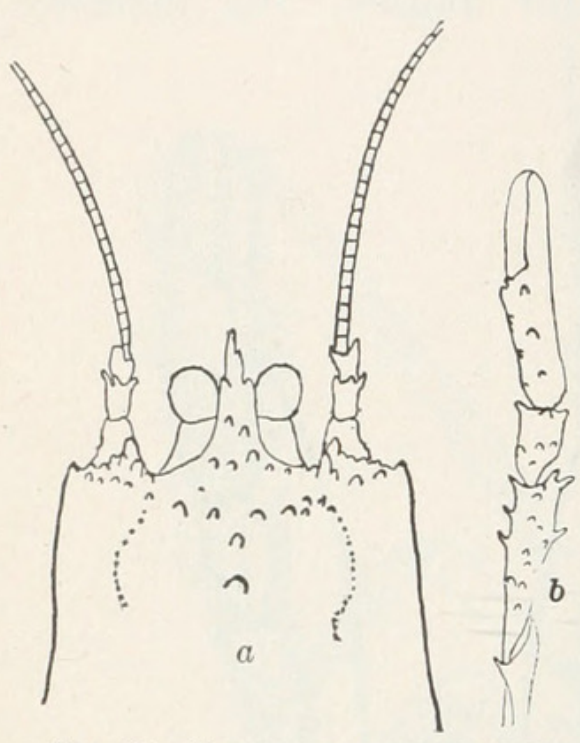

FIG. 33.-MUNIDOPSIS TOWNSENDI, $a \times 3 \frac{1}{2}, b \times 2$. covered with the same granulations as the carapace; the other segments are smooth.

The upper surface of the merus of the cheliped is armed with about fifteen short and very stout spines; the lower surface is semicylindrical and smooth; the carpus is armed with nine to twelve short tubercles.

The palm is rather longer than the fingers and a little narrower. On the outer surface, in line with the gape of the fingers of the right hand, are the three largest spines on the cheliped; near the crest and parallel with the line of large spines is a row of very much smaller ones. The fingers are compressed, thin, and evenly toothed on the prehensile edges. On the left hand the three spines behind the gape are replaced by six smaller ones, and one or two of the parallel rows are hardly indicated.

The merus of the ambulatory feet is tubercular or spiny on the distal half, the carpus is tubercular, and the propodus is smooth with the exception of a line of three to four conical spines on the upper surface.

The dactyls are short and much curved. The merus of the maxillipeds is armed with two short, stout spines.

Length of earapace, from base of rostrum, $7 \mathrm{~mm}$.; greatest width, $8 \mathrm{~mm}$.

Named for Mr. C. H. Townsend, who served as naturalist on the U. S. Fish Commission steamer Albatross.

The type is a female with eggs from Albatross station 2818.

Type.-Cat. No. 26167, U.S. N. M. 
MUNIDOPSIS VERRILLI, new species.

The rostrum is slender and triangular in cross section; the upper margin runs back as a carina to a point behind the spines of the gastric region; the rostrum is slightly bent upward. The front from the base of the rostrum to a point under the anterolateral spine is nearly straight and is at an angle of about 45 degrees to the median line. The eyestalks are armed with two spines, of which the inner is much the longer. The carapace is iridescent; the short and rather elevated rugæ are hairy. The abdomen is unarmed.

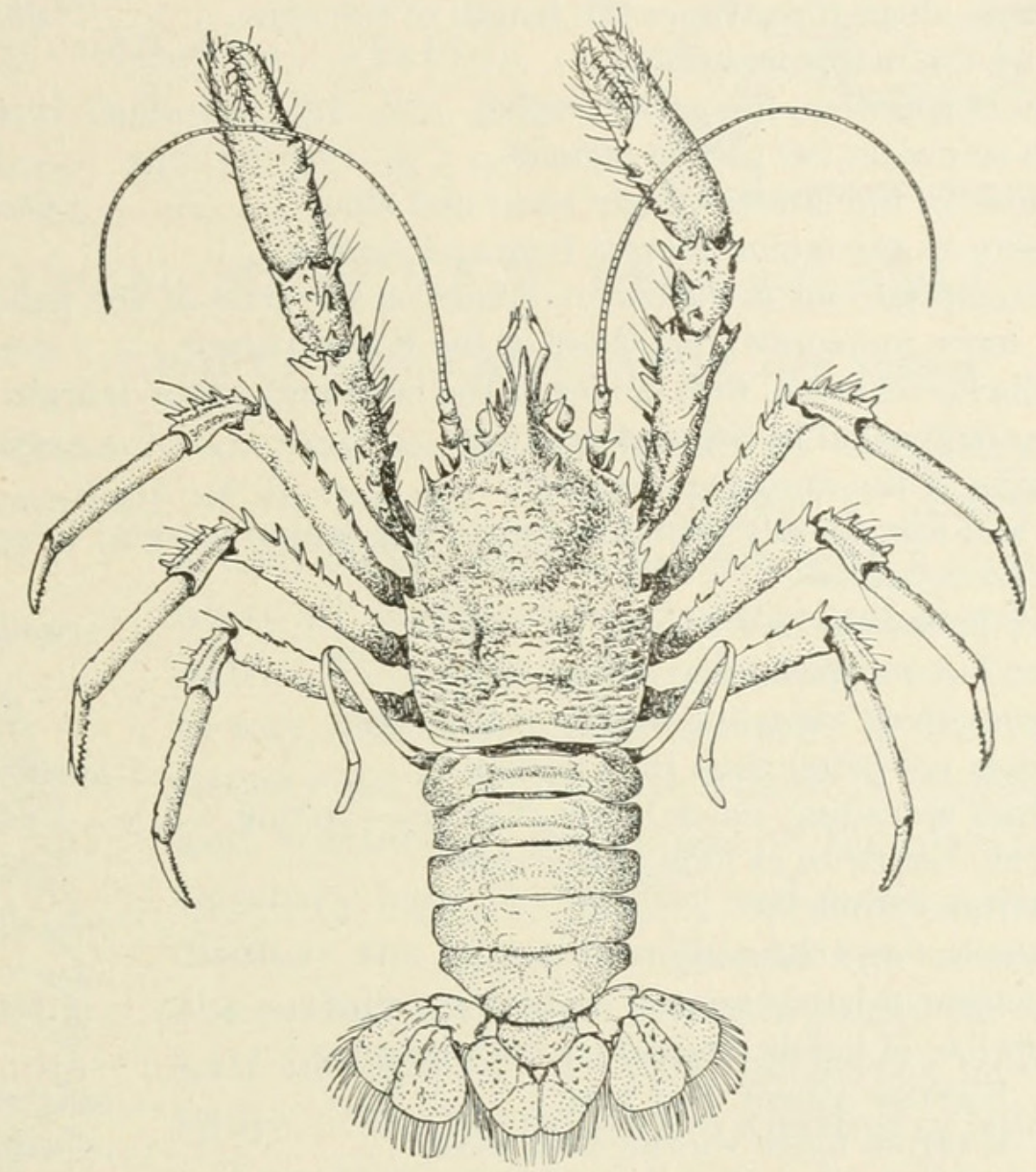

Fig. 34.-MUNidopsis VETiRILLI, $\times 1 \frac{2}{3}$.

The merus and carpus of the ambulatory legs are spiny. The merus of the chelipeds is triangular in cross section; it has four spines on the upper ridge and two on the inner; there are five or six spines on the carpus, and two prominent spines on the crest of the palm; the prehensile edges of the fingers are evenly dentate.

This species is related to M. brevimana Henderson and to M. citiata Wood-Mason and to $M$. nitida Milne-Edwards.

Taken by the Albatross at stations 2919 and 2923, off southern California.

Named for Prof. A. E. Verrill.

Type.-Cat. No. 20656, U.S.N.M. 


\section{Genus UROPTYCHUS Henderson.}

\section{KEY TO THE SPECIES OF UROPTYCHUS EXAMINED.}

a. Lateral margin of the carapace armed with spines or spinules.

b. Merus without spines, except at the articulation with the carpus.

c. Rostrum but little longer than the eyes.

d. Gastric region smooth .............................. . . . . . 330

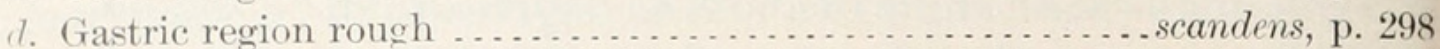

c. Rostrum about twice the length of the eyes.............. granulatus, p. 293

b. Merus spiny.

c. Spines on the merus few.

d. Rostrum broad, triangular, not twice as long as the eyes....minutus, p. 296

d. Rostrum about three times the length of the eyes .......... spiniger, p. 298

c. Spines on the merus numerous.

d. Without spines on the gastric region ................... . . .lus, p. 331

d. With spines on the gastric region.

e. Spines on the lateral margin short and stout ........... . pubescens, p. 332 $e$. Spines on the lateral margin long and slender.

$f$. Chelipeds long and slender; spines on the crest of the palm larger and more numerous than those of the lower margin .... . spinosus, p. 333

$f$. Chelipeds stout, with spines of the erest and lower margin longer and about equal in size and number .................. princeps, p. 296

a. Lateral margin of the carapace unarmed.

b. Carapace and legs densely spinulose (including lateral margin) .. rugosus, p. 333

b. Carapace not spinulose.

c. Carapace pubescent ................................. capillatus, p. 293

c. Carapace not conspicuously pubescent.

d. Rostrum about twice the length of the eyes.

e. Cornea not larger than the eyestalk .................jamaicensis, p. 294

e. Cornea spreading, much larger than the eyestalk .......... nitidus, p. 332

d. Rostrum not twice as long as the eves.

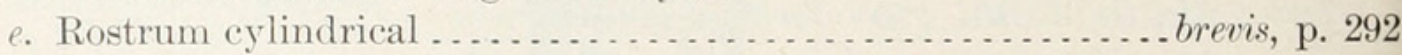

e. Rostrum flat, triangular.

f. Outline of hands arcuate on both margins............. . uncifer, p. 333

$f$. Outline of hands straight on both margins.

g. Rostrum longer than eyes .................... occidentalis, p. 332

g. Rostrum much shorter than eyes ................. scambus, p. 297

UROPTYCHUS BREVIS, new species.

The rostrum is short, subcylindrical, and blunt. The only armature of the carapace is at the antero-lateral angles, from which a fingerlike tubercle extends directly forward.

The carapace is remarkable for its dimensions, being much broader than long; the broadest portion is near the posterior margin; the front is about one-half the breadth; the sides are immarginate.

The merus of the maxillipeds is unarmed. The merus of the cheliped is cylindrical, armed at the distal upper angle with a single small spine; the carpus is a little compressed, with a row of 5 small tubercles on the upper margin and a spine and 2 tubercles on the distal border. The palm is compressed to a thin crest above; the crest is 
serrate; the fingers touch only at the tips; a tubercle on each extends across the hiatus. The propodal joints of the ambulatory legs are flattened and curved, forming more than a semicircle in connection with the curved dactyls.

Length of the carapace from the margin behind the eyes to the end of the median line, $5.5 \mathrm{~mm}$.; breadth, $6.8 \mathrm{~mm}$.; length of rostrum, $1.5 \mathrm{~mm}$.

Locality.-Albatross station 2351 in 426 fathoms, lat. $22^{\circ} 41^{\prime}$ $00^{\prime \prime} \mathrm{N}$.; long. $84^{\circ} 16^{\prime} 30^{\prime \prime} \mathrm{W}$., off Yucatan.

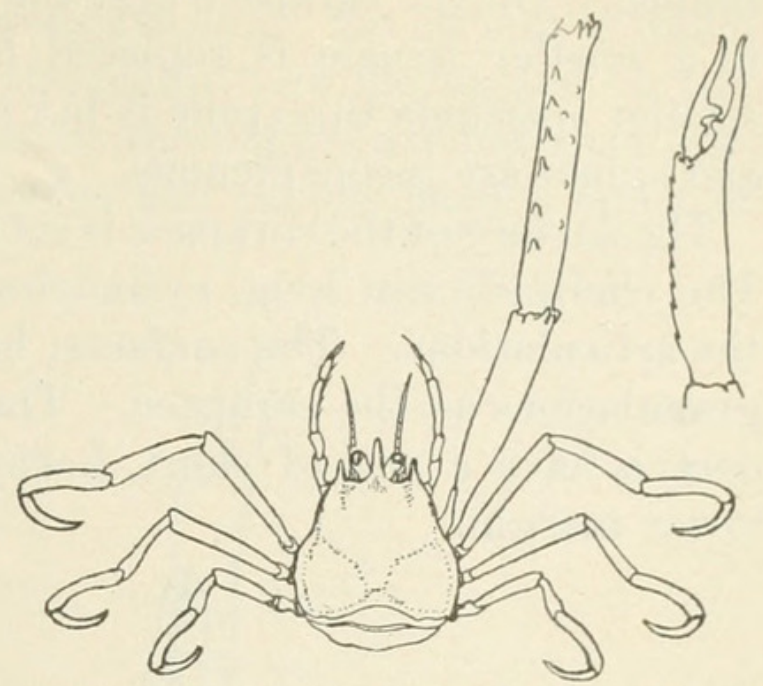

FIG. 35.-UROPTYCHUS BREVIS, $\times 1$ ?

Type.-Cat. No. 20566 U.S.N.M., female with eggs.

UROPTYCHUS CAPILLATUS, new species.

The rostrum is as long as the carapace; its breadth at the base is equal to one-balf of its length. The carapace is broader than long,

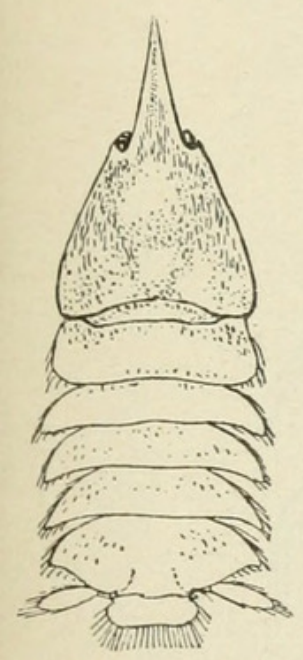

Fig. 36.-UROPTYCHUS CAPILLATUS, $\times 3 \frac{3}{4}$. armed on the lateral margin with a number of spinules; all surfaces are granular and covered with short hair. This species is much nearer to $U$. mugosus than to any other in the collection; it differs in having a dense coat of short hair where in rugosus it is long and scattering; the spines of the margin of the ambulatory legs are smaller and more numerous in capillatus; the upper margins of the propodal joints of the ambulatory legs are spiny only on the proximal half in rugosus. In this species the whole margin is spiny. The chelipeds are wanting in both specimens.

Length of carapace, $3 \mathrm{~mm}$.; breadth, $4 \mathrm{~mm}$.; length of rostrum, $3 \mathrm{~mm}$.

Locality.-Albatross station 2353 in 167 fathoms, lat. $20^{\circ} 59^{\prime} 00^{\prime \prime} \mathrm{N}$., long. $86^{\circ} 23^{\prime} 00^{\prime \prime} \mathrm{W}$.

Type.-Cat. No. 20565 U.S.N.M.

UROPTYCHUS GRANULATUS, new species.

The rostrum of a large female is $5 \mathrm{~mm}$. long, is broad at the base, and sharp at the apex. It is slightly depressed, in conformity to the curve of the convexity of the carapace; it is deeply concave at the base. The antero-lateral angles are armed with stout spines. Near this is a smaller spine at the outer angle of the broad and deep orbital sulcus. The lateral margins of the carapace are very strongly arcuate and unevenly serrate. There is a spine on the margin behind the 
anterior branch of the cervical depression and one behind the posterior branch. On the carapace near the first spine there is a tubercle which in a smaller female is replaced by a spine; in a third and much smaller specimen this spine is but slightly indicated and the serrations and spines are inconspicuous.

The surface of the carapace is set with large, well-separated granules. The chelipeds are long, cylindrical, and free from spines, except at the articulations. The surfaces, however, have the same character of granulations as the carapace. The ambulatory legs are smooth; the dactyls have a row of short, horny teeth, which form a comb on the lower margin.

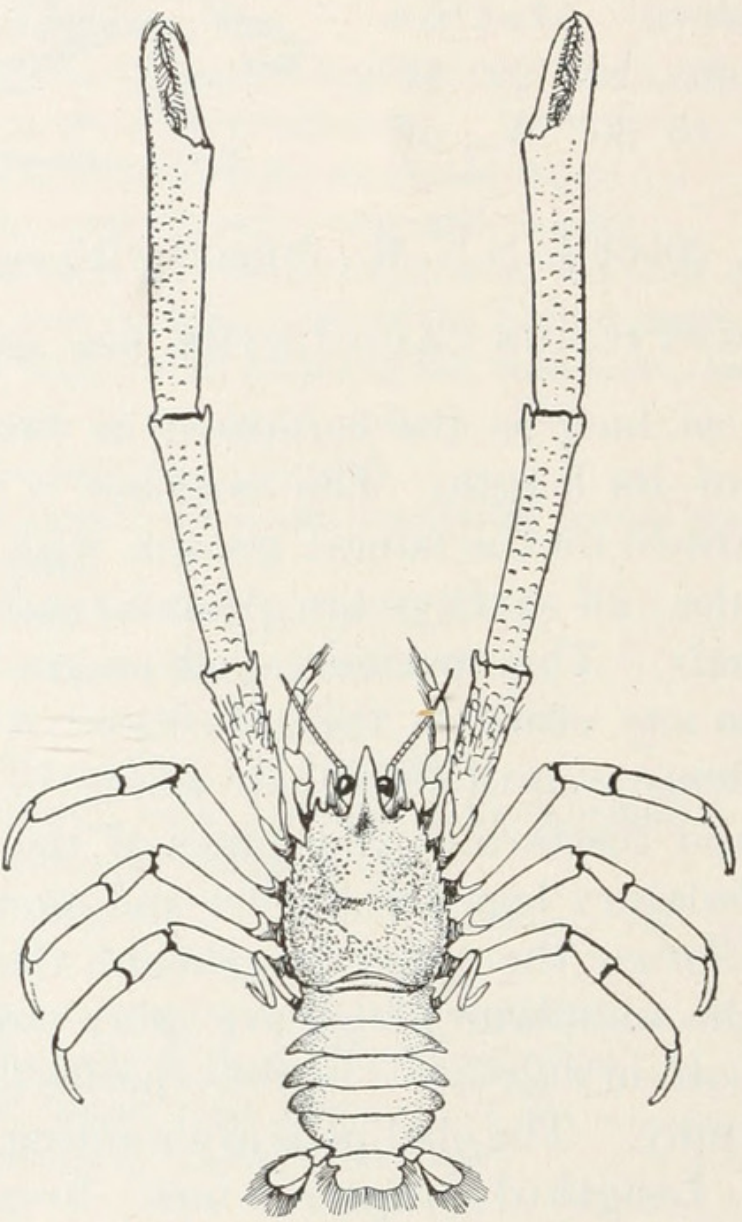

Fig. 37.-UROPTYCHUS GRANULATUS, $\times 1$.

Length of carapace, $11 \mathrm{~mm}$.; breadth between the antero-lateral angles, $7 \mathrm{~mm}$; a little behind the middle, $12 \mathrm{~mm}$; at the posterior margin, $10 \mathrm{~mm}$.; length of chelipeds, $59 \mathrm{~mm}$.; of the palm, $18 \mathrm{~mm}$.; of the fingers, $8 \mathrm{~mm}$.

Taken by the Albatross at station 2818 in 392 fathoms, Galapagos Islands. Three females, the two largest with eggs.

Type.-Cat. No. 20567 U.S.N.M.

UROPTYCHUS JAMAICENSIS, new species.

The rostrum is deeply excavated on the basal half of its surface; it is flat above and below. The surface of the carapace is moderately swollen; the lateral margins are arcuate, ending at the antero-lateral 
angles in a small paired spine. The carapace is smooth, glabrous, and punctuate under a lens. The chelipeds are long; the carpus is much longer than the merus and equal to the palm; both merus and carpus are cylindrical; the palm is compressed; the fingers are less than onehalf the length of the palm; the merus and carpus have a spine at each of the anterior condyles.

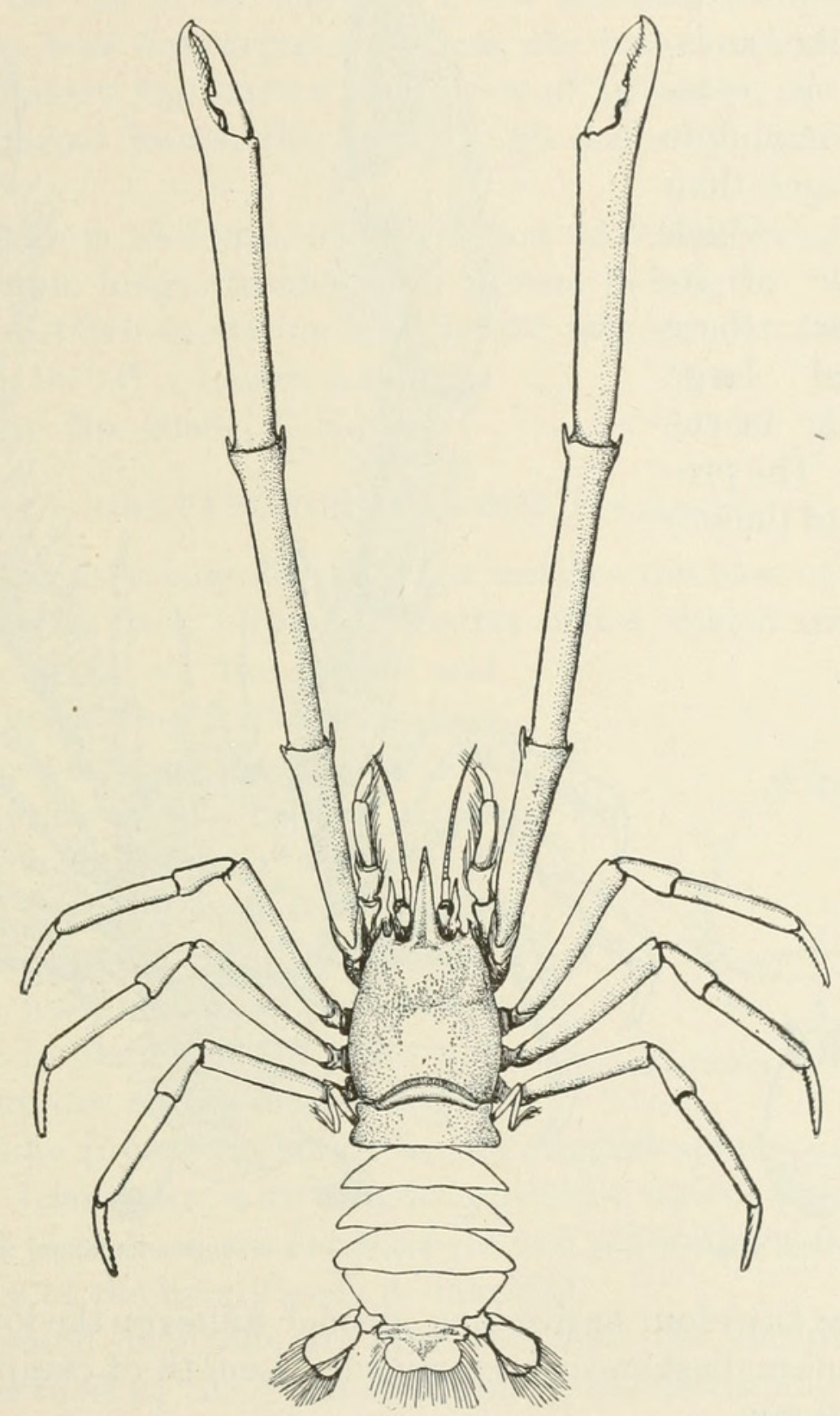

Fig. 38.-URoptychus JAMAiCENSIS, $\times 1 \frac{2}{3}$.

Length of the carapace, $8 \mathrm{~mm}$; greatest breadth, $9 \mathrm{~mm}$.; length of the rostrum from the margin behind the eyes, $5 \mathrm{~mm}$.; breadth of rostrum at base, $2.5 \mathrm{~mm}$.

Locality.-Albatross station 2117 , in 683 fathoms, lat. $15^{\circ} 24^{\prime} 40^{\prime \prime}$ N., long. $63^{\circ} 31^{\prime} 30^{\prime \prime}$ W., Caribbean Sea.

Type-Cat. No. 20568, U.S.N.M. 
UROPTYCHUS MINUTUS, new species.

The rostrum is long, sharp, and broad at the base; the sides are straight. The carapace is broadest near the posterior margin; the lateral margins are armed with six or seven spinules, and converge to a narrow front. The species is remarkable for the large size of the hands. The palm is compressed; the immobile finger is longer than the dactyl, which closes inside of its hooked apex; there are several large spines on the merus and carpus. The propodal joints of the am-

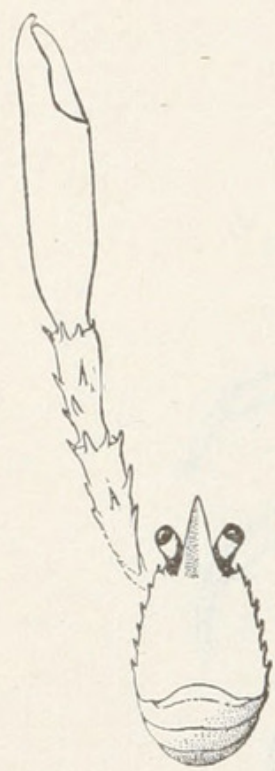

Fig. 39.-URoptychus MINUTUS, $\times 3 \frac{2}{3}$.

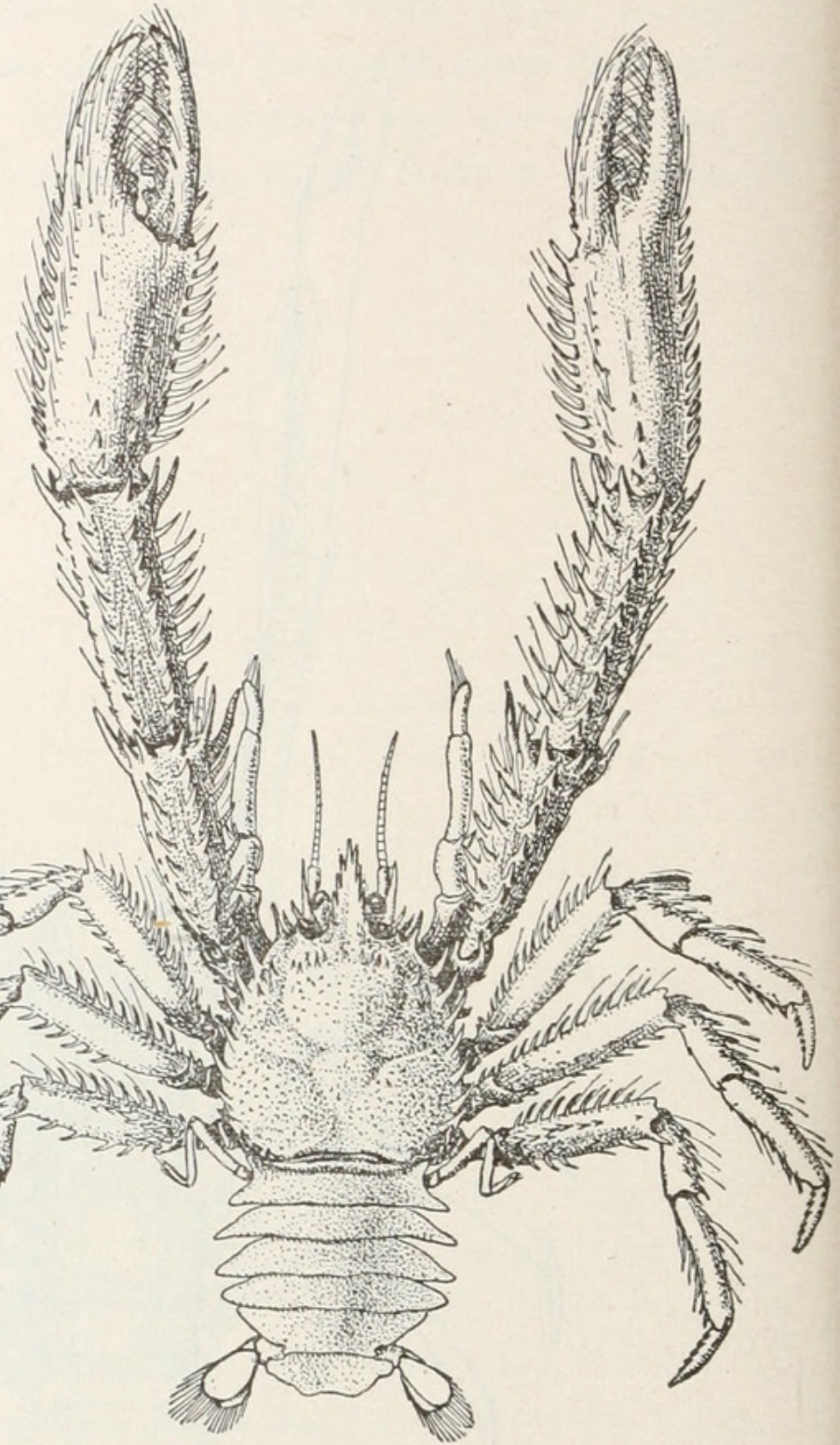

FIG. 40.-UROPTYCHUS PRINCEPS, $\times 1 \frac{1}{3}$.

bulatory legs have four or five long, slender spines on the lower margin.

This is the smallest species examined. Length of carapace, $3 \mathrm{~mm}$.; chelipeds, $10 \mathrm{~mm}$.

Locality.-Albatross station 2120, in 73 fathoms, off Trinidad.

Type.-Cat. No. 7833, U.S.N.M.

\section{UROPTYCHUS PRINCEPS, new species.}

The rostrum is long, sharp pointed, broad at the base and curved downward; four or five small spines lie along its margins irregularly placed. The carapace is broader than long, flattened, armed on the margin with fine, long, slender spines. A row of spines extends across the carapace a little behind the front; the row is interrupted in the middle. There are numerous spinules on the carapace near the margins. 
The upper distal angle of the merus of the maxillipeds is armed with a single spine; the corresponding angle of the following joint with two.

There are four lines of spines on the merus of the chelipeds; the spines near the distal margin are long; there are seven rows on the carpus; the palm is compressed and long; eleven spines on the crest and fifteen on the lower margin; a few spinules are placed on the outer surface near the carpus and crest; the inner surface is smooth.

The ambulatory legs have a single row of spines on the crest of the meral and carpal joints; the meral joints have two additional rows below.

The carapace is $12.5 \mathrm{~mm}$. in length and $13.5 \mathrm{~mm}$. broad. The rostrum is $5.5 \mathrm{~mm}$. long; the chelipeds $55 \mathrm{~mm}$. in length.

Locality.-Albatross station 2752 , in 281 fathoms, lat. $13^{\circ} 34^{\prime} 00^{\prime \prime} \mathrm{N}$., long. $61^{\circ} 04^{\prime} 00^{\prime \prime} \mathrm{W}$., Lesser Antilles.

Type.-Cat. No. 20564, U.S.N.M.

\section{UROPTYCHUS SCAMBUS, new species.}

The rostrum is triangular, its apex reaches the base of the cornea. The front is cut back into semicircular orbits, which are continuous with the rostrum on the inside and nearly so with the finger-like projection at the antero-lateral angles which guard the outer angles of the orbital sinus. The earapace is broader than long, measuring $7 \mathrm{~mm}$. in length to $8 \mathrm{~mm}$. in breadth, it is convex in all directions, and has no marginal or other spines; the surface is glabrous; the sides are prolonged at the antero-lateral angles
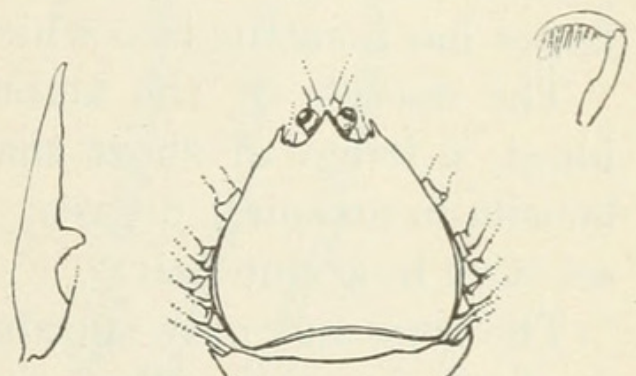

into finger-like processes, which do not suggest spines. In shape the carapace is triangular, with rounded posterior apices and the anterior apex cut off to make room for the eyes and other appendages.

The merus of the maxillipeds is unarmed.

The elongated chelipeds are unarmed, with the exception of some slight projections at the distal margins of the merus and carpus and two tubercles in the gape of the fingers.

The ambulatory feet are cylindrical; the dactyls are subprehensile, and armed beneath with a row of little spines which are hidden by a dense growth of hair.

It will be seen by the figures that this species is very closely related to Uroptychus brevis of the Antillian region; the subprehensile dactyls common to both, in conjunction with the proportions of the carapace, might well enough warrant generic distinction, if the genus as at present constituted was overerowded, which can hardly be claimed for it. 
The type and only specimen is a female with eggs, dredged by the Athatross off Honshu Island, Japan, at station 3706, in 337 fathoms.

Type.-Cat. No. 26165 , U.S.N.M.

\section{UROPTYCHUS SCANDENS, new species.}

The rostrum is about $1.2 \mathrm{~mm}$. in length, narrow, pointed, concave above. The posterior line of the orbital sinus is but little behind the line of the antero-lateral angles. 'The eyes

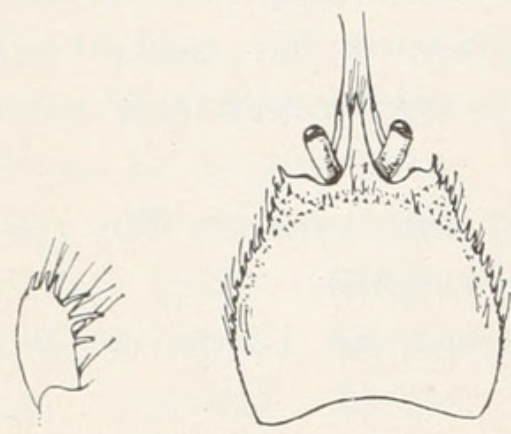

Fig. 42.-URoptychUS SCANDENS, are cylindrical and about $1 \mathrm{~mm}$. in length.

The carapace is $4 \mathrm{~mm}$. in length, measured from the orbit to the posterior margin at the median line and $4.5 \mathrm{~mm}$. in breadth.

The lateral margins are spinulose; a few spinules are placed along the side of the gastric region, replaced on the front of the region by granules. The antero-lateral angles are armed with spines a little

larger than those of the margin.

The chelipeds are long, slender, and altogether lacking in armature, with the exception of a tubercle on the prehensile edge of the movable finger; the opposing finger has a sulcus into which the tubercle nicely fits.

The dactyls of the ambulatory feet are short and blunt; a fringe of short sharp spines render them prehensile in no small degree. The carapace and legs are set with long fine hair.

The type and only specimen is a female, with eggs, dredged by the Albatross at station 3715, in 68-65 fathoms, off Honshu Island, Japan.

Type.-Cat. No. 26166, U.S.N.M.

UROPTYCHUS SPINIGER, new species.

The rostrum is slender and sharp pointed, concave on the upper surface of the basal half. The antero-lateral

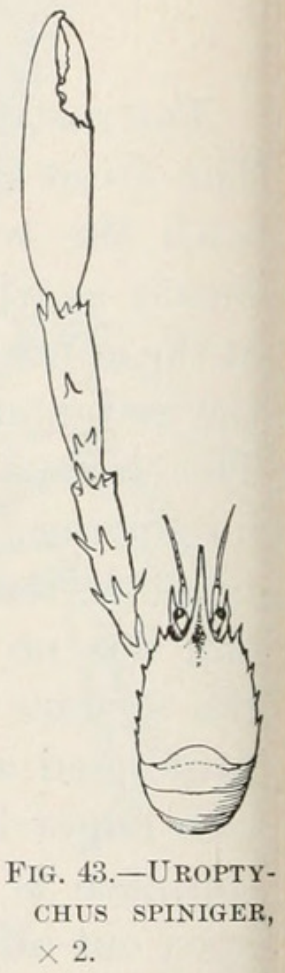
angles of the carapace are marked by large and very sharp spines. The lateral margins are armed with spines of uneven size, the one behind the antero-lateral is small, followed by a large one, which in turn is followed by two much smaller ones.

The meral and carpal joints of the maxillipeds are each armed on the distal upper angle with a single spine. The coxa and ischium of the chelipeds are each armed with a single spine; the merus with six very stout spines, three in a transverse row on the proximal portion, two near the middle, and one on the distal margin; there are three or four on the surface of the carpus and four short conical spines on the border next the palm. The merus of the ambulatory legs has two spines on the upper border. 
Length of carapace, $3.7 \mathrm{~mm}$; breadth, $4 \mathrm{~mm}$.; length of rostrum, $3 \mathrm{~mm}$. ; length of chelipeds, $18 \mathrm{~mm}$.

Locality.-Albatross station 2152, in 387 fathoms, off Habana. Type.-Cat. No. 7795, U.S.N.M.

Genus PTYCHOGASTER A. Milne-Edwards.

PTYCHOGASTER DEFENSA, new species.

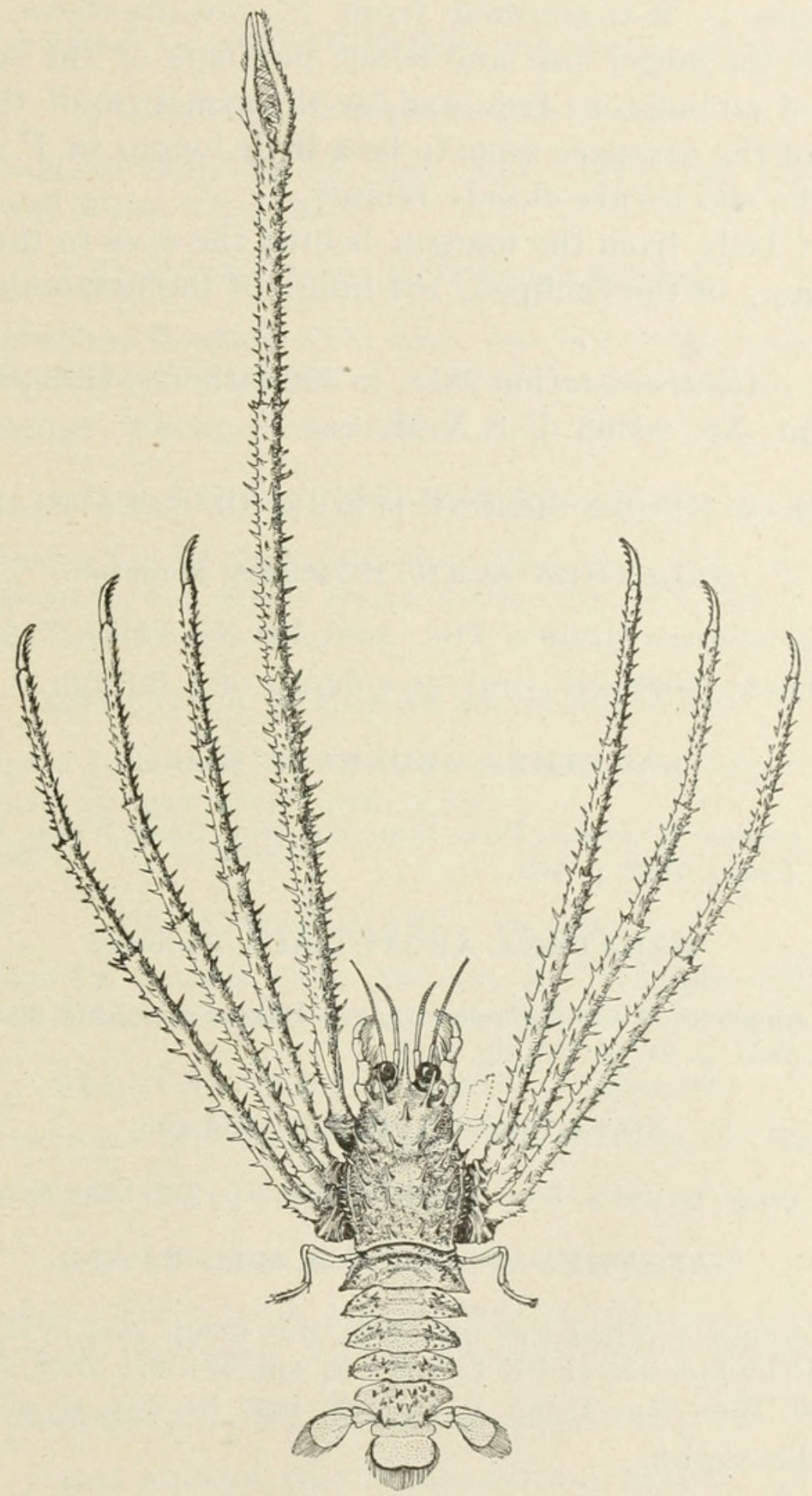

Fig. 44.-PTychogaster DeFENSA, $\times 1$.

The rostrum is slender and styliform, about twice as long as the eyes. The gastric area is armed with seven slender spines similar to the rostrum in appearance, but somewhat shorter; one is placed in the center of the area and the others at equal intervals from it, forming a Proc. N. M. vol. xxvi-02-21 
circle; four spines on the cardiac area form a square; there are six paired spines on the branchial areas and one on the hepatic.

The first and second segments of the abdomen are each armed with a row of large spines; the third, fourth, and fifth segments have a large paired spine on the side with a smaller spine close behind it; the sixth segment has a group of about twelve spines. The spines of the legs are long, slender, and curved, numerous but not crowded.

This species is distinguished from $P$. investigatoris Alcock and Anderson by the larger size and lesser numbers of the spines on the chelipeds and ambulatory feet, and by the armature of the abdomen. The spines of the carapace seem to be a little longer in $P$. defensa, but in general the species are closely related.

Length of body from the margin behind the eyes to the end of the telson, $33 \mathrm{~mm}$; of the cheliped, $104 \mathrm{~mm}$; of the first ambulatory leg, $60 \mathrm{~mm}$.

Locality. - Albatross station 2818, in 392 fathoms, Galapagos Islands. Type.-Cat. No. 20563, U.S.N.M.

\section{LIST OF KNOWN MARINE SPECIES OF GALATHEID E.}

\section{GALATHEA ACANTHOMERA Stimpson.}

Galathea acanthomera Stimpson, Proc. Acad. Nat. Sci. Phila., X, 1858, p. 252. Bonin Islands, between coral, at a depth of 1 fathom.

\section{GALATHEA ACULEATA Haswell.}

Galathea aculeata Hasweld, Proc. Linn. Soc. New South Wales, VI, p. 761; Cat. Aust. Crust., 1882, p. 162.

\section{GALATHEA AEGYPTIACA Paulson.}

Galathea aegyptiaca PAulson, Izsledovaniya Rakoobraznikh Krasnago Morya, I, Kief, 1875, p. 94, pl. xII, fig. 1-1b.

\section{GALATHEA AFFINIS Ortmann.}

Galathea affinis Ortmann, Zool. Jahrb. System., p. 252, 1892, pl. II, fig. 9.

\section{GALATHEA AGASSIZI A. Milne-Edwards.}

Galuthea agassizi A. Mrlne-Edwards, Bull. Mus. Comp. Zool., VIII, 1880, p. 47.-

A. Milne-Edwards and E. L. Bouvier, Ann. Sci. Nat. Zool., (7), XVI, 1894,

p. 252; Mem. Mus. Comp. Zool., XIX, 1897, No. 2, p. 17, pl. I, figs. 6-15.

West India region.

\section{GALATHEA ANDREWSI Kinahan.}

Galathea andrewsi Kinahan, Proc. Nat. Hist. Soc., Dublin, II, p. 58, pl. xvi, fig. 8 .

Galathea intermedia Bonnier, Bull. Sci. France et Belg., (3), XIX, 1888, p. 130.

Specimens in the Museum can be distinguished from $G$. intermedia (see key, p. 247); the review is, however, incomplete 


\section{GALATHEA AUSTRALIENSIS Stimpson.}

Galathea australiensis Stmpson, Proc. Acad. Nat. Sci. Phila., X, 1858, p. 251.

Galathea australiensis Haswell, Cat. Aust. Crust., 1882, p. 161.

GALATHEA BREVIMANA Paulson.

Galathea brevimana Paulson, Izsledovaniya Rakoobraznikh Krasnago Morya, I, Kief, 1875 , p. 95.

GALATHEA CALIFORNIENSIS, new species, see p. 247.

GALATHEA CORALLICOLA Haswell.

Galathea corallicola Hasweld, Cat. Aust. Crust., 1882, p. 162; Proc. Linn. Soc, New South Wales, VI, p. 761.

\section{GALATHEA DEFLEXIFRONS Haswell.}

Galathea deflexifrons Hasweld, Proc. Linn. Soc. New South Wales, VI, p. 761; Cat, Aust. Crust., 1882, p. 163.

Albany Passage, among Comatulids.

\section{GALATHEA DISPERSA Spence Bate.}

Galathea dispersa Spence Bate, Jour. Proc. Linn. Soc. Lond., Zool., III, 1859, p. 3.-Bonnier, Bull. Scient. France et Belg., (3), XIX, 1888, p. 154, pl. XIII, figs. 1-3. (See for synonymy.)

GALATHEA ELEGANS Adams and White.

Galathea elegans Adams and White, Zool. Samarang, Crustacea, pl. xiI, fig. 7.Haswell, Cat. Aust. Crust., 1882, p. 163.

Holborn Island, 20 fathoms.

\section{GALATHEA GIARDI Th. Barrois.}

Galathea giardi Th. Barrois, Crust. Podopht. de Concarneau, 1882, p. 22; Cat. des Crust. Marins Recueillis aux Açores, 1888, p. 21, pl. II, fig. 1.

\section{GALATHEA GRANDIROSTRIS Stimpson.}

Galathea grandirostris Strupson, Proc. Acad. Nat. Sci. Phila., X, 1858, p. 252. Japan, Kagosima Bay, in 5 fathoms.

\section{GALATHEA INCONSPICUA Henderson.}

Galathea inconspicua Henderson, Ann. and Mag. Nat. Hist., (5), X VI, 1885, p. 408; Voyage of the Challenger, XXVII, Anomura, 1888, p. 122, pl. XII.

GALATHEA INTEGRA, new species, see p. 248 .

GALATHEA INTEGRIROSTRIS Dana.

Galathea integrirostris DANA, U. S. Explor. Exped., Crust., 1858, p. 482, pl. xxx, fig. 12 .

Dredged at Tahaina, Sandwich Islands.

a Galathea integra differs in that the rostrum is very much more acute in integra and the merus of the maxillipeds is short and broad, its inner margin armed with a large spine. 


\section{GALATHEA INTERMEDIA Lilljeborg.}

Galathea intermedia Linljebong, Öfvers. Vet. Akad. Forhandl., 1851, p. 21.

Galathea parroceli GounRet, Décapod. Macrou. nouv. du Golfe de Marseilles, Compt. Rend. Acad., CV, 1887, p. 1034.

Galathea intermedia Bonnier, Bull. Scient. France et Belg., (3), XIX, 1888, p. 130.

Bonnier makes $G$. andrewsi a synonym of this species. Of the correctness of this I do not feel at all sure.

\section{GALATHEA LABIDOLEPTA Stimpson.}

Galathea labidolepta Strupson, Proc. Acad. Nat. Sci. Phila., X, 1858, p. 251.

Cape of Good Hope.

\section{GALATHEA LATIROSTRIS Dana.}

Galathea latirostris Dana, U. S. Explor. Exped., Crust., 1858, p. 480, pl. xxx, fig. 8. Fiji Islands. Among corals and in cavities of the coral rock. Nearly colorless.

GALATHEA LONGIMANA Paulson.

Galathea longimana PAulson, Izsledovaniya Rakoobraznikh Krasnago Morya, I, Kief, 1875, p. 94, pl. xıI, fig. 2-2a.

\section{GALATHEA LONGIROSTRIS Dana.}

Galathea longirostris DANA, U. S. Explor. Exped., Crust., p. 482, pl. xxx, fig. 11.

Fiji Islands. Brought up on a comatula from a depth of 10 fathoms.

\section{GALATHEA MACHADOI Th. Barrois.}

Galathea machadoi BARrois, Cat. des Crust. Marins Recueillis aux Açores, 1888, p. 22, pl. in, fig. 2-10.-A. Milne-Edwards and E. L. Bouvier, Ann. Ces Sci. Nat., (7), XVI, 1894, p. 252.

\section{GALATHEA MAGNIFICA Haswell.}

Galathea magnifica Hasweld, Proc. Linn. Soc. New South Wales, VI, p. 761; Cat. Aust. Crust., p. 162.

\section{GALATHEA NEXA Embleton.}

Galathea nexa Embleton, Proc. Berwick. Nat. Field Club.-Bonnier, Bull. Scient. France et Belg., (3), XIX, p. 149, pl. xII, figs. 6, 8. (See for synonymy.)

\section{GALATHEA ORIENTALIS Stimpson.}

Galathea orientalis Strmpson, Proc. Acad. Nat. Sci. Phila., X, 1858, p. 252.Ortmann, Zool. Jahrb. Syst., 1892, p. 252, pl. iI, fig. 10.

In the Strait of Lyimoon near Hongkong, in 25 fathoms. 
GALATHEA PAUCI-LINEATA, new species, see p. 249.

GALATHEA PUBESCENS Stimpson.

Galathea pubescens Stimpson, Proc. Acad. Nat. Sci. Phila., X, 1858, p. 252.

Japan, in the port of Hakodadi, and at the island of Ousima, in 25 to 35 fathoms.

\section{GALATHEA PUSILLA Henderson.}

Galathea pusilla Henderson, Ann. and Mag. Nat. Hist., (5), XVI, 1885, p. 407; Voyage of the Challenger, XXVII, 1888, p. 121, pl. XII, fig. 1.

Off Twofold Bay, Australia, in 150 fathoms.

\section{GALATHEA ROSTRATA A. Milne-Edwards.}

Galathea rostrata A. Milne-Edwards, Bull. Mus. Comp. Zool., VIII, 1880, p. 47.A. Milne-Edwards and E. L. Bouvier, Ann. des Sei. Nat., (7), XVI, 1894, p. 252; Mem. Mus. Comp. Zool., XIX, 1897, No. 2, p. 14, pl. I, figs. 1-5.

West India region.

GALATHEA, RUFIPES Edwards and Bouvier.

Gclathea rufipes A. Milne-Edwands and E. L. Bouvier, Ann. des Sci. Nat. Zool., (7), XVI, 1894, p. 252; Exped. Scient. du Travailleur et du Talisman, Brachy. et Anom., 1890, p. 280, pl. xxIX, figs. 4-8.

Cape Verde Islands.

\section{GALATHEA SPINOSOROSTRIS Dana.}

Galathea spinosorostris Dana, U. S. Explor. Exped. Crust., 1858, p. 480, pl. xxx, fig. 9a.

Sandwich Islands.

\section{GALATHEA SQUAMIFERA Leach.}

Galathea squamifera LeAch, Edin. Encycl., VII, p. 398.

Galathea fabricii Leach, Encycl. Brit. Supp., pl. xxI.

Galuthea squamifera LeAcH, Malacostraca Podophthalmata Britaniæ, 1815, pl. xxvin A., fig. 1.-Bonnier, Bull. Scient. France et Belg., (3), XIX, 1888, p. 143, pl. xII, figs.1-5. (For synonymy see this.)

Northern Europe.

\section{GALATHEA STRIGOSA Linnæus.}

Cancer strigosus Linneus Syst. Nat., 12th ed., 1766, p. 1052, No. 69.

Astacus strigosus Pennant, Brit. Zool., 1777, pl. xiv, fig. 26.

Galathea strigosa FABricius, Ent. Syst. Suppl., 1798, p. 414.-Bonnier, Bull. Scient. France et Belg., (3), XIX, 1888, p. 160, pl. xxIII, figs. 4-6 (synonymy).

Northern Europe.

GALATHEA SUBSQUAMATA Stimpson.

Galathea subsquamata Strmpson, Proc. Acad. Nat. Sci. Phila., X, 1858, p. 252. Island of Ousima. 


\title{
GALATHEA VITIENSIS Dana.
}

Galathea vitiensis DANA, U. S. Explor. Exped. Crust., 1858, p. 481, pl. xxx, fig. 10a. Fijis, about corals. Length, one-fourth of an inch, nearly colorless.

\author{
GALACANTHA.
}

\section{GALACANTHA CAMELUS Ortmann.}

Galacantha camelus Ortmann, Zool. Jahrb. Syst., p. 257, 1892, pl. II, fig. 14.

\section{GALACANTHA DIOMEDEÆ Faxon.}

Galacantha diomeder FAxon, Bull. Mus. Comp. Zool., 1893, p. 180; Mem. Mus. Comp. Zool., XVIII, 1895, p. 79, pl. xxv, fix. 1.

GALACANTHA FAXONI, new name.

Galacantha rostrata FAxon, Bull. Mus. Comp. Zool., VIII, 1880, p. 52; Mem. Nius. Comp. Zool., XVIII, 1895, p. 78, pl. B, figs. 1, 1a.

The differences which in my opinion separate this species from C. rostrata of the West Indian region were clearly seen by Mr. Faxon. He had before him seven specimens from stations 3362,3400 , and 3414. His conclusions were that "The Albatross specimens differ constantly from the typical West Indian form in the following particulars: The spines at the antero-lateral angles of the carapace are more divergent, the anterior spine being more nearly parallel with the axis of the body; the posterior spine is relatively longer; the abdomen is smoother toward the central part of the segments; the dorsal spine of the fourth abdominal segment is smaller. In other regards there is considerable variation among different individuals."

\section{GALACANTHA INVESTIGATORIS Alcock and Anderson.}

Galacantha investigatoris Alcock and Anderson, Jour. Asiat. Soc. Bengal, LXIII, 1894, p. 173.-A - Acock, Illus. Zool. Investigator, Crustacea, 1895, pl. xII, fig. 4. Galacantha rostrata var. investigator is Aцсоск, Cat. Indian Deep-Sea Crust. Indian Museum, 1901, p. 276.

Arabian Sea, off the Island of Minicoy, 1,200 fathoms.

\section{GALACANTHA RostratA A. Milne-Edwards.}

Galacantha rostrata A. Milne-Edwards, Bull. Mus. Comp. Zool., 1880, VIII, p. 52.-S. I. Sмiтh, Bull. Mus. Comp. Zool., X, 1882, p. 21, pl. Ix, fig. 2; Ann. Report U. S. Fish Com. for 1882, 1884, p. 355.-A. Milne-Edwards and Bouvier, Ann. Sci. Nat. Zool., (7), XVI, 1894, p. 271.-Faxon, Mem. Mus. Comp. Zool., XVIII, 1895, p. 78, pl. в, figs. 1, 1a; Mem. Mus. Comp. Zool., XIX, No. 2, 1897, p. 60, pl. Iv, figs. 21-24.

Galacantha talismani H. Filhol, La Vie au Fond des Mers, 1884, pl. III.-Ed. Perier, Les Explorations Sous-Marines, 1885, fig. 8, p. 341.-Henderson, Challenger Report, XXVII, 1888, Anomura, p. 167, pl. xx, fig. 1.

Galacantha bellis Hendenson, Challenger Report, XXVII, 1888, Anomura, p. 167, pl. xIx, fig. 6.

Galacantha areolata Wood-Mason, Ann. Mag. Nat. Hist., 1891, p. 200. 
Munidopsis rostrata S. I. Sмiтh, Proc. U. S. National Museum, VII, 1885, p. 493;

Report of the U. S. Fish Com. for 1885, 1886, p. 45, pl. vi, fig. 1.

Galacantha rostrata A Lcock, Cat. Indian Deep-Sea Crust., 1901, p. 275.

Western Europe and West Indies.

GALACANTHA SPINOSA A. Milne-Edwards.

Galacantha spinosa A. Milne-Edwards, Bull. Mus. Comp. Zool., VIII, 1880, p. 53.-A. Milne-Edwards and E. L. Bouvier, Ann. des Sci. Nat. Zool., (7), X VI, 1894, p. 270; Mem. Mus. Comp. Zool., XIX, 1897, p. 56, pl. rv, figs. $15-20$.

\section{GALACANTHA TRACHYNOTUS Anderson.}

Galacantha trachynotus Anderson, Jour. Asiat. Soc. Bengal, LXV, 1896, p. 100.A lcock, Illus. Zool. Investigator, Crustacea, 1896, pl. xxv, fig. 3.

Galacantha spinosa var. trachynotus A цсоск, Cat. Indian Deep-Sea Crust., Indian Museum, 1901, p. 277.

Arabian Sea, 912-931, and 947 fathoms.

\section{PLEURONCODES Stimpson.}

\section{PLEURONCODES MONODON (M. Edwards.)?}

?Galathea monodon M. Edwards, Hist. Nat. Crust., II, 1837, p. 276.

?Pleuroncodes monodon Stimpson, Ann. Lyc. Nat. N. Y., VII, 1860, p. 245.FAxon, Bull. Mus. Comp. Zool., XXIV, 1893, p. 176; Mem. Mus. Comp. Zool., XVIII, 1895 , p. 72 , pl. Xv, fig. 3 .

\section{PLEURONCODES PLANIPES Stimpson.}

Pleuroncodes planipes Strmpson, Ann. Lyc. Nat. Hist. N. Y., VII, April, 1860, p. 245.

CERVIMUNIDA, new genus, see p. 249.

CERVIMUNIDA PRINCEPS, new species, see p. 249.

MUNIDA Leach.

Munida Leach, Dict. Sci. Nat., XVIII, 1820, p. 52.

\section{MUNIDA AFFINIS A. Milne-Edwards.}

Munida affinis A. Mrlne-Edwards, Bull. Mus. Comp. Zool., VIII, 1880, p. 48.A. Milne-Edwards and Bouvier, Ann. des Sci. Nat. Zool., (7), XVI, 1894, p. 257; Mem. Mus. Comp. Zool., XIX, 1897, No. 2, p. 53, pl. III, fig. 14.

Munida affinis Benedict, The Anomuran Collections made by the Fish Hawk

Expedition to Porto Rico, U. S. Fish Commission Bull. for 1900, p. 147.

This species was taken off Habana at stations 2169 in 78 fathoms, 2321 in 230 fathoms, 2329 in 118 fathoms, 2346 in 200 fathoms. Off the south coast of Cuba at stations 2129 in 274 fathoms, 2130 in 175 fathoms, 2131 in 202 fathoms, 2133 in 290 fathoms, 2135 in 250 fathoms. Off the west end of Cuba at station 2350 in 250 fathoms. One lot is labeled station 2138 in 23 fathoms off the east end of 
Jamaica. It is possible that some mistake has been made in this station number, as this species did not occur in other shallow-water dredging.

\section{MUNIDA ANDAMANICA Alcock.}

Munida militaris var. andamanica Аlсock, Ann. and Mag. Nat. Hist., (6), XIII, 1894, p. 321; Illus. Zool. of Investigator Crust., 1895, pl. xIII, fig. 2; Desc. Cat. Indian Deepsea Crust., Indian Museum, p. 242.

"From the Andaman Sea," "173-419 fathoms, and from the Arabian Sea, in the neighborhood of the Laccadives and Maldives, 210-360 fathoms."

MUNIDA ANGULATA, new species, see p. 252.

MUNIDA AUSTRALIENSIS Henderson.

Munida subrugosa var. australiensis Hendenson, Challenger Report, XXVII, 1888, p. 125 , pl. xin, fig. 3.

The characters given by $\mathrm{Mr}$. Henderson are sufficient for specific rank in the absence of intergrading forms.

Challenger station 162 off East Moncoeur Island, Bass Strait; depth 38 to 40 fathoms. Several specimens, the majority of which are females; the body of the largest measures only $25 \mathrm{~mm}$. in length.

\section{MUNIDA BAMFFICA (Pennant).}

Astacus bamfficus Pennant, Brit. Zool., IV, 1777, pl. xIII, fig. 25. Galathea rugosa Fabricius, Ent. Syst., II, 1798, p. 472; Suppl., p. 415. Galathea longipeda Laмaвck, Syst. des Anim. sans vert., 1808, p. 128. Munida rondeletii Gondon, The Zoologist, X, 1852, p. 3678, London. Munida bamffia Norman, Report on Dredgings, Shetland, 1868, p. 265. Munida tenuimana G. O. SARs, Vidensk. Selsk. Forhand. Christ., 1871, p. 257. Munida bamffia Bonnier, Bull. Sci. France et Belg., (3), XIX, 1888, p. 164, pl. xiII, figs. 7 and 8 .

Munida bamffica A. Milne-Edwards and E. L. Bouvier, Crustaces Decapodes provenant des campagnes du yacht l'Hirondelle (1886, 1887, 1888), Pt. 1, Brachyures et Anomoures, Res. Camp. Scient., Albert, I, Pt. 7, 1894, p. 83, pl. vir, fig. 1-7; Pt. 12, XIII, 1899, p. 75, pl. iv, figs. 6-16, Monaco.

The ten figures in the last work referred to show the variations of this species. From this work and that of J. Bonnier full synonymy and reference can be made out.

European waters.

\section{MUNIDA CARIBAA Stimpson.}

Munida caribra Stmmpson, Ann. Lyc. Nat. Hist. New York, VII, 1860, p. 244.

Dr. Faxon says of this: "The specimens doubtfully referred to, Munida caribxa Stimpson, by Prof. S. I. Smith are Munida iris of Milne-Edwards. Stimpson's Munida caribxa is absolutely indeterminable from his brief notice of it, and the types were burned in the great Chicago fire. The name caribæa should then be dropped and Milne-Edwards's iris and irrasa should be retained." a 
MUNIDA COMORINA Alcock and Anderson.

Munida comorina Alcock and Anderson, Ann. and Mag. Nat. Hist., (7), III, 1899, p. 18; Illus. Zool. Invest. Crust., pl. xLII, fig. 3.

\section{MUNIDA CONSTRICTA A. Milne-Edwards.}

Munida constricta A. Milne-Edwards, Bull. Mus. Comp. Zool., VIII, 1880, p. 52.-A. Milne-Edwards and Bouvier, Ann. Sci. Nat. Zool., (7), XVI, 1894, p. 256; Mem. Mus. Comp. Zool., XIX, 1897, No. 2, p. 40, pl. III, fig. 5.

West India region.

MUNIDA CURVATURA, new species, see p. 253.

MUNIDA CURVIMANA Edwards and Bouvier.

Munida curvimana A. Milne-Edwards and E. L. Bouvier, Ann. des Sci. Nat. Zool., 1894, (7), XVI, p. 256; Exped. Scient. du Travailleur et du Talisman, Brachyures et Anomoures, 1900, p. 287, pl. xxIx, fig. 12-16.

MUNIDA CURVIPES, new species, see p. 254.

MUNIDA CURVIROSTRIS Henderson.

Munida curvirostris Hendenson, Ann. and Mag. Nat. Hist., (5), XVI, 1885, p. 412. Munida militaris var. curvirostris Hendenson, Challenger Report, XXVII, 1888, p. 139 , pl. III, fig. 7 .

Mabitat.-Station 200, off Sibago, Philippines; depth, 250 fathoms; bottom, green mud. An adult male measuring $25 \mathrm{~mm}$. in length (not including the rostrum). Station 210, off Zebu, Philippines; depth, 375 fathoms; bottom, blue mud. An adult female measuring $20 \mathrm{~mm}$. in length.

MUNIDA DEBILIS, new species, see p. 256.

MUNIDA DECORA, new species, see p. 257.

MUNIDA EDWARDSII Miers.

Munida edwardsii Miens, Alert Crustacea, 1884, p. 560, pl. LI, fig. A.

MUNIDA EVERMANNI Benedict.

Munida evermanni Benedict, Anomuran Collections made by the Fish Hawk Expedition to Porto Rico, 1901, p. 146, pl. v, fig 4.

MUNIDA FLINTI, new species, see p. 258.

European seas.

MUNIDA FORCEPS A. Milne-Edwards.

Munida forceps A. Mrlne-Edwards, Bull. Mus. Comp. Zool., VIII, 1880, p. 49.Perrier, Les Explorations Sous Marines, fig. 109, p. 220.-A. MilneEdwards and Bouvier, Ann. des Sci. Nat. Zool., (7), XVI, 1894, p. 256; Mem. Mus. Comp. Zool., XIX, 1897, No. 2, p. 28, pl. II, fig. 8.

West Indian region. 


\section{MUNIDA GRACILIPES Faxon.}

Munida gracilipes Faxon, Bull. Mus. Comp. Zool., XXIV, 1893, p. 179; Mem. Mus. Comp. Zool., XVIII, 1895, p. 77, pl. xvi, figs. 2-2b.

Gulf of Panama.

\section{MUNIDA GRACILIS Henderson.}

Munida gracilis Henderson, Ann. and Mag. Nat. Hist., (5), XVI, 1885, p. 412; Challenger Report, XXVII, 1888, Anomura, p. 143, pl. xIv, fig. 4.

Challenger station 166; depth, 275 fathoms, west of New Zealand. Two specimens.

\section{MUNIDA GRANULATA Henderson.}

Munida granulata Henderson, Ann. and Mag. Nat. Hist., (5), XVI, 1885, p. 409; Challenger Report, XXVII, 1888, Anomura, p. 133, pl. xIv, tig. 3.

Challenger station 173; depth, 315 fathoms, off Fiji Islands. Nine specimens.

Henderson says of this (page 134): "The second and third abdominal segments bear six spinules each, four of which are arranged on the anterior and two near the posterior margin; the third segment bears five spinules, a mesial one being present on the posterior margin, which is somewhat prominent." Did he not mean third armed segment rather than third segment, which he had just described? His figure shows spines on the second segment only.

\section{MUNIDA GREGARIA (Fabricius).}

Galathea gregaria FABricius, Ent. Syst., II, 1793, p. 473.

Grimothea gregaria LeAch, Dict. d. Sci. Nat., XVJII, 1820, p. 50.-Dana, U. S. Expl. Expd. Crust., XIII, 1852, Crust., Pt. 1, p. 483, pl. xxxI, fig. 1.

Grimothea novæ zelandix Frlhol, Passage de Venus, Mission de l'Ile Campbell, 1874, p. 426. (Institute de France.)

Munida gregaria Mrens, Proc. Zool. Soc. London, 1881, p. 73.

Munida subrugosa Henderson, Challenger Report, XXVII, 1888, Anomura, p. 124. Munida gregaria A. Minne-Edwards, Mission Scient. du Cap Horn, Crust., 1891, p. F. 32 , pl. II, fig. 1 .

Guérin's figure of "Grimotea gregaria" a shows eyestalks as long as those of the New Zealand specimen, but it seems to have little else in common. A. Milne-Edwards has given the best account of the differences separating this species from $M$. subrugosa and has shown in a good figure the differences observed between its own adult and immature forms. In my opinion the question of the identity of the Cape Horn species with that from New Zealand remains yet an open question, which can only be settled by comparison of a large series of specimens from both localities.

The young of Munida gregaria differ more from the adult than is the case with the young of any other species represented in the col- 
lection. In three specimens from New Zealand, the rostrum is only a little longer than the eyes and the supraocular spines are very short and much more divergent than in the adults. The eyestalks are proportionately longer than in any species of the genus in the collection. In alcohol the eyes are transverse in direction and extend beyond the line of the sides by about one-half of the diameter of the cornea. The antero-lateral angles are rounded in the young, in sharp contrast with the angles of the adult, which are armed with a large double spine, giving it an angular appearance. The carapace in the young has the two spines on the gastric area behind the supra-ocular spines and a very small paired spine in line with these. The posterior margin of the cervical suture is

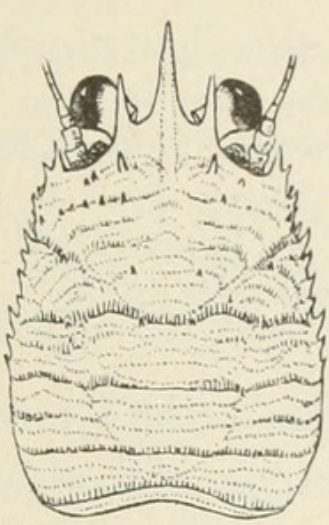

FIG. 45.-MUNIDA GREGARIA, $\times 1$.

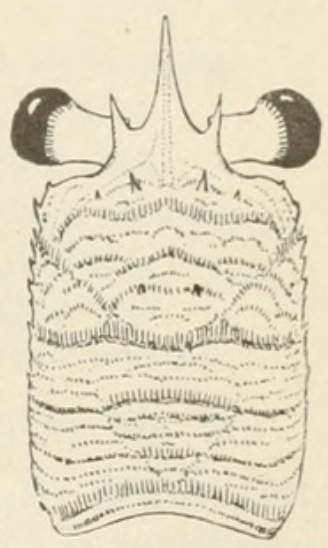

Fig. 46.-MUNIDA GREGARIA, YOUNG, $\times 2 \frac{1}{2}$. armed with four spines. In addition to these spines in the adult there are about eight spines on the first ciliated line behind the gastric pair and another pair posterior to these. The armature of the abdomen is the same in both forms; the maxillipeds are similar, but longer in the young.

The three specimens from New Zealand range about $45 \mathrm{~mm}$. in length while numerous specimens of the adult from the Straits of Magellan range from 110 to $115 \mathrm{~mm}$. Younger specimens may vary much more from the adult form.

\section{MUNIDA HASWELLI Henderson.}

Munida haswelli Henderson, Ann. and Mag. Nat. Hist., (5), XVI, 1885, p. 411; Challenger Report, XXVII, Anomura, p. 139, pl. III, fig. 5.

Challenger station 163A, depth 150 fathoms, off Twofold Bay, Australia. One male and three young.

MUNIDA HETERACANTHA Ortmann.

Munida heteracantha Ortmans, Zool. Jahrb., VI, 1892, p. 255, pl. II, fig. 12. Japan.

MUNIDA HISPIDA, new species, see p. 259.

MUNIDA HONSHUENSIS, new species, see p. 261.

MUNIDA INCERTA Henderson.

Munida incerta Henderson, Challenger Report, XXVII, 1888, p. 130, pl. xiII, fig. 4 .

Challenger station 200, depth 250 fathoms, off Sibago Island, Philippines. One imperfect specimen. 


\section{MUNIDA INORNATA Henderson.}

Munida inornata Henderson, Ann. and Mag. Nat. Hist., (5), XVI, 1885, p. 411; Challenger Report, XXVII, Anomura, 1885, p. 140, pl. xvi, fig. 6.

Challenger station 219, depth 150 fathoms, north of New Guinea. One specimen.

\section{MUNIDA IRIS A. Milne-Edwards.}

Municia iris A. Mrlne-Edwands, Bull. Mus. Comp. Zool., VIII, 1880, p. 49.A. Milne-Edwards and Bouvier, Ann. Sci. Nat., Zool., (7), XVI, 1894, p. 256; Mem. Mus. Comp. Zool., XIX, 1897, No. 2, p. 21, pl. II, figs. 2-7.

Munida caribra? S. I. Sмптн, Proc. U. S. Nat. Mus., III, 1881, p. 428; VI, 1883, p. 40, pl. II, fig. 11; Report U. S. Fish Commissioner for 1882, 1884, p. 255, and Report for 1885,1886, p. 39.

Munida, species indt. S. I. Sмrтtн, Bull. Mus. Comp. Zool., X, 1882, p. 22, pl. x.

Off the eastern coast of the United States. Albatross station 2420 in a depth of 47 fathoms, and at numerous other stations. A very abundant species.

\section{MUNIDA IRRASA A. Milne-Edwards.}

Munida irrasa A. Minne-Edwards, Bull. Mus. Comp. Zool., VIII, 1880, p. 49. Munida caribra A. Minne-Edwards, Bull. Mus. Comp. Zool., VIII, 1880, p. 49.A. Milne-Edwards and Bouvier, Ann. Sci. Nat., Zool., (7), XVI, 1894, p. 256; Mem. Mus. Comp. Zool., XIX, 1897, No. 2, p. 25, pl. I, figs. 16-20; pl. II, fig. 1.

Southeastern coast of the United States and West India region.

\section{MUNIDA JAPONICA Stimpson.}

Munida japonica Strmpson, Proc. Acad. Nat. Sci. Phil., X, 1858, p. 252.-OrTmann, Crustacea of the Semon Collection, 1894, p. 24; Jena.-Miers, Proc. Zool. Soc. Lond., 1879, p. 51.

In Kagoshima Bay, Japan, in 20 fathoms.

\section{MUNIDA LONGIPES A. Milne-Edwards.}

Munida longipes A. Mrnne-Edwards, Bull. Mus. Comp. Zool., VIII, 1880, p. 50.-

A. Milne-Edwards and Bouvier, Ann. Sci. Nat., Zool., (7), XVI, 1894, p. 257; Mem. Mus. Comp. Zool., XIX, 1897, No. 2, p. 44, pl. III, figs. 9-13.

West India region.

MUNIDA MEDIA, new species, see p. 262.

MUNIDA MEXICANA, new species, see p. 264 . MUNIDA MICROPHTHALMA A. Milne-Edwards.

Munida microphthalma A. Minne-Edwards, Bull. Mus. Comp. Zool., 1880, VIII, p. 51.-Henderson, Challenger Report, XXVII, 1888, Anomura, p. 127, pl. III, fig. 4 . 
Munida microphthalma (A. M. Edwards?) FAxon, Bull. Mus. Comp. Zool., XXIV, 1893, p. 179; Mem. Mus. Comp. Zool., XVIII, 1895, p. 78.-A. Milne-Edwards and Bouvier, Ann. Sci. Nat., Zool., (7), XVI, 1894, p. 256; Mem. Mus. Comp. Zool., XIX, 1897, No. 2, p. 32, pl. II, figs. 9-13.

West India region.

MUNIDA MICROPS Alcock.

Munida microps Alcock, Ann. and Mag. Nat. Hist., (6), XIII, 1894, p. 326; Illus. Zool. Investigator, Crust., 1895, pl. xIII, fig. 5; Desc. Cat. of Indian DeepSea Crust., Macrura and Anomalia, in the Indian Museum, 1901, p. 240.

\section{MUNIDA MICROPS var. LASIOCHELES Alcock.}

Munida microps var. lasiocheles ALсоск, Ann. and Mag. Nat. Hist., (6), XIII, p. 327; Illus. Zool. Investigator, Crust., 1895, pl. xıII, fig. 8; Desc. Cat. of Indian Deep-Sea Crust. in the Indian Museum, 1901, p. 241.

\section{MUNIDA MILES A. Milne-Edwards.}

Munida miles A. Mrune-Edwards, Bull. Mus. Comp. Zool., VIII, 1880, p. 51.Henderson, Challenger Report, XX VII, 1888, Anomura, p. 126.-A. MilneEdwards and Bouvier, Ann. Sci. Nat., Zool., (7), XVI, 1894, p. 256; Mem. Mus. Comp. Zool., XIX, 1897. No. 2, p. 35, pl. In, figs. 1-4.

West India region.

\section{MUNIDA MILITARIS Henderson.}

Munida militaris Henderson, Ann. and Mag. Nat. Hist., (5), XVI, 1885, p. 410; Challenger Report, XXVII, 1888, Anomura, p. 137, pl. yrr, figs. 2, 5.

Munida vitiensis Henderson, Ann. and Mag. Nat. Hist., (5), XVI, 1885, p. 410. Challenger station 173, depth 315 fathoms, off Matuku. Station 192, depth 140 fathoms, off Little Ki Island. Amboina, 100 fathoms.

\section{MUNIDA NORMANI Henderson.}

Munida normani Hendersox, Ann. and Mag. Nat. Hist., (5), XVI, 1885, p. 408; Challenger Report, XXVII, 1888, Anomura, p. 129, pl. xIII, fig 5.

Challenger station 173, off Matuku, Fiji Islands; depth, 315 fathoms.

MUNIDA NUDA, new species, see p. 265.

MUNIDA OBESA Faxon.

Mumda obesa FAxon, Bull. Mus. Comp. Zool., XXIV, 1893, p. 176; Mem. Mus. Comp. Zool., XVIII, 1895, p. 73, pl. xvi, figs. 1, 1a.

Gulf of Panama; station 3355 in 182 fathoms and station 3389 in 210 fathoms.

MUNIDA PERARMATA Edwards and Bouvier.

Munida perarmata A. Milne-Edwards and Bouvier, Ann. des Sci. Nat., Zool., (7), XVI, 1894, p. 257; Résult. des Camp. Scient. de l’Hirondelle (Supp.) et de la Princesse-Alice, Pt. 13, 1899, p. 81; Expéd. Scient. du Travailleur et du Talisman, Brachyures et Anomoures, 1900, p. 305, pl. xxx, fig. 1.

European waters. 
MUNIDA PERLATA, new species, see p. 266.

\section{MUNIDA PROPINQUA Faxon.}

Munida propinqua FAxon, Bull. Mus. Comp. Zool., XXIV, 1893, p. 178; Mem. Mus. Comp. Zool., XVIII, 1895, p. 76, pl. xviII, figs. 1, 1a.

Gulf of Panama and near the Galapagos Islands, 385 to 511 fathoms.

\section{MUNIDA PROXIMA Henderson.}

Munida proxima Henderson, Ann. and Mag. Nat. Hist., (5), X VI, 1885, p. 410; Challenger Report, XXVII, 1888, Anomura, p. 135, pl. XII, fig. 2.

Challenger station 219, north of New Guinea; depth 150 fathoms. Three adult specimens, one with ova.

MUNIDA PUSILLA, new species, see p. 268.

MUNIDA QUADRISPINA, new species, see p. 269.

MUNIDA REFULGENS Faxon.

Munida refulgens FAxon, Bull. Mus. Comp. Zool., XXIV, 1893, p. 177; Mem. Mus. Comp. Zool., XVIII, 1895, p. 75, pl. xviI.

Off Cocos Island, off coast of Ecuador, and near Tres Marias Islands; depth 42 to 112 fathoms. Sixty-seven specimens.

MUNIDA ROBUSTA A. Milne-Edwards.

Munida robusta A. Minne-Edwards, Bull. Mus. Comp. Zool., VIII, 1880, p. 48.A. Milne-Edwards and Bouvier, Ann. Sci. Nat., Zool., (7), XVI, 1894, p. 256; Mem. Mus. Comp. Zool., XIX, 1897, No. 2, p. 42, pl. in, figs. 6-8.

West India region.

\section{MUNIDA SANCTI-PAULI Henderson.}

Munida sancti-pauli Hendersox, Ann. and Mag. Nat. Hist., (5), XVI, 1885, p. 411; Challenger Report, XXVII, 1885, Anomura, p. 142, pl. III, fig. 6.

St. Paul's rocks; depth 10 to 60 fathoms. A female with ova and a young male.

\section{MUNIDA SCABRA Henderson.}

Munida scabra Henderson, Ann. and Mag. Nat. Hist., (5), XVI, 1885, p. 409; Challenger Report, XXVII, 1888, Anomura, p. 134, pl. xv, fig. 1.

Station 192, off Little Ki Island; depth 140 fathoms. Fifteen specimens.

MUNIDA SCULPTA, new species, see p. 270.

\section{MUNIDA SEMONI Ortmann.}

Munida semoni Ortmann, Crustacea of the Semon Collection, Jena, 1894, p. 24. 
MUNIDA SIMPLEX, new species, see p. 272.

\section{MUNIDA SPINICORDATA Henderson.}

Munida spinicordata Henderson, Ann. and Mag. Nat. Hist., (5), XVI, 1885, p. 413; Challenger Report, XXVII, 1888, Anomura, p. 146, pl. xv, fig. 3.

Challenger station 174 d, off Kandavu, Fiji; depth 210 fathoms. A male specimen.

\section{MUNIDA SPINIFRONS Henderson.}

Munida spinifrons Henderson, Ann. and Mag. Nat. Hist., (5), XVI, 1885, p. 412; Challenger Report, XXVII, 1888, Anomura, p. 144, pl. xv, fig. 1.

Challenger station 113a, anchorage off Fernando Noronha; depth 7 to 25 fathoms. A single specimen.

\section{MUNIDA SPINOSA Henderson.}

Munida spinosa Henderson, Ann. and Mag. Nat. Hist., (5), XVI, 1885, p. 408; Voyage of the Challenger, XXVII, 1888, Anomura, p. 128, pl. III, fig. 3.

Challenger station 320, off Rio de la Plata; depth 600 fathoms; bottom green sand. Several specimens, the majority of which are young.

\section{MUNIDA SPINULIFERA Miers.}

Munida spinulifera Mrens, Crustacea in Zool. H. M. S. Alert, 1884, p. 279, pl. xxxi, fig. A.-Henderson, Challenger Report, XXVII, 1888, p. 128.

Arafura Sea, 32 to 36 fathoms.

\section{MUNIDA SQUAMOSA Henderson.}

Munida squamosa Henderson, Ann. and Mag. Nat. Hist., (5), XVI, 1885, p. 409; Challenger Report, XXVII, 1888, p. 131, pl. xıI, fig. 1.

Challenger station 219, north of New Guinea; depth 150 fathoms.

\section{MUNIDA SQUAMOSA var. PROLIXA Alcock.}

Munida squamosa var. prolixa A Lcock, Ann. and Mag. Nat. Hist., (6), XIII, 1894, p. 322; Illus. Investigator Crust., 1895, pl. xırı, fig. 3; Des. Cat. of the Indian Deep-Sea Crust., 1901, p. 244.

\section{MUNIDA STIMPSONI A. Milne-Edwards.}

Munida stimpsoni A. Milne-Edwards, Bull. Mus. Comp. Zool., VIII, 1880, p. 47.-Henderson, Challenger Report, XXVII, 1888, p. 126, pl. xiv, fig. 1.-A. Milne-Edwards and Bouvier, Ann. Sci. Nat., Zool., (7), XVI, 1894, p. 257; Mem. Mus. Comp. Zool., XIX, 1897, No. 2, p. 48, pl. Iv, figs. 1-13.-BeneDICT, Anomuran collection made by the Fish Hawk Expedition to Porto Rico, 1901, p. 147, in U. S. Fish Commission Bulletin for 1900.

West India region. 


\section{MUNIDA SUBRUGOSA Dana.}

Munida subrugosa Dana, U. S. Exploring Expedition, XIII, 1852, Crust., p. 479, pl. xxx, fig. 7.-Miens, Zool. Erebus and Terror, Crust., 1874, p. 3, pl. III,

fig. 2; Cat. New Zealand Crust., 1876, p. 68.-Targioni Tozzetti, Crust. Magenta, 1877 , p. 234, pl. xIII, fig. 5 .

Galathea subrugosa Cunningham, Trans. Linn. Soc. Lond., (Zool.), XXVII, 1871, p. 495.

Munida subrugosa A. Mrune-Edwards, Mission Scient. du Cap Horn, Crust., 1891, p. F. 36 , pl. II, fig. 2 .

MUNIDA TENELLA, new species, see p. 274.

MUNIDA TRICARINATA Alcock.

Munida tricarinata Alcock, Ann. and Mag. Nat. Hist., (6), XIII, 1894, p. 324; Illustrations of the Investigator Crustacea, 1895, pl. xiI, fig. 1; Descriptive Catalogue of the Indian Deep-Sea Crustacea in the Indian Museum, 1901, p. 246.

Andaman Sea, 112 fathoms; Arabian Sea, off the N. Maldivc Atoll, 210 fathoms.

\section{MUNIDA TROPICALIS Edwards and Bouvier.}

Munida tropicalis A. Milne-Edwards and E. L. Bouvier, Bull. Mus. of Nat. Hist., III, 1897, p. 364; Expéd. Scient. du Travailleur et du Talisman, Brachyures et Anomoures, 1900 , p. 286, pl. xxix, figs. 9-11.

La Praya, 75 to 127 fathoms.

\section{MUNIDA TUBERCULATA Henderson.}

Munida tuberculata Henderson, Ann. and Mag. Nat. Hist., (5), XVI, 1895, p. 413; Challenger Report, XXVII, 1888, Anomura, p. 145, pl. xv, fig. 2.

Challenger station 173, 315 fathoms, off Matuku, Fiji Islands. Two specimens.

\section{MUNIDA VALIDA S. I. Smith.}

Munida valida S. I. Sмгтн, Proc. U. S. National Museum, VI, 1883, p. 42, pl. I.

Henderson in the Challenger Anomura, page 126, makes this species identical with $M$. miles. A. Milne-Edwards and E. L. Bouvier ${ }^{\iota}$ make it distinct. Several fine specimens in the Museum collection bear out the latter view.

\section{MUNIDA VIGILIARUM Alcock.}

Munida vigiliarum Alcock, Des. Cat. of the Indian Deep-Sea Crust. in the Indian Museum, 1901, p. 243. 
MUNIDOPSIS Whiteaves.

Munidopsis Whiteaves, Amer. Jour. Arts and Sci., 3d ser., VII, 1874, p. 212.

MUNIDOPSIS ABBREVIATA (A. Milne-Edwards).

Galathodes abbreviatus A. Milne-Edwards, Bull. Mus. Comp. Zool., VIII, 1880, p. 55 .

Munidopsis abbreviata A. Mrtne-Edwards and Bouvier, Ann. des Sci. Nat., Zool.,

(7), XVI, 1894, p. 275; Mem. Mus. Comp. Zool., XIX, 1897, No. 2, p. 91, pl. v, fig. 1.

Blake station 195, in 502 fathoms; Martinique. Stations 161 and 162 , in 583 and 734 fathoms; Guadeloupe.

\section{MUNIDOPSIS ABDOMINALIS (A. Milne-Edwards).}

Elasmonotus abdominalis A. Milne-Edwards, Bull. Mus. Comp. Zool., VIII, 1880, p. 61.-A. Milne-Edwards and Bouvier, Ann. des Sci. Nat., Zool., (7), XVI, 1894, p. 282; Mem. Mus. Comp. Zool., XIX, 1897, No. 2, p. 101, pl. viII, figs. $7-10$.

Blake station 291, in 200 fathoms, Barbados.

\section{MUNIDOPSIS ABYSSORUM (Edwards and Bouvier).}

Munidopsis abyssorum A. Milne-Edwards and E. L. Bouvier, Bull. Mus. Nat. Hist., III, 1897, p. 365; Expéd. Scient. du Travailleur et du Talisman, Brachyures et Anomoures, 1900, p. 319, pl. xxx, figs. 15-19.

European waters.

\section{MUNIDOPSIS ACULEATA Henderson.}

Munidopsis subsquamosa var. aculeata Henderson, Challenger Report, XXVII, 1888, Anomura, p. 153, pl. xvi, fig. 1.

Munidopsis subsquamosa aculeata FAxon, Mem. Mus. Comp. Zool., XVIII, 1895, p. 86 .

Challenger station 146, depth 1,375 fathoms, between Marion Island and the Crozets, a single specimen; also station 302 , depth 1,450 fathoms, west of Patagonia.

MUNIDOPSIS ACUMINATA, new species, see p. 277 .

MUNIDOPSIS ACUTA (A. Milne-Edwards).

Galathodes acutus A. Mrlne-Edwards, Comp. Rend. Acad. des Sci., 1881, p. 932. Munidopsis acuta A. Milne-Edwards and E. L. Bouvier, Ann. des Sci. Nat., Zool., (7), XVI, 1894, p. 230; Expéd. Scient. du Travailleur et du Talisman, 1900 , p. 312 , pl. $\mathrm{xxx}$, figs. $2-4$.

MUNIDOPSIS ACUTISPINA, new name.

Munidopsis aculeata A. Mrlne-Edwards and E. L. Bouvier, Ann. des Sci. Nat., Zool., (7), XVI,p. 275; Expéd. Scient. du Travailleur et du Talisman, Brachyures et Anomoures, 1900, p. 327, pl. xxxi, figs. 1-4.

A new name is necessary as aculeata was used by Henderson in the Challenger Anomura. See under aculeata, above.

Proc. N. M. vol. xxvi-02-22 


\section{MUNIDOPSIS AGASSIZII Faxon.}

Munidopsis agassizii FAxon, Bull. Mus. Comp. Zool., XXIV, 1893, p. 182; Mem. Mus. Comp. Zool., XVIII, 1895, p. 88, pl. XviII, figs. 4-4a.

Albatross station 3389, depth 210 fathoms, Gulf of Panama.

\section{MUNIDOPSIS ANTONII (A. Milne-Edwards).}

Galathodes antonii A. Mrlne-EDw Ands in Filhol, La Nature, XII, 1884, p. 231, fig. 2. Munidopsis antonii Henderson, Voyage of the Challenger, XXVII, 1888, Anomura, p. 151, pl. xvin, fig. 1.

Munidopsis antoni A. Milne-Edwards and E. L. Bouvier, Ann. des Sci. Nat. Zool., (7), XVI, 1894, p. 275; Expéd. Scient. du Travailleur et du Talisman, Brachyures et Anomoures, 1900, p. 321, pl. iv, fig. 2; pl. xxx, figs. 20-24.

\section{MUNIDOPSIS ARIES (A. Milne-Edwards).}

Orophorhynchus aries A. Minne-Edwands, Bull. Mus. Comp. Zool., VIII, 1880. p. 58.-A. Milne-Edwards and Bouvier, Ann. des Sci. Nat., Zool., (7), XVI, 1894, p. 287; Mem. Mus. Comp. Zool., XIX, 1897, No. 2, p. 111, pl. Ix, figs. $7-11$; pl. $x$, figs. $1,2$.

Blake station 236 , in 1,591 fathoms, west India region.

\section{MUNIDOPSIS ARIETINA Alcock and Anderson.}

Munidopsis arietina Alcock and Anderson, Jour. Asiatic Soc. Bengal, XLIII, Pt. 2, 1894, p. 171; Illus. Zool. Investigator, Crust., 1895, pl. xu, fig. 3.

Munidopsis (Orophorhynchus) arietina Alcock, Cat. Indian Deep-Sea Crust. in the Indian Museum, p. 269.

Bay of Bengal in 1,520 fathoms.

\section{MUNIDOPSIS ARMATA (A. Milne-Edwards).}

Elasmonotus armatus A. Milne-Edwards, Bull. Mus. Comp. Zool., VIII, 1880, p. 61.-Henderson, Challenger Report, XXVII, 1888, Anomura, p. 159, pl. xix, fig. 5.-A. Milne-Edwards and Bouvier, Ann. des Sci. Nat., Zool., (7), XVI, 1894, p. 282; Mem. Mus. Comp. Zool., XIX, 1897, No. 2, p. 104, pl. vIII, figs. 11-14.

Blake station 137, in 625 fathoms, West India region.

\section{MUNIDOPSIS ASPERA (Henderson).}

Elasmonotus asper Henderson, Ann. and Mag. Nat. Hist., (5), XVI, 1885, p. 416; Challenger Report, XXVII, 1888, Anomura, p. 163, pl. xıx, fig. 4.

Munidopsis aspera FAxox, Bull. Mus. Comp. Zool., XXIV, 1893, p. 188; Mem. Mus. Comp. Zool., XVIII, 1895, p. 96.

Challenger station 311, off Patagonia, in 425 fathoms. Upward of a dozen specimens. 
MUNIDOPSIS BAHAMENSIS, new species, see p. 278.

\section{MUNIDOPSIS BAIRDII (Smith).}

Galacantha bairdii Sмrтн, Report U. S. Fish Commission for 1882, 1884, p. 356. Munidopsis bairdii Sмrтh, Proc. U. S. National Museum. VII, 1884, p. 493; Ann. Report U. S. Fish Commission for 1885, 1886, p. 649, pl. v, fig. 2.-FAxoN, Mem. Mus. Comp. Zool., XVIII, 1895, p. 83.

Albatross station 2106, in 1,497 fathoms, off Virginia.

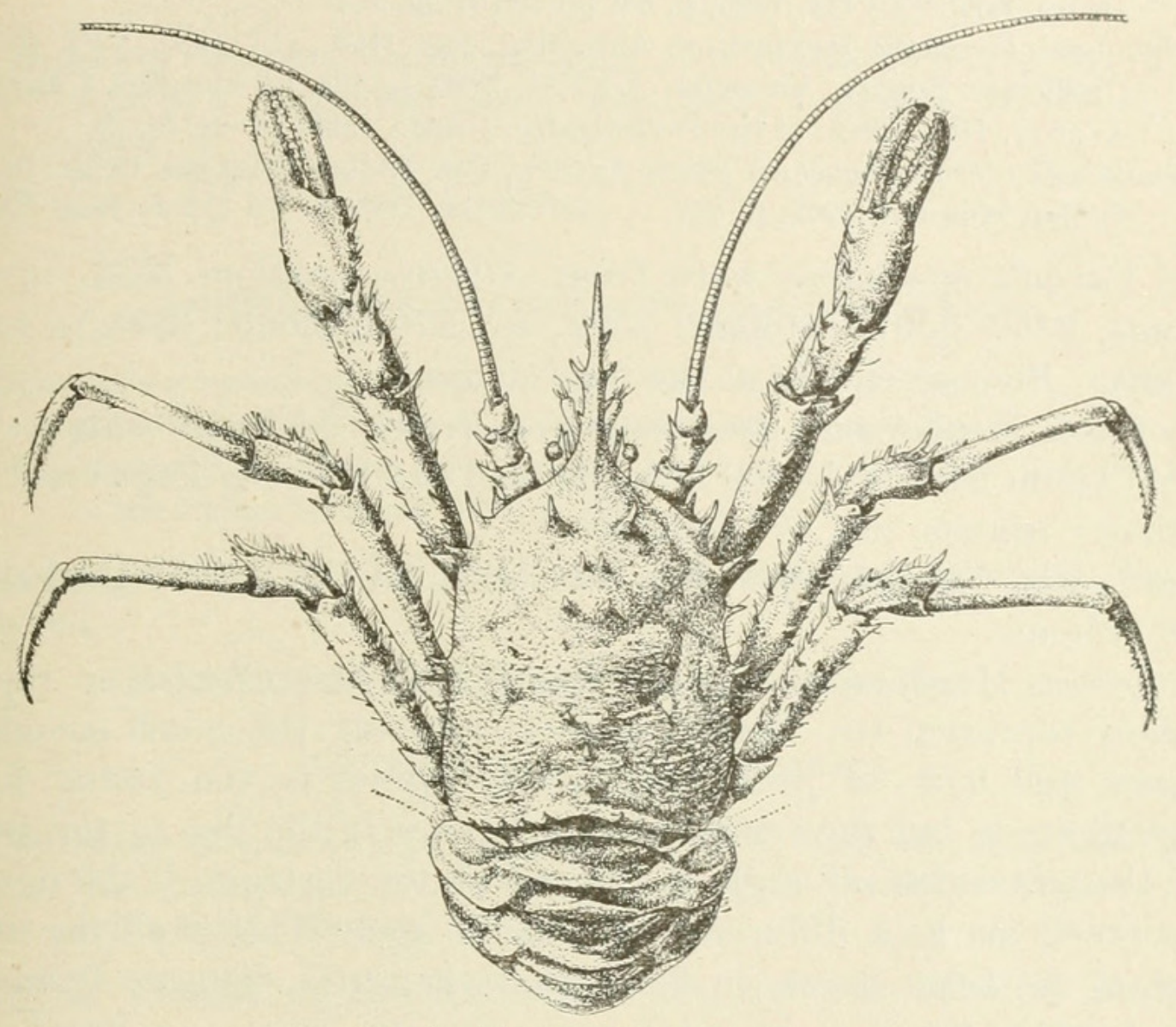

Fig. 47.-MUNidopsis BAIRDII, $\times 1$.

MUNIDOPSIS BERINGANA, new species, see p. 279.

MUNIDOPSIS CARINIPES Faxon.

Munidopsis carinipes FAxon, Bull. Mus. Comp. Zool., XXIV, 1893, p. 189; Mem. Mus. Comp. Zool., XVIII, 1895, p. 97, pl. Xxiv, figs. 1, 1a, 1 b.

Elasmonotus carinipes Alcock, Ann. and Mag. Nat. Hist., (6), 1894, XIII, p. 333. - A. Milne-Edwards and Bouvier, Ann. des Sci. Nat., Zool., (7), XIV, 1893 , p. 281.

Albatross station 3353, in 695 fathoms, off Panama.

\section{MUNIDOPSIS CENTRINA Alcock and Anderson.}

Munidopsis centrina Alcock and Avdenson, Jour. Asiatic Soc. Bengal, LXIII, Pt. 2, 1894, p. 170; Illus. Zool. Investigator, Crust., 1895, pl. xI, fig. 6.

Ihunidopsis (Orophorhynchus) centrina Alcock, Cat. Indian Deep-Sea Crust. in the Indian Museum, 1901, p. 270.

Bay of Bengal, in 1,520 fathoms. 


\section{MUNIDOPSIS CERATOPHTHALMUS Alcock.}

Munidopsis ceratophthalmus Alcock, Cat. Indian Deep-Sea Crust. in the Indian Museum, 1901, p. 271, pl. III, fig. 2.

Andaman Sea, in 480 fathoms.

\section{MUNIDOPSIS CILIATA Wood-Mason.}

Munidopsis ciliata Wood-Mason, Ann. Nat. Hist., 1891, p. 200.-Faxon, Mem. Mus. Comp. Zool., XVIII, 1895, p. 84, pl. xvin, fig. 13.

Munidopsis brevimana Henderson, Ann. Mag. Nat. Hist., (5), 1885, XVI, p. 414; Challenger Report, Anomura, XXVII, 1888, p. 154, pl. xvII, figs. 1 and 2.A lсоск, Illus. Zool. of the Investigator, Crust., 1895, pl. xi, fig. 3.

Munidopsis (Orophorhynchus) ciliata A Lсоск, Cat. Indian Deep-Sea Crust. in the Indian Museum, 1901, p. 267.

Dr. Faxon's specimens were from Albatross stations 3353, in 695 fathoms; 3363, in 978 fathoms; 3392, in 1,270 fathoms; 3393, in 1,020 fathoms. Five specimens at the four stations.

Professor Henderson's specimens were from Challenger stations 191 off the Arrou islands, in 800 fathoms, and 218 between Papua and the Admiralty islands, in 1,070 fathoms.

The Indian Museum specimen was taken in the Bay of Bengal, in 1,310 fathoms.

Professor Henderson's figures 1 and 2 in the Challenger report probably represent two distinct species; not only the much smoother carapace and lack of prominent lateral spines in the young form shown in fig. 2, but the remarkable difference in the line of the front from the antero-lateral angle to the end of the rostrum, if the figures are correct, marks a difference not due to age. This is all the more likely, as the form shown in fig. 2 was taken at a distance from the form shown in fig. 1.

Munidopsis nitida A. Milne-Edwards, from the West India region, as has been pointed out by Dr. Faxon, is a closely related species; six specimens in this museum from station 2140 off Jamaica show a great range in size; five are under $6 \mathrm{~mm}$. in length, and one is $21 \mathrm{~mm}$, , measured from the tip of the rostrum to the posterior margin of the carapace; in all, the lines of the front are much like $M$. citiata, as shown in Professor Henderson's fig. 1, while the carapace is much more like fig. 2.

\section{MUNIDOPSIS CRASSA S. I. Smith.}

Munidopsis crassa S. I. Sмmth, Proc. U. S. Nat. Mus., VII, 1885, p. 494.-A MrineEdwards and E. L. Bouvier, Ann. des Sci. Nat., 1894, (7), XVI, p. 275.

Off the east coast of the United States, Albatross station 2224, in 2,574 fathoms, latitude $36^{\circ}$. 


\section{MUNIDOPSIS CRINITA Faxon.}

Munidopsis crinita Faxon, Bull. Mus. Comp. Zool., XXIV, 1893, p. 185; Mem. Mus. Comp. Zool., XVIII, 1895, p. 92, pl. xx, figs. 3, 3a.

Gralathodes crinitus A. Milne-Edwards and Bouvier, Ann. des Sei. Nat., Zool., (7), XVI, 1894, p. 279.

Albatross station 3384, in 458 fathoms, off Panama. One female.

\section{MUNIDOPSIS CURVIROSTRA Whiteaves.}

Munidopsis curvirostra Whiteaves, Amer. Jour. Sci. and Arts, (3), VII, 1874, p. 212.-S. I. Sмгтн, Bull. Mus. Comp. Zool., X, 1882, p. 21, pl. vin, figs. 2 and 3 .

Off east coast of North America.

\section{MUNIDOPSIS CYLINDROPHTHALMA (Alcock).}

Elasmonotus cylindrophthalmus Aьcock, Ann. Mag. Nat. Hist., (6), XIII, 1894, p. 333; Illus. Zool. Investigator, Crust., 1895, pl. xiII, fig. 4.

Munidopsis (Elasmonotus) cylindrophthalmus A Lсоск, Cat. Indian Deep-Sea Crust. in the Indian Museum, 1901, p. 272.

Andaman Sea, 188-220, 250, and 265 fathoms; Arabian Sea, 406 fathoms.

MUNIDOPSIS CYLINDROPUS, new species, see p. $28 \mathrm{I}$.

\section{MUNIDOPSIS DASYPUS Alcock.}

Munidopsis dasypus Alcock, Ann. and Mag. Nat. Hist., (6), XIII, 1894, p. 329; Illus. Investigator Crust., 1895, pl. xıI, fig. 9; Cat. Indian Deep-Sea Crust. in the Indian Museum, 1901, p. 252.

Bay of Bengal, off the Andamans, 480 and 561 fathoms; Andaman Sea, 498 fathoms; Arabian Sea, 636 fathoms.

\section{MUNIDOPSIS DEBILIS (Henderson).}

Galathopsis debilis Henderson, Ann. and Mag. Nat. Hist., (5), XVI, 1885, p. 417, 1885.

Elasmonotus debilis Henderson, Challenger Report, XXVII, Anomura, 1888, p. 165, pl. xviri, fig. 4 .

Challenger station 173 , depth 315 fathoms. A male specimen. Station 210, among the Philippines, depth 375 fathoms. A malespecimen.

\section{MUNIDOPSIS DEPRESSA Faxon.}

Munidopsis depressa Faxon, Bull. Mus. Comp. Zool., XXIV, 1893, p. 189; Mem. Mus. Comp. Zool., XVIII, 1895, p. 96, pl. xxII, figs. 2-2b.

Albatross station 3425 , in 680 fathoms, off Mexico. One male. 


\section{MUNIDOPSIS EDWARDSII (Wood-Mason).}

Elasmonotus edwardsii Wood-Mason, Ann. Mag. Nat. Hist., 1891, p. 201.

Orophorhynchus edwardsii Mrlne-Edwards and Bouvier, Ann. Sci. Nat., Zool., 1894, (7), XVI, p. 287.

Munidopsis (Orophorhynchus) edwardsii ALсock, Cat. Indian Deep-Sea Crust. in the Indian Museum, 1901, p. 265, pl. III, fig. 4.

Bay of Bengal, in 1,300 and 1,310 fathoms.

\section{MUNIDOPSIS ERINACEA (A. Milne-Edwards).}

Galathodes erinacea A. Milne-Edwards, Bull. Mus. Comp. Zool., VIII, 1880, p. 53. Munidopsis erinacea Henderson, Challenger Repor 149, pl. xvi, fig. 4.-A. Milne-Edwards and Bouvier, Ann. Sci. Nat., Zool., (7), XVI, 1894, p. 275; Mem. Mus. Comp. Zool., XIX, 1897, No. 2, p. 67, pl. vII, figs. 9-12.

Milne-Edwards's specimens were from a number of stations in the West India region in depths that range a little above 400 fathoms (steamer Blalie).

MUNIDOPSIS ESPINIS, new species, see p. 282.

MUNIDOPSIS EXPANSA, new species, see p. 282.

MUNIDOPSIS GILLI, new species, see p. 283.

MUNIDOPSIS GOODRIDGII Alcock and Anderson.

Munidopsis goodridgii Alcock and Anderson, Ann. Mag. Nat. Hist., (7), III, 1899, p. 21; Illus. Investigator Zoology, Crustacea, 1899, pl. xLN, fig. 2; Cat. Indian Deep-Sea Crust. in the Indian Museum, 1901, p. 258.

A single female from off the Travancore coast, 430 fathoms.

\section{MUNIDOPSIS GRANOSA Alcock.}

Munidopsis granosa A Acock, Cat. Indian Deep-Sea Crust. in the Indian Museum, 1901, p. 266 , pl. III, fig. 1.

Bay of Bengal, in 1,520 fathoms.

\section{MUNIDOPSIS HAIMATA Faxon.}

Munidopsis hamata FAxon, Bull. Mus. Comp. Zool., XXIV, 1893, p. 187; Mem. Mus. Comp. Zool., XVIII, 1895, p. 95, pl. XXI, figs. 2-2b.

Albatross stations 3394 and 3395, in 411 and 730 fathoms, Gulf of Panama.

MUNIDOPSIS HASTIFER, new species, see p. 284.

\section{MUNIDOPSIS HEMINGI Alcock and Anderson.}

Munidopsis hemingi Alcock and Anderson, Ann. and Mag. of Nat. Hist., (7), III, 1901, ps 19; Illus. Zool. of the Investigator, Crust., pl. LIv, fig. 4.-A -Acock, Cat. Indian Deep-Sea Crust. in the Indian Museum, 1901, p. 251.

Off the Travancore coast, in 430 fathoms. 


\section{MUNIDOPSIS HENDERSONIANA Faxon.}

Munidopsis hendersoniana FAxon, Bull. Mus. Comp. Zool., XXIV, 1893, p. 190;

Mem. Mus. Comp. Zool., XVIIl, 1895, p. 100, pl. xxiv, figs. 2-2c.

Orophorhynchus hendersoniana Edwards and Bowvier, Ann. Sci. Nat., Zool., (7), XVI, 1894, p. 287.

Albatross station 3393, in 1020 fathoms, Gulf of Panama.

\section{MUNIDOPSIS HYSTRIX Faxon.}

Munidopsis hystrix Faxon, Bull. Mus. Comp. Zool., XXIV, 1893, p. 183; Mem. Mus. Comp. Zool., XVIII, 1895, p. 89, pl. xix, figs. 1, 1 a.

Albatross station 3417, in 493 fathoms. Off Acapulco. Stations 3424 and 3425 in 676 and 680 fathoms, respectively, off Tres Marias Islands.

\section{MUNIDOPSIS INERMIS Faxon.}

Munidopsis inermis Faxon, Bull. Mus. Comp. Zool., XXIV, 1893, p. 191; Mem.

Mus. Com. Zool., X VIII, 1895, p. 98, pl. Xxin, figs. 2, 2a.

Albatrose station $335 t$ in 322 fathoms, Gulf of Panama.

\section{MUNIDOPSIS IRIDIS Alcock and Anderson.}

Munidopsis iridis Alcock and Anderson, Ann. Mag. Nat. Hist., (7), III, 1899, p. 20; Illus. Investigator Zool., Crust., 1899, pl. xLIV, fig. 1.-Alcock, Cat. Indian Deep-Sea Crust. in the Indian Museum, 1901, p. 255.

Fifty-two specimens from off the Travancore coast, 430 fathoms.

\section{MUNIDOPSIS LÆVIGATA (Henderson).}

Galathopsis lievigatus Henderson, Ann. and Mag. Nat. Hist., (5), XVI, 1885, p. 417.

Elasmonotus lavigatus Challenger Report, XXVII, Anomura, p. 164, pl. xviII, fig. 3 .

Challenger station 219, depth 150 fathoms, North of Papua. One specimen.

\section{MUNIDOPSIS LATIFRONS (A. Milne-Edwards).}

Galathodes latifrons A. Milne-Edwards, Bull. Mus. Comp. Zool., VIII, 1880, p. 57.-A. Milne-Edwards and Bouvier, Ann. Sei. Nat., Zool., (7), XVI, 1894, p. 279; Mem. Mus. Comp. Zool., XIX, 1897, No. 2, p. 94, pl. virI, figs. 2,3 .

Blake station 288, in 399 fathoms, Barbados. One specimen.

\section{MUNIDOPSIS LATIROSTRIS Faxon.}

Elasmonotus latifrons Henderson, Ann. and Mag. Nat. Hist., (5), X VI, 1885, p. 416; Challenger Report, XXVII, 1888, Anomura, p. 160, pl. xix, fig. 1.

Orophorhynchus latifrons A. Mrune-Edwards and E. L. Bouvier, Ann. des Sci. Nat. Zool., (7), XVI, 1894, p. 287.

Munidopsis latirostris FAxon, Mem. Mus. Comp. Zool., XVIII, 1895, p. 99.

Albatross station 3381, in 1,772 fathoms, off Malpelo Island. One female. Station 3391, in 153 fathoms, Gulf of Panama. One female. 


\section{MUNIDOPSIS LEVIS (Alcock and Anderson).}

Bathyankyristes levis Alcock and Anderson, Jour. Asiatic Soc. Bengal, LXIII, 1894, Pt. 2, p. 175; Illus. Zool. of the Investigator, Crustacea, pl. Lv, fig. 3.

Munidopsis (Bathyankyristes) levis Ацсоск, Cat. Indian Deep-Sea Crust. in the Indian Museum, 1901, p. 274.

Arabian Sea, in the neighborhood of the Laccadives, 636 fathoms.

\section{MUNIDOPSIS LIVIDA (A. Milne-Edwards).}

Elasmonotus lividus A. Milne-Edwards, in Ed. Perrier, Les Explor. sousmarines, 1886, fig. 242.

Orophorynchus lividus A. Milne-Edwards and E. L. Bouvier, Ann. des Sci. Nat, Zool., (7), XVI, 1894, p. 287, and fig. 12, p. 208; Expéd. Scient. du Travailleur et du Talisman, Brachyures et Anomoures, 1900, p. 343, pl. Iv, fig. 3 ; pl. xxxI, figs. 17-22.

\section{MUNIDOPSIS LONGIMANA (A. Milne-Edwards).}

Elasmonotus longimanus A. Milne-Edwards, Bull. Mus. Comp. Zool., VIII, 1880, p. 60.-A. Milne-Edwards and E. L. Bouvier, Ann. des Sci. Nat., Zool., (7), XVI, 1894, p. 282; Mem. Mus. Comp. Zool., XIX, 1897, No. 2, p. 106, pl. $\mathrm{IX}$, figs. $1-6$.

Blake station 195, in 502 fathoms, Martinique; station 130, in 451 fathoms, Frederickstad; station 221, 423 fathoms, St. Lucia; station 188 , in 372 fathoms, Dominica; station 222 , in 422 fathoms, St. Lucia.

\section{MUNIDOPSIS LONGIROSTRIS Edwards and Bouvier.}

Munidopsis longirostris A. Mrlne-Edwards and E. L. Bouvier, Bull. Mus. Nat. Hist., 1897, p. 365; Résult. des Camp. Scient. de l'Hirondelle et de la Princesse-Alice, Pt. 12, 1899, p. 82; Expéd. Scient. du Travailleur et du Talisman, Crust. Deca., Brachyures et Anomoures, 1900, p. 314, pl. Iv, fig. 4; pl. $\mathrm{xxx}$, figs. 5 to 9 .

\section{MUNIDOPSIS MARGARITA Faxon.}

Munidopsis margarita Faxon, Bull. Mus. Comp. Zool., XXIV, 1893, p. 184; Mem. Mus. Comp. Zool., X VIII, 1895, p. 91, pl. xx, fig. 2.

Albatross station 3404 , in 385 fathoms. Male and female. Near the Galapagos Islands.

\section{MUNIDOPSIS MARGINATA (Henderson).}

Elasmonotus marginatus Henderson, Ann. and Mag. Nat. Hist., (5), X VI, 1885, p. 416; Voyage of the Challenger, XXVII, 1888, Anomura, p. 161, pl. XIX, fig. 2.

Orophorhynchus marginatus A. Milne-Edwards and E. L. Bouvier, Ann. des Sci. Nat., Zool., (7), XVI, 1894, pp. 286, 287.

Challenger station 168, off New Zealand; depth, 1,100 fathoms; bottom, blue mud. 


\section{MUNIDOPSIS MARIONIS (A. Milne-Edwards).}

Galathodes marionis A. Milne-Edwards, Rapport sur la faune sous-marine, p. 17 (note).

Orophorhynchus marionis A. Milne-Enwards and E. L. Bouvier, Ann. des. Sci. Nat., Zool., (7), XVI, 1894, p. 287; Expéd. Scient. du Travailleur et du Talisman, Brachyures et Anomoures, 1900, p. 340, pl. xxxI, figs. 14-16.

European waters.

\section{MUNIDOPSIS MEDIA Edwards and Bouvier.}

Munidopsis media A. Mrlne-Edwards and E. L. Bouvier, Ann. des Sci. Nat., Zool., (7), XVI, 1894, pp. 275, 325; Expéd. Scient. du Travailleur et du Talisman, Brachyures et Anomoures, 1900, p. 325, pl. xxx, fig. 25.

European waters.

\section{MUNIDOPSIS MIERSI (Henderson).}

Elasmonotus miersi Henderson, Ann. and Mag. Nat. Hist., (5), XVI, 1885, p. 416; Voyage of the Challenger, XXVII, 1888, Anomura, p. 162, pl. xix, fig. 3.

Challenger station 173, off Matuku Island, Fiji; depth, 315 fathoms; bottom, coral mud.

\section{MUNIDOPSIS MILLERI Henderson.}

Munidopsis milleri Henderson, Ann. and Mag. Nat. Hist., (5), XVI, 1885, p. 414; Challenger Report, XXVII, 1888, Anomura, p. 155, pl. xvII, fig. 3.

Challenger station 207, depth, 700 fathoms, off Tablas Island, Philippines. A female with ova and two males.

MUNIDOPSIS MINA, new species, see p. 285.

MUNIDOPSIS MODESTA, new species, see p. 286.

MUNIDOPSIS MORESBYI Alcock and Anderson.

Munidopsis moresbyi Alcock and Anderson, Ann. and Mag. Nat. Hist., (7), III, 1899, p. 22; Illus. of the Investigator, Zoology, Crust., 1899, pl. xL, fig. 3.A Lсоск, Cat. Indian Deep-Sea Crustacea, 1901, p. 259.

Arabian Sea, off the Travancore coast, 430 fathoms.

\section{MUNIDOPSIS NITIDA (A. Milne-Edwards).}

Orophorhynchus nitidus A. Milne-Edwards, Bull. Mus. Comp. Zool., VIII, 1880, p. 59.

Orophorhynchus spinosus A. Milne-Edwards, Bull. Mus. Comp. Zool., VIII, 1880, p. 58 .

Munidopsis nitida A. Mrlne-Edwards and E. L. Bouvier, Ann. des Sci. Nat., Zool., (7), XVI, 1894, p. 275; Mem. Mus. Comp. Zool., XIX, 1897, No. 2, p. 74 , pl. vi, figs. 6,7 .

Blake station 163, in 769 fathoms, Guadeloupe. Station 180, in 982 fathoms, Dominica. 
MUNIDOPSIS OPALESCENS, new species, see p. 287.

\section{MUNIDOPSIS ORNATA Faxon.}

Munidopsis ornata Faxon, Bull. Mus. Comp. Zool., XXIV, 1893, p. 186; Mem. Mus. Comp. Zool., XVIII, 1895, p. 87, pl. xx, figs. 1, la.

Albatross station 3404 , in 385 fathoms, Galapagos Islands.

\section{MUNIDOPSIS PALLIDA Alcock.}

Munidopsis subsquamosa var. pallida Alcock, Ann. Mag. Nat. Hist., (6), XIII, 1894, p. 331; Illus. Zool. Investigator, Crustacea, 1895, pl. xIII, fig. 7.

Munidopsis (Orophorhynchus) subsquamosa var. pallida Аьсоск, Cat. Indian DeepSea Crust. in the Indian Museum, 1901, p. 268.

Bay of Bengal in 1,803 fathoms.

\section{MUNIDOPSIS PARFAITI (A. Milne-Edwards).}

Elasmonotus parfaiti A. Milne-Edwards, in Filhol, La Vie au Fond des Mers, 1885, pl. VII.

Orophorhynchus parfaiti A. Mrlne-Edwards and E. L. Bouvier, Ann. des Sci. Nat., Zool., (7), XVI., 1894, p. 287; Expéd. Scient. du Travailleur et du Talisman, Brachyures et Anomoures, 1900, p. 236, pl. III, fig. 1; pl. XxXI, fig. 11-13.

European waters.

\section{MUNIDOPSIS PILOSA Henderson.}

Munidopsis pilosa Henderson, Ann. and Mag. Nat. Hist., (5), XVI, 1885, p. 415; Challenger Report, XXVII, Anomura, 1888, p. 157, pl. xvII, fig. 5.

Challenger station 196; depth 825 fathoms, near Philippine Islands. One male.

\section{MUNIDOPSIS PLATIROSTRIS (A. Milne-Edwards and Bouvier.)}

Orophorhynchus platirostris A. Milne-Edw ARds and Bouvier, Ann. Sei. Nat., Zool., (7), XVI, 1894, p. 287; Mem. Mus. Comp. Zool., XIX, 1897, No. 2, p. 114, pl. Ix, figs. $12-15$; pl. $\mathrm{x}$, fig. 3 .

U. S. Coast Survey steamer Hassler, December 27-30, 1871, 100 fathoms, Barbados.

\section{MUNIDOPSIS POLITA (S. I. Smith).}

Anoplonotus politus S. I. Sмiтh, Proc. U. S. Nat. Mus., VI, 1883, p. 50, pl. II, fig. 1; pl. III, figs. 1-5a.

East North Atlantic.

Dr. Faxon says: ${ }^{a}$ "As the genus Anoplonotus of Smith does not seem to be sufficiently distinct from Elasmonotus, it is here merged, with the latter, in Munidopsis." 


\section{MUNIDOPSIS POSEIDONIA Alcock and Anderson.}

Munidopsis poseidonia Alcock and Anderson, Jour. Asiatic Soc. Bengal, LXIII, Pt. 2, 1894, p. 167; Illus. Zool. Investigator, Crust., pl. XII, fig. 2

Munidopsis (Galathodes) posidonia Aцcock, Cat. Indian Deep-Sea Crust. in the Indian Museum, 1901, p. 263.

Bay of Bengal, off Madras coast, 210 fathoms.

\section{MUNIDOPSIS QUADRATA Faxon.}

Munidopsis quadrata FAxon, Bull. Mus. Comp. Zool., XXIV, 1893, p. 188; Mem.

Mus. Comp. Zool., 1895, p. 97, pl. xxır, figs. 1, 1c.

Elasmonotus quadratus A. Milne-Edwards and Bouvier, Ann. Sci. Nat., Zool., (7), XVI, 1894, p. 282.

Albatross station 3424, in 676 fathoms, and station 3425 in 680 fathoms, Tres Marias Islands.

\section{MUNIDOPSIS REGIA Alcock and Anderson.}

Munidopsis regia Alcock and Anderson, Jour. Asiatic Soc. Bengal, LXIII, Pt. 2, 1894, p. 168; Illus. Zool. Investigator, Crust., 1895, pl. xı, fig. 1; Cat. Indian Deep-Sea Crust. in the Indian Museum, 1901, p. 261.

Arabian Sea, off Colombo, 142-400 fathoms, Andaman Sea, 405 fathoms.

\section{MUNIDOPSIS REYNOLDSI (A. Milne-Edwards).}

Galathodes reynoldsi A. Milne-Edwards, Bull. Mus. Comp. Zool., VIII, 1880, p. 56.

Munidopsis reynoldsi A. Mrlne-Enwands and Bouvier, Ann. Sei. Nat., Zool., (7), XVI, 1894, p. 275; Mem. Mus. Comp. Zool., XIX, 1897, No. 2, p. 80, pl. vi, figs. $1-5$.

Blake station 138 in 2,376 fathoms, Ham's Bluff.

\section{MUNIDOPSIS ROBUSTA (A. Milne-Edwards).}

Galathodes robustus A. Milne-Edwards, Bull. Mus. Comp. Zool., VIII, 1880, p. 54. Munidopsis robusta A. Mrlne-Edwards and Bouvier, Ann. Sci. Nat., (7), XVI, 1894, p. 275; Mem. Mus. Comp. Zool., XIX, 1897, No. 2, p. 69, pl. vi, figs. 15-20; pl. vII, fig. 1 .

Blake station 2.58 in 159 fathoms, Grenada.

\section{MUNIDOPSIS SCABRA Faxon.}

Iunidopsis scabra Faxon, Bull. Mus. Comp. Zool., XXIV, 1893, p. 186; Mem. Mus. Comp. Zool., XVIII, 1895, p. 93, pl. xxI, figs. 1, 1a.

Albatross station 3424 in 676 fathoms, and station 3425 in 680 fathoms, Tres Marias Islands.

\section{MUNIDOPSIS SCOBINA Alcock.}

Munidopsis scobina Alcock, Ann. Mag. Nat. Hist., (6), XIII, 1894, p. 330; Illus. Investigator, Crust., 1895, pl. xıI, fig. 1; Cat. Indian Deep-Sea Crust. Indian Museum, 1901, p. 254.

Northein end of the Bay of Bengal, 193, 240, 272, 405-285, and 409 fathoms. 
MUNIDOPSIS SERICEA Faxon.

Munidopsis sericea Faxon, Bull. Mus. Comp. Zool., XXIV, 1893, p. 184; Mem. Mus. Comp. Zool., XVIII, 1895, p. 90, pl. xix, figs. 3, 3a.

Albatross station 3394 in 511 fathoms, Gulf of Panama.

\section{MUNIDOPSIS SERRATIFRONS (A. Milne-Edwards).}

Galathodes serratifrons A. Milne-Edwards, Bull. Mus. Comp. Zool., VIII, No. 1, 1880 , p. 55.

Munidopsis serratifrons Henderson, Challenger Report, XXVII, 1888, Anomura, p. 149, pl. xvi, fig. 3.- A. Milne-Edwards and E. L. Bouvier, Mem. Mus. Comp. Zool., XIX, 1897, p. 78, pl. vi, fig. 12-14.

Blate station 185 in 333 fathoms, Dominica; Challenger station 56 , off Bermuda, in 1,075 fathoms; Albatross station 2154, in 310 fathoms, off Habana, Cuba.

\section{MUNIDOPSIS SHARRERI (A. Milne-Edwards).}

Orophorhynchus sharreri A. Minne-Enwands, Bull. Mus. Comp. Zool., VIII, 1880, p. 59.

Munidopsis sharreri A. Milne-Edwards and E. L. Bouvier, Ann. des Sci. Nat., Zool., (7), XVI, 1894, p. 275; Mem. Mus. Comp. Zool., XIX, 1897, No. 2, p. 71 , pl. vir, fig. $2-5$.

Santa Cruz, in 248 fathoms, steamer Blake.

\section{MUNIDOPSIS SIGSBEI (A. Milne-Edwards).}

Galathodes sigsbei A. Minne-Edwards, Bull. Mus. Comp. Zool., VIII, 1880, p. 56. Munidopsis sigsbei Henderson, Challenger Report, XXVII, 1888, Anomura, p. 150, pl. xvili, fig. 2.-A. Milne-Edwards and Bouvier, Ann. des Sei. Nat., (7), XVI, 1894, p. 275; Mem. Mus. Comp. Zool., XIX, 1897, No. 2, p. 83, pl. v, fig. 8-26.

Blake station 200 in 472 fathoms, Martinique.

\section{MUNIDOPSIS SIMILIS S. I. Smith.}

Munidopsis similis S. I. Smith, Proc. U. S. Nat. Mus., VII, 1885, p. 496.-A. Milne-Edwards and E. L. Bouvier, Ann. des Sci. Nat., Zool., (7), XVI, 1894 , p. 275.

Off the east coast of the United States: Albatross station 2192, latitude $39^{\circ}$, in 1,060 fathoms.

\section{MUNIDOPSIS SIMPLEX (A. Milne-Edwards).}

Galatnodes simplex A. Milne-Edwards, Bull. Mus. Comp. Zool., VIII, 1880, p. 56. Munidopsis simplex A. Milne-Edwards and E. L. Bouvier, Ann. des Sci. Nat., Zool., (7), XVI, 1894, p. 275; Mem. Mus. Comp. Zool., XIX, 1897, No. 2. p. 89 , pl. v, figs. $2-7$.

Guadeloupe, Martinique, St. Vincent, 333 to 982 fathoms. 


\section{MUNIDOPSIS SPINIFER A. Milne-Edwards.}

Munidopsis spinifer A. Milne-Edwards, Bull. Mus. Comp. Zool., VIII, 1880, p. 54.-A. Milne-Edwards and Bouvier, Ann. des Sci. Nat. Zool., (7), XVI, 1894, p. 275; Mem. Mus. Comp. Zool., XIX, 1897, No. 2, p. 64, pl. vir, figs., $6-8$.

Blake, station 146, in 245 fathoms; St. Kitts. Station 100 in 250 to 400 fathoms.

\section{MUNIDOPSIS SPINOCULATA (A. Milne-Edwards).}

Orophorhynchus spinoculatus A. Minne-Edwards, Bull. Mus. Comp. Zool., VIII, 1880 , p. 59.

Munidopsis spinoculata A. Milne-Edwards and E. L. Bouvier, Ann. des Sci. Nat., Zool., (7), XVז, 1894, p. 275; Mem. Mus. Comp. Zool., XIX, 1897, No. 2, p. 75 , pl. vi, figs. $8-11$.

Dominica, in 824 fathoms.

\section{MUNIDOPSIS SQUAMOSA (A. Milne-Edwards).}

Orophorhynchus squamosus A. Milne-Edwards, Bull. Mus. Comp. Zool., VIII, 1880 , p. 58.

Elasmonotus squamosus A. Milne-Edwards and E. L. Bouvier, Ann. des Sci. Nat., Zool., (7), XVI, 1894, p. 282; Mem. Mus. Comp. Zool, XIX, 1897, No. 2, p. 99, pl. vin, figs. 4-6.

St. Lucia, in 116 fathoms.

\section{MUNIDOPSIS STYLIROSTRIS Wood-Mason.}

Munidopsis stylirostris Wood-Mason, Ann. Mag. Nat. Hist., (6), 1891, p. 201.Alcock, Ann. Mag. Nat. Hist., (6), XIII, 1894, p. 328; Illus. Investigator, Zool., Crust., 1895, pl. xıI, fig. 6 .

Arabian Sea, in 738, 824, 836, and 947 fathoms.

\section{MUNIDOPSIS SUBSQUAMOSA Henderson.}

Munidopsis subsquamosa Hendersox, Ann. and Mag. Nat. Hist., (5), XVI, 1885, p. 414; Challenger Report, XXVII, Anomura, 1888, p. 152, pl. xvII, fig. 4.A rcock, Cat. Indian Deep-Sea Crust. in Indian Museum, 1901, p. 256; Mem. Mus. Comp. Zool., XVIII, 1895, p. 85.

Challenger, station 237, in 1875 fathoms, off Yokohama.

MUNIDOPSIS TALISMANI Edwards and Bouvier.

Munidopsis talismani A. Milne-Edwards and E. L. Bouvier, Ann. des Sci. Nat., Zool., (7), XVI, 1894, p. 275; Expéd. Scient. du Travailleur et du Talisman, Brachyures and Anomoures, 1894, p. 316, pl. xxx, figs. 11-14.

European waters.

\section{MUNIDOPSIS TANNERI Faxon.}

Munidopsis tanneri Faxon, Bull. Mus. Comp. Zool., XXIV, 1893, p. 187; Mem. Mus. Comp. Zool., XVIII, 1895, p. 94, pl. XxIr, figs. 1, 1a.

Albatross station 3396, in 259 fathoms, gulf of Panama; station 3397, in 85 fathoms, Gulf of Panama. 


\section{MUNIDOPSIS TAURULUS Ortmann.}

Munidopsis taurulus Orтмan, Zool. Jahrb., System, 1892, p. 256, pl. II, fig. 13. MUNIDOPSIS TENAX Alcock.

Bathyankyristes spinosus Alcock, Jour. Asiatic Soc. Bengal, LXIII, 1894, Pt. 2, p. 174, pl. Ix, fig. 2; Illus. Zool. Investigator, Crustacea, pl. Lv, fig. 2.

Munidopsis (Bathyankyristes) tenax Alcock, Cat. Indian Deep-Sea Crust. Indian Nuseum, 1901, p. 273.

Andaman Sea, off Ross Island, 265 fathoms.

MUNIDOPSIS TENUIROSTRIS, new species, see p. 289.

MUNIDOPSIS TOWNSENDI, new species, see p. 290.

\section{MUNIDOPSIS TRACHYPUS Alcock and Anderson.}

Munidopsis trachypus Alcock and Anderson, Jour. Asiatic Soc. Bengal, LXIII, 1894, Pt. 2, p. 169; Illus. Zool. Investigator, Crust., 1895, pl. xI, fig. 2.A Lcock, Cat. Indian Deep-Sea Crust. Indian Museum, 1901, p. 262.

Arabian Sea, north of the Laccadives, 636 fathoms.

\section{MUNIDOPSIS TRI $A$ NA Alcock and Anderson.}

Munidopsis triæna Alcock and Anderson, Jour. Asiatic Soc. Bengal, LXIII, 1894,

Pt. 2, p. 168; Illus. Investigator Zool_Crust., 1895, pl. xi, fig. 5.

Munidopsis (Galathodes) triæna A цсоск, Cat. Indian Deep-Sea Crust. Indian Museum, 1901, p. 261.

Bay of Bengal, off the Andaman coast, in $240-290$ and 375 fathoms.

\section{MUNIDOPSIS TRIDENS (A. Milne-Edwards).}

Galathodes tridens A. Milne-Edwards, Bull. Mus. Comp. Zool., VIII, 1880, p. 57.-A. Milne-Edwards and Bouvier, Ann. des Sci. Nat., (7), X VI, 1894, p. 279; Mem. Mus. Comp. Zool., XIX, 1897, No. 2, p. 96, pl. vir, figs. 13-15; pl. viII, fig. 1.

Blake station 148, in 208 fathoms, St. Kitts.

\section{MUNIDOPSIS TRINENTATA (Esmark).}

Galathea tridentata Esmark, Forhdl. Skandin. Naturf., 7 Möde, (1856), 1857, p. 157. Galathodes rosaceus A. Milne-Edwards, Rec. de Fig. de Crust., 1883, pl. xiII, fig. 1.

Galathodes tridentatus A. Minne-Edwards and E. L. Bouvier, Crust. Hirondelle et Princesse-Alice, Monaco, 1899, p. 83.

? Munidopsis rosacea Alcock and Anderson, Ann. Mag. Nat. Hist., 1899, (7), III, p. 19.

Munidopsis (Galathodes) ? tridentata A Lсоск, Cat. Indian Deep-Sea Crust., Indian Museum, 1901, p. 264.

"Two hundred and thirty-seven specimens were taken in the Arabian Sea, off the Travancore coast, in 430 fathoms." 


\section{MUNIDOPSIS TRIFIDA Henderson.}

Munidopsis trifida Henderson, Ann. Mag. Nat. Hist., (5), XVI, 1885, p. 415; Challenger Report, XXVII, 1888, Anomura, p. 156, pl. xvi, fig. 2.

Galathodes trifidus A. Milne-Edwards and Bouvier, Ann. des Sci. Nat., Zool,, (7), X VI, 1894, p. 279.

Challenger station 310 , in 400 fathoms, Sarmiento Channel, Patagonia.

Mr. Henderson describes his specimens as having "a few short hairs scattered over the surface." This is true of the specimens in this museum, one from Albatross station 2781, in 348 fathoms, and one from station 2785 in 449 fathoms. Both stations are off the west coast of Patagonia at no great distance from the type locality of $M$. trifida.

Alcock and Anderson ${ }^{a}$ have referred to $M$. trifida specimens from the "Arabian Sea, north of the Laccadives, 636 fathoms; Bay of Bengal, off the Andamans, 480 fathoms; Andaman Sea, 498 fathoms." Contrary to the character of the type and topotypes, these specimens are described as tomentose. "Body and appendages tomentose. Carapace when denuded transversely rugose, especially posterolaterally.'

It does not seem at all. improbable that specimens from localities so widely separated and differing so much in the amount of hair (the one being naked and the other clothed) would show additional diverse characters when placed side by side; however, in the absence of intergrading specimens, this character alone renders the forms specifically distinct. I therefore propose that the form from the Indian Seas be known as Munidopsis tomentosa.

MUNIDOPSIS UNGUIFERA Alcock and Anderson.

Munidopsis unguifera Alcock and Anderson, Jour. Asiatic Soc. Bengal, LXIII, Pt. 2, 1894, p. 172; Illus. Investigator Zool., Crust., 1895, pl. xI, fig. 4.Alcock, Cat. Indian Deep-Sea Crust., 1901, p. 253.

Bay of Bengal, in 145-250 fathoms, Andaman Sea, in 490 fathoms.

MUNIDOPSIS VAILLANTI (A. Milne-Edwards).

Elasmonotus vaillanti A. Milne-Edwards, Comp. Rend. Acad. des Sci., p. 932, Dec., 1881.-A. Milne-Edwards and E. L. Bouvier, Ann. des Sci. Nat., Zool., (7), X VI, 1894, p. 282; Expéd. Scient. du Travailleur et du Talisman, Brachyures et Anomoures, 1900, p. 333, pl. xxxI, fig. 8-10.

MUNIDOPSIS VERRILLI, new species, see p. $29 \mathrm{r}$.

MUNIDOPSIS VICINA Faxon.

Munidopsis vicina Faxon, Bull. Mus. Comp. Zool., XXIV, 1893, p. 181; Mem. Mus. Comp. Zool., X VIII, 1895, p. 85, pl. xvmi, figs. 2-2a.

Albatross station 3360 , in 1,670 fathoms, Gulf of Panama; station 3382 in 1,793 fathoms, Gulf of Panama. 


\section{MUNIDOPSIS VILLOSA Faxon.}

Munidopsis villosa FAxon, Bull. Mus. Comp. Zool., XXIV, 1893, p. 182; Mem. Mus. Comp. Zool., XVIII, 1895, p. 86, pl. xix, fig 2. Albatross station 3394, in 511 fathoms, Gulf of Panama.

\section{MUNIDOPSIS WARDENI Anderson.}

Munidopsis wardeni Anderson, Jour. Asiatic Soc. Bengal, LXV, Pt. 2, 1896, p. 99; Illus. Investigator Zool., Crust., pl. Lv, fig. 1.-Ацсоск, Cat. Indian Deep-Sea Crust, 1901, p. 257.

Arabian Sea, in 406, 457-589, 459, and 531 fathoms; Bay of Bengal, in 480 and $594-225$ fathoms.

\section{UROPTYCHUS Henderson.}

Diptychus A. Milne-Edwards, Bull. Mus. Comp. Zool., VIII, 1880, p. 61 (name preoccupied).

Uroptychus (new name) Hendenson, Report Voyage Challenger, 1888, p. 173.

\section{UROPTYCHUS ARMATUS (A. Milne-Edwards).}

Diptychus armatus A. Milne-Edwards, Bull. Mus. Comp. Zool., VIII, 1880, p. 59.-A. Milne-Edwards and E. L. Bouvier, Ann. des Sci. Nat., Zool., (7), X VI, 1894, p. 306.-Mem. Mus. Comp. Zool., XIX, No. 2, p. 132, pl. xI, fig. 3 ; pl. xII, figs. 8 and 9.

Blake station 241; depth, 163 fathoms; Cariacou.

\section{UROPTYCHUS AUSTRALIS (Henderson).}

Diptychus australis Henderson, Ann. Mag. Nat. Hist., (5), XVI, 1885, p. 420.

Uroptychus australis Hendenson, Challenger Report, XXVII, 1888, Anomura, p. 179, pl. Xxi, fig. 4.

Challenger station 171, near the Kermadec Islands; depth, 600 fathoms.

\section{UROPTYCHUS AUSTRALIS var. INDICUS Alcock.}

Uroptychus australis var. indicus Alcock, Cat. Indian Deep-Sea Crust. Indian Museum, 1901, p. 284.

Arabian Sea, off Cape Comorin, 459 fathoms; Bay of Bengal, off Ceylon, 805 fathoms.

\section{UROPTYCHUS BACILLIMANUS Alcock and Anderson.}

Uroptychus bacillimanus Alcock and Anderson, Ann. Mag. Nat. Hist., (7), III, 1899, p. 25; Illus. Zool. Investigator, Crust., 1899, pl. xLv, fig. 3.-ALcock, Cat. Indian Deep-Sea Crust. in Indian Museum, 1901, p. 285.

A young male and female from off the Travancore coast, 430 fathoms, and an egg-laden female from off Ceylon, 320-296 fathoms. 


\section{UROPTYCHUS BELLUS Faxon.}

Uroptychus bellus Faxon, Bull. Mus. Comp. Zool., XXIV, 1893, p. 193; Mem. Mus. Comp. Zool., 1895, p. 102, pl. xxvi, figs. 2-2b.

Diptychus bellus A. Milne-Edwards and Bouvier, Ann. des Sci. Nat., Zool., (7), XVI, 1894, p. 306.

Albatross station 3354 , in 322 fathoms. Station 3355, 182 fathoms, off Panama.

UROPTYCHUS BREVIS, new species, see p. 292.

UROPTYCHUS CAPILLATUS, new species, see p. 293.

UROPTYCHUS FUSIMANUS Alcock and Anderson.

Uroptychus fusimanus Alcock and Anderson, Ann. Mag. Nat. Hist., (7), III, 1899, p. 26; Illus. Zool. Investigator, Crust., 1899, pl. xLIv, fig. 4.-Alcock,

Cat. Indian Deep-Sea Crust. Indian Museum, 1901, p. 283.

Seven specimens from off the Travancore coast, in 430 fathoms.

\section{UROPTYCHUS GRACILIMANUS (Henderson).}

Diptychus gracilimanus Henderson, Ann. Mag. Nat. Hist., (5), XVI, 1885, p. 420.

Uroptychus gracilimanus Henderson, Challenger Report, XXVII, 1888, Anomura, p. 181 , pl. XxI, fig. 5 .

Challenger station 164B, off Port Jackson; depth, 410 fathoms.

UROPTYCHUS GRANULATUS, new species, see p. 293.

UROPTYCHUS INSIGNIS (Henderson).

Diptychus insignis Henderson, Ann. Mag. Nat. Hist., (5), XVI, 1885, p. 419.

Uroptychus insignis Henderson, Challenger Report, Anomura, XXVII, 1888, p. 175, pl. xxI, fig. 1.

Challenger station $145 \mathrm{~A}$, off Prince Edwards Island; depth, 310 fathoms.

\section{UROPTYCHUS INTERMEDIUS (A. Milne-Edwards).}

Diptychus intermedius A. Milne-Edwards, Bull. Mus. Comp. Zool., VIII, 1880, p. 63; Mem. Mus. Comp. Zool., XIX, No. 2, 1897, p. 127, pl. XII, fig. 1-7. Blake station 241; depth, 163 fathoms; Cariacou.

UROPTYCHUS JAMAICENSIS, new species, see p. 29

UROPTYCHUS MINUTUS, new species, see p. 296.

\section{UROPTYCHUS NIGRICAPILLIS Alcock.}

Uroptychus nigricapillis Alcock, Cat. Indian Deep-Sea Crust. Indian Museum, 1901, p. 283, pl. III, fig. 3.

Andaman Sea, 669 fathoms.

Proc. N. M. vol. xxvi-02-23 


\section{UROPTYCHUS NITIDUS (A. Milne-Edwards).}

Diptychus nitidus A. Mrlne-Edwards, Bull. Mus. Comp. Zool., VIII, 1880, p. 62.A. Milne-Edwards and Bouvier, Ann. des Sci. Nat., Zool., (7), XVI, 1894, p. 306; Mem. Mus. Comp. Zool., XIX, 1897, p. 134, pl. xI, figs. 21, 22; pl. XII, figs. $10-16$.

Uroptychus nitidus Hendenson, Challenger Report, Anomura, XXVII, 1888, p. 174, pl. xxı, fig. 6.

Blake station 137; depth, 625 fathoms; Frederickstadt. Station 227 ; depth, 273 fathoms.

\section{UROPTYCHUS NITIDUS var. CONCOLOR (Edwards \& Bouvier).}

Diptychus nitidus var. concolor A. Milne-Edwards and Bouvier, Ann. des Sci. Nat., Zool., (7), XVI, 1894, p. 306; Résult. des camp. scient. de l'Hirondelle (supplément) et de la Princesse-Alice, Pt. XIII, p. 87, pl. I, fig. 2.—Edwards and Bouvier, Expéd. Sci. du Travailleur et du Talisman, 1900, p. 360, pl. Iv, pl. xxxII, fig. 15-19.

Uroptychus nitidus var. concolor M. Caulliery, Result. de la camp. du Caudan, II, p. 393.

\section{UROPTYCHUS OCCIDENTALIS Faxon.}

Uroptychus nitidus occidentalis FAxon, Bull. Mus. Comp. Zool., XXIV, 1893, p. 192; Mem. Mus. Comp. Zool., XVIII, 1895, p. 101, pl. xxvi, figs. 1, 1a.

Diptychus nitidus var. occidentalis Mrlne-Edwards and Bouvier, Ann. des Sci. Nat., Zool., (7), XVI, 1894, p. 306.

Albatross, station 3384; depth, 458 fathoms; off Panama. See Uroptychus occidentalis, Key, p. 292.

\section{UROPTYCHUS PARVULUS (Henderson).}

Diptychus parvulus Henderson, Ann. Mag. Nat. Hist., (5), XVI, 1885, p. 420.

Uroptychus parvulus Henderson, Challenger Report, XXVII, 1888, p. 177, pl. xxI, fig. 3.

Challenger station 310; Sarmiento Channel, Patagonia; depth, 400 fathoms.

\section{UROPTYCHUS POLITUS (Henderson).}

Diptychus politus Henderson, Ann. Mag. Nat. Hist., (5), XVI, 1885, p. 420.

Uroptychus politus Henderson, Challenger Report, Anomura, XXVII, 1888, p. 178, pl. vi, fig. 2.

Challenger station 171, near the Kermadec Islands; depth, 600 fathoms.

UROPTYCHUS PRINCEPS, new species, see p. 296.

\section{UROPTYCHUS PUBESCENS Faxon.}

Uroptychus pubescens FAxon, Bull. Mus. Comp. Zool., XXIV, 1893, p. 192; Mem.

Mus. Comp. Zool., XVIII, 1895, p. 101, pl. xxvi, figs. 3, a, b.

Diptychus pubescens A. Milne-Edwards and Bouvier, Ann. Sci. Nat., Zool., (7),

XVI, 1894, p. 306.

Albatross stations 3354, in 322 fathoms, and 3355, in 182 fathoms, off Panama. 


\section{UROPTYCHUS RUBRO-VITTATUS (A. Milne-Edwards.}

Diptychus rubro-vittatus A. Milne-Edwards, Ann. des Sci. Nat., Zool., (7), XVI, 1894, p. 306; Expéd. Sci. du Travailleur et du Talisman, 1900, p. 356, pl. xxxir, fig. 6-14.-M. Caullery, Résult. de la camp. du Caudan, Pt. 2, 1896, p. 393.

\section{UROPTYCHUS RUGOSUS (A. Milne-Edwards).}

Diptychus rugosus A. Milne-Edwands, Bull. Mus. Comp. Zool., VIII, 1880, p. 63.-A. Milne-Edwards and E. L. Bouvier, Mem. Mus. Comp. Zool., XIX, 1897, No. 2, p. 124, pl. xI, figs. 4-14.

West India region, in 95 to 240 fathoms.

UROPTYCHUS SCAMBUS, new species, see p. 297.

UROPTYCHUS SCANDENS, new species, see p. 298.

UROPTYCHUS SPINIGER, new species, see p. 298.

UROPTYCHUS SPINIMARGINATUS (Henderson).

Diptychus spinimarginatus Henderson, Ann. Mag. Nat. Hist., (5), XVI, 1885, p. 419.

Uroptychus spinimarginatus Henderson, Challenger Report, Anomura, XXVII, 1888, p. 176, pl. xxI, fig. 2.

Challenger station 170, off Kermadec Islands; depth, 520 fathoms.

UROPTYCHUS SPINOSUS (A. Milne-Edwards and E. L. Bouvier).

Diptychus spinosus A. Milne-Edwarus and Bouvier, Ann. des. Sci. Nat., Zool., (7), XVI, 1894, p. 306; Mem. Mus. Comp. Zool., XIX, 1897, No. 2, p. 129, pl. $\mathrm{XI}$, figs. $15-20$.

West India region.

\section{UROPTYCHUS TRIDENTATUS (Henderson).}

Diptychus tridentatus Henderson, Ann. Mag. Nat. Hist., (5), XVI, 1885, p. 421. Uroptychus tridentatus Hendenson, Challenger Report, XXVII, 1888, p. 181, pl. vi, fig. 1.

Amboina, depth?

\section{UROPTYCHUS UNCIFER (A. Milne-Edwards).}

Diptychus uncifer A. Milne-Edwards, Bull. Mus. Comp. Zool., VIII, 1880, p. 63.A. Milne-Edwards and Bouvier, Ann. Sci. Nat., Zool.,(7), XVI, 1894, p. 306; Mem. Mus. Comp. Zool., XIX, 1897, No. 2, p. 140, pl. XI, figs. 1 and 2; pl. xII, figs. 17-29.

Blake station 232; depth, 88 fathoms; St. Vincent. Station 273; depth, 103 fathoms; Barbados. Station 269; depth, 124 fathoms; St. Vincent.

PTYCHOGASTER A. Milne-Edwards.

Ptychogaster A. Milne-Edwands, Bull. Mus. Comp. Zool., VIII, 1880, p. 63. 


\section{PTYCHOGASTER FORMOSUS A. Milne-Edwards.}

Ptychogaster formosus A. Milne-Edwards and E. L. Bouvier, Ann. des Sci. Nat,, Zool., (7), XVI, 1894, p. 205, fig. 9; p. 216, fig. 20.-A. Milne-Edwards and E. L. Bouvier, Expd. Scient. du Travailleur et du Talisman, Crust. Decap. Brachyures et Anomoures, 1900, p. 350, pl. III, fig. 2; pl. xxxII, fig. 1-5. See for Synonymy.

\section{PTYCHOGASTER HENDERSONI Alcock and Anderson.}

Ptychogaster hendersoni Alcock and Andenson, Ann. Mag. Nat. Hist., Jan., 1899, p. 23.-A Асоск, Cat. Indian deep-sea Crust. Indian Museum, 1901, p. 280; Illus. Zool. Investigator, Crust., pl. xLv, fig. 2.

\section{PTYCHOGASTER INVESTIGATORIS Alcock and Anderson.}

Ptychogaster investigatoris Alcock and Anderson, Ann. Mag. Nat. Hist., Jan., 1899, p. 24; Illus. Zool. Investigator, Crust., pl. xLv, fig. 1.-Alcock, Cat. Indian deep-sea Crust. Indian Museum, 1901, p. 281.

\section{PTYCHOGASTER LAEIS Henderson.}

Ptychogaster lrexis Hendenson, Ann. Mag. Nat. Hist., (5), XVI, 1885, p. 418; Challenger Rept., XXVII, 1888, Anomura, p. 172, pl. xx, fig. 3.-A. MilneEdwards and E. L. Bouvier, Ann. des Sci. Nat., Zool., (7), XVI, 1894, p. 302.

\section{PTYCHOGASTER MILNE-EDWARDSI Henderson.}

Ptychogaster milne-edwardsi Henderson, Narr. Chall. Exp., I, 1885, p. 900, fig. 330; Ann. Mag. Nat. Hist., (5) , 1885, XVI, p. 418; Rep. Anomura Challenger Ex., XXVII, 1888, p. 171, pl. xx, fig. 2.

\section{PTYCHOGASTER SPINIFER A. Milne-Edwards.}

Ptychogaster spinifer A. Milne-Edwands, Bull. Mus. Comp. Zool., VIII, 1880, p. 64.-A. Minne-Edwards and E. L. Bouvier, Ann. des Sci. Nat., Zool., (7), XVI, 1894, p. 302; Mem. Mus. Comp. Zool., XIX, No. 2, 1897, p. 118; pl. IX, fig. $16-22$; pl. $x$, fig. 4-16.

\section{EUMUNIDA S. I. Smith.}

\section{EUMUNIDA PICTA S. I. Smith.}

Eumunida picta S. I. Sмгтн, Proc. U. S. Nat. Mus., VI, 1883, p. 44, pl. II, fig. 2; pl. III, fig. 6-10; pl. Iv, fig. 1-3; Report Com. Fish and Fisheries, p. 46 (1885), 1886.-A. Milne-Edwards and E. L. Bouvier, Ann. des Sci. Nat., Zool., (7), XVI, 1894, pp. 211, 230, fig. 14; Expéd. Sci. du Travailleur et du Talisman, Brachyures et Anomoures, p. 364, 1900, pl. v, fig. 1; pl. xxviII, fig. 26 ; pl. хxхII, figs. $20-24$.

\section{EUMUNIDA SMITHII Henderson.}

Eumunida smithii Henderson, Ann. Mag. Nat. Hist., (5), XVI, 1885, p. 413; Voyage of the Challenger, Report on the Anomura, XVII, 1888, p. 169, pl. $\mathrm{xv}$, fig. 5 . 


\section{$2 \mathrm{BHL}$ Biodiversity Heritage Library}

Benedict, James E. 1902. "Description of a new genus and forty-six new species of Crustaceans of the family Galatheidae, with a list of the known marine species." Proceedings of the United States National Museum 26, 243-334. https://doi.org/10.5479/si.00963801.26-1311.243.

View This Item Online: https://www.biodiversitylibrary.org/item/32571

DOI: https://doi.org/10.5479/si.00963801.26-1311.243

Permalink: https://www.biodiversitylibrary.org/partpdf/9428

\section{Holding Institution}

Smithsonian Libraries

\section{Sponsored by}

Smithsonian

\section{Copyright \& Reuse}

Copyright Status: NOT_IN_COPYRIGHT

This document was created from content at the Biodiversity Heritage Library, the world's largest open access digital library for biodiversity literature and archives. Visit BHL at https://www.biodiversitylibrary.org. 